\title{
Constitutional Choices: Legal Feminism and the Historical Dynamics of Change
}

\author{
Serena Mayeri $\dagger$
}

TABLE OF CONTENTS

Introduction.

I. Building a Strategy for Constitutional Change: The ERA, the Fourteenth Amendment, and Constitutional Roads Not Taken

A. "We May Escape From Our Dilemma": Pauli Murray and the Resurrection of the Fourteenth Amendment, 1962-63.

B. Title VII's Sex Amendment and the Creation of a New Civil Rights Constituency, 1963-65

1. Protecting the "White Christian Woman of United States Origin".

2. "Today 1t ls the Negro Women Who Will Win for All of Us Equal Rights": Title V1I's Partial Triumph and the Retreat from Feminist Racialism

C. "We Differ Not So Much in Our Objectives as in Our Strategy": The Promise of the Fourteenth Amendment and the Articulation of the Dual Strategy, 1965-66.

1. Feminists' Great White Hope

2. A "Philosophy of Continuity and 1nclusiveness"

3. "An Integral Relation": The Unrealized Promise of the Jury Exclusion 1ssue

Copyright (C) 2004 California Law Review, Inc. California Law Review, Inc. (CLR) is a California nonprofit corporation. CLR and the authors are solely responsible for the content of their publications.

$\dagger \quad$ Law clerk to the Honorable Guido Calabresi, U.S. Court of Appeals for the Second Circuit; Ph.D. Candidate, Department of History, Yale University; J.D., Yale Law School, 2001; A.B., Harvard College, 1997. 1 would like to thank Bruce Ackerman, Guido Calabresi, Nancy Cott, Deborah Dinner, Ruth Emerson, Bill Eskridge, Maame Ewusi-Mensah, Glenda Gilmore, Bob Gordon, Michael Jo, Laura Kalman, Amy Kapczynski, Maria Kirby, Rcbecca Rix, Jed Rubenfeld, Kenji Yoshino, Philipp Ziesche, and especially Reva Siegel for their invaluable help at various stages of this project. 1 am also indebted to Katherine Florey, Jean Galbraith, and the California Law Review staff for superb editorial assistance. 
D. "The Only Consistent Position": Consolidation of a Dual Constitutional Strategy, 1966-1970

1. Constitutional Roads Not Taken: Human Rights Amendments and the Price of Unity

2. "The ERA Need Not Compete with the Fourteenth Amendment": The Dual Strategy Ascendant 793

3. "New Tools for the Tools that Have Failed You": The Dual Strategy Triumphant. 796

II. Implementing the Dual Constitutional Strategy: The Dilemmas of Advocacy 801

A. "If Properly Interpreted": The Fourteenth Amendment in ERA Advocacy. 802

B. "New Language Is Required": The Rise and Fall of the Bayh Substitute 808

C. "We Have Taken a Baby Step": The Dual Strategy in the Supreme Court

D. "What Harm Redundance?" Advantages and Pitfalls of the Dual Strategy

III. Legal Feminism's Constitutional Legacy....................................... 823

A. The Paradoxes of Pragmatism ................................................ 824

B. The Dual Strategy's Legacies in Constitutional Sex Equality Jurisprudence 826

1. Vindication: United States v. Virginia ................................. 826

2. Constrained Constitutional Choices: Nguyen v. INS ........... 830

3. The Creation of Constitutional Culture: Nevada Department of Human Resources v. Hibbs

C. Current Constitutional Controversies and the Lessons of History 


\title{
Constitutional Choices: Legal Feminism and the Historical Dynamics of Change
}

\author{
Serena Mayeri
}

Using a historical case study, this Article seeks to uncover how advocates of change construct and confront constitutional choices. In the 1960s and early 1970s, activists concerned with women's legal status struggled to define and effectuate a platform of constitutional change. After decades of bitter division over the Equal Rights Amendment, they overcame longstanding racial, class, and ideological rifts to unite around a dual strategy-the simultaneous pursuit of a constitutional amendment and judicial reinterpretation of the Fourteenth Amendment. The Article explores the dual strategy's formulation, articulation, and execution, examining the costs and benefits of building and implementing this nascent feminist consensus. It concludes by considering the dual strategy's legacy in constitutional sex equality jurisprudence and briefly reflecting upon the stakes of the choices facing today's advocates of constitutional change.

\section{INTRODUCTION}

Twenty-first-century constitutional sex equality jurisprudence is replete with apparent contradictions. In I996, the Supreme Court resoundingly disapproved the exclusion of women from the Virginia Military Institute (VMI), announcing a muscular "skeptical scrutiny" for sex-based classifications that some heralded as the judicial enactment of an Equal Rights Amendment (ERA). ' But five years later, a majority of justices applied a much less robust version of intermediate scrutiny to uphold a sexdifferentiating citizenship law. ${ }^{2}$ In 2000, the Court struck down the Violence Against Women Act's civil rights remedy as an unconstitutional exercise of congressional power, ${ }^{3}$ then surprised observers three years later by sustaining the Family and Medical Leave Act (FMLA) as a valid legislative attempt to combat sex discrimination under Section five of the

1. United States v. Virginia, 518 U.S. 515, 531 (1996).

2. Nguyen v. 1NS, 533 U.S. 53 (2001).

3. United States v. Morrison, 529 U.S. 598 (2000). 
Fourteenth Amendment. ${ }^{4}$ Present-day political alignments and calculations play an important role in shaping doctrinal outcomes, but the roots of these decisions also lie in the constitutional choices of the past. This Article chronicles the creation of the feminist legal strategy that helped to shape our current constitutional landscape. ${ }^{5}$

In the 1960s, advocates concerned with women's legal rights-a group I will call "legal feminists"-were embroiled in a long-standing, passionate, and divisive dispute over whether their goal of equal justice under the law could best be achieved through an ERA or through judicial reinterpretation of the Fourteenth Amendment. This constitutional choice had profound affective and symbolic significance, implicating personal and political loyalties that transcended the provisions' text. For some, Fourteenth Amendment litigation was strongly associated with protectionism, concern for working-class women, and solidarity with racial minorities, while the ERA connoted formal equality, elitism, and even white supremacy. For others, the Fourteenth Amendment was a debilitating decoy designed to sap constitutional change of its egalitarian power. For a third group, increasingly, the choice between litigation and constitutional amendment pursuant to Article $\mathrm{V}^{6}$ was a pragmatic one. These pragmatists, led by African-American civil rights attorney and pioneering feminist Pauli Murray, asked which avenue of constitutional change would most expeditiously unite a diverse group of activists around a common legal strategy and would most likely succeed in the larger political universe. Thanks in no small measure to the leadership of Murray and her allies, and aided by the passage of Title VII of the Civil Rights Act of 1964, by the early 1970s legal feminists had overcome their differences and settled on a dual constitutional strategy: the simultaneous pursuit of constitutional change through formal amendment and judicial reinterpretation. The process by which they achieved this accord is recounted in Part I of this Article.

4. Nev. Dep't of Human Res. v. Hibbs, 538 U.S. 721 (2003).

5. As the Court claims a superior prerogative to define constitutional rights and powers, scholars have begun to excavate and emphasize the central role played by extrajudicial sources in the creation of constitutional meaning. See, e.g., Robert C. Post \& Reva B. Siegel, Equal Protection by Law: Federal Antidiscrimination Legislation After Morrison and Kimel, 110 Y ALE L.J. 441 (2000) [hereinafter Post \& Siegel, Equal Protection by Law]; Robert C. Post \& Reva B. Siegel, Legislative Constitutionalism and Section Five Power: Policentric Interpretation of the Family and Medical Leave Act, 112 YALE L.J. 1943 (2003) [hereinafter Post \& Siegel, Legislative Consitutionalism]; Reva B. Siegel, Text in Contest: Gender and the Constitution from a Social Movement Perspective, 150 U. PA. L. REv. 297 (2001); see also William N. Eskridge, Jr., Channeling: Identity-Based Social Movements and Public Law, 150 U. PA. L. Rev. 419 (2001) [hereinafter Eskridge, Jr., Channeling]; William N. Eskridge, Jr., Some Effects of Identity-Based Social Movements on Constitutional Law in the Twentieth Century, 100 Mich. L. Rev. 2062 (2002) [hereinafter Eskridge, Jr., Some Effects]; Edward L. Rubin, Passing Through the Door: Social Movement Literature and Legal Scholarship, 150 U. PA. L. REv. 1 (2001).

6. See U.S. ConST. art. V (describing procedure for proposing and ratifying amendments to the Constitution). 
Part I further explores how consensus proved to be a mixed blessing. On the positive side, feminist convergence around the dual approach finally ended the opportunistic alliances some ERA proponents had forged with racial segregationists. In its early stages, the dual strategy also led to a reinvigoration of the movement's ideals and goals. Activists who sought judicial reinterpretation of the Fourteenth Amendment put forth an expansive constitutional vision that embraced the interconnectedness of race and sex equality. Advocates of a constitutional amendment developed proposals for new versions of the ERA that linked the principle of sex nondiscrimination to reproductive freedom and racial justice. In the end, though, unity came at a price. Advocates' failure to obtain a favorable court decision under the Fourteenth Amendment on the issue of Southern jury service stymied an avenue of reform that linked women's rights with issues of race and class. The insistence of longtime ERA supporters upon retaining the ERA's original wording further constrained legal feminists' constitutional choices, dooming more capacious visions of equality. Indeed, studying the constitutional choices legal feminists faced during the 1960 s helps to explain the emergence of what critics of post-1970 jurisprudence ${ }^{7}$ have identified as a formalistic, exclusive, and impoverished notion of equality, one that severed feminism from other social justice causes and benefited the privileged classes at the expense of the poor and women of color. ${ }^{8}$

Part II demonstrates that implementing the dual strategy-the legal feminist project of the $1970 \mathrm{~s}$-also involved both advantages and pitfalls. On the one hand, legal feminists' unprecedented unity made the seventies an auspicious decade for surmounting the judicial obstinacy that had long rankled women's rights advocates. As Congress and the Court considered women's constitutional demands, legal feminists enthusiastically promoted the dual strategy, insisting that they were entitled to seek constitutional change through formal amendment and judicial reinterpretation simultaneously. The interaction of these processes had many salutary consequences for feminists, but the hazards of a dual approach soon became apparent. While some jurists believed that congressional passage of the ERA

7. Mary Becker's focus on the 1960s is exceptional. See Mary Becker, The Sixties Shift to Formal Equality and the Courts: An Argument for Pragmatism and Politics, 40 WM. \& MARY L. REv. 209 (1998).

8. For a sampling of such critiques, see Kathryn Abrams, The Constitution of Women, 48 ALA. L. Rev. 861 (1997); Kimberlé Crenshaw, Demarginalizing the Intersection of Race and Sex: A Black Feminist Critique of Antidiscrimination Doctrine, Feminist Theory, and Antiracist Politics, 1989 U. Ch1. Legal F. 139; Angela P. Harris, Race and Essentialism in Feminist Legal Theory, 42 Stan. L. Rev. 581 (1990); Christine A. Littleton, Equality and Feminist Legal Theory, 48 U. PiTT. L. REv. 1043 (1987); Catharine MacKinnon, Reflections on Sex Equality Under Law, 100 YALE L.J. 1281 (1991); Catharine MacKinnon, Unthinking ERA Thinking, 54 U. CHI. L. REv. 759 (1987) (book review). For a trenchant critique of the assimilationist tendencies in equal protection doctrine more generally, see Kenji Yoshino, Assimilationist Bias in Equal Protection: The Visibility Presumption and the Case of "Don't Ask, Don't Tell," 108 Y ALE L.J. 485 (1998). 
militated in favor of judicial reinterpretation of the Fourteenth Amendment, others felt that the Court was obliged to await the outcome of ERA ratification procedures. Just as ERA advocacy could limit feminists' litigation successes, progress in the courts made an ERA seem less necessary. ${ }^{9}$ The dual strategy, born of pragmatism, spawned its own practical conundrums.

Part III first considers the paradoxes of legal feminists' pragmatism, noting that while Pauli Murray's intersectional perspective was an important impetus for the dual strategy, her indefatigable attempts to place African-American women at the center of constitutional change were only partially successful. Further, the dual strategy itself was doomed to achieve only a partial triumph, encouraging the Supreme Court to adopt a heightened standard of review for sex-based classifications but also providing a rationale for stopping short of the strict scrutiny standard legal feminists sought.

The paradoxes of the dual strategy's legacy reverberate across our constitutional landscape to this day. Part III goes on to argue that the seemingly contradictory outcomes of recent constitutional sex equality cases reflect many of the strengths and limitations of legal feminism as it developed in the 1960s and I970s. While the strategy legaI feminists pursued was not outcome-determinative by any means, the constrained choices feminists made echo through contemporary constitutional discourse. ${ }^{10}$

The Article concludes with a brief consideration of current constitutionaI controversies. While the historical particularity and contingency of the lcgal feminist experience caution against generalization, differences as well as similarities across time and context shed light on the stakes of advocates' constitutional choices today. Not only do these choices shape the way courts and other decision makers ultimately conceptualize equality,

9. Jane J. MANSBridge, Why We Lost the ERA 48-59 (1986); Mary Frances Berry, Why ERA Failed: Politics, Women's Rights, and the Amending Process of the Constitution 99100 (1986).

10. For fascinating accounts of other constitutional roads not taken, see William E. Forbath, Caste, Class, and Equal Citizenship, 98 Mich. L. REv. 1 (1999) (describing a "social citizenship" tradition that grapples with class inequality and economic justice in a way that the jurisprudence of formal racial equality does not); Risa L. Goluboff, The Thirteenth Amendment and the Lost Origins of Civil Rights, 50 DUKE L.J. 1609 (2001) (tracing an alternative path to racial and economic justice through the Thirteenth Amendment explored by Department of Justice (DOJ) lawyers in the 1940s); James Gray Pope, The Thirteenth Amendment Versus the Commerce Clause: Labor and the Shaping of American Constitutional Law, 1921-1957, 102 CoLum. L. REv. 1 (2002) (detailing the labor movement's Thirteenth Amendment theory of economic justice and its demise at the hands of progressive lawyers); Reva B. Siegel, She the People: The Nineteenth Amendment, Sex Equality, Federalism, and the Family, 115 HARv. L. REV. 947 (2002) (describing the wide range of social changes women's suffragc advocates sought but did not achieve in the wake of the Nineteenth Amendment's ratification). 
but the act of choosing in turn constructs the social movements that mobilize for change. ${ }^{11}$

I

Building a Strategy for Constitutional Change: The ERA, the Fourteenth Amendment, and Constitutional Roads Not Taken

As the turbulent 1960s began, women seeking to transform their legal and constitutional status faced two equally formidable obstacles: judicial intransigence and internal dissension. "Despite the enlightened emancipation of women from the restrictions and protections of bygone years, and their entry into many parts of community life formerly considered to be reserved to men," wrote Justice John Marshall Harlan in the 1961 case Hoyt v. Florida, "woman is still regarded as the center of home and family life."'2 Such ambivalence about women's proper public and private roles permeated American law at the federal, state, and local levels. Even among women's advocates, long-standing antagonisms divided supporters of an ERA from those dedicated to preserving hard-won protective labor legislation for women. As the Warren Court increasingly embraced a revolution in African Americans' legal status, women's rights leaders disagreed, sometimes bitterly, over their cause's relationship to the civil rights movement. Meanwhile, the dominant constitutional discourse allowed little room for heightened scrutiny of sex-discriminatory laws, given women's inability to claim the "discrete and insular minority"13 status that rationalized judicial remediation of invidious legal distinctions under the Fourteenth Amendment.

This Part examines the choice between two principal modes of constitutional change that legal feminists faced during the 1960s. By relating the story of how feminists overcame deep divisions over the ERA, the first two sections show the extent to which internal social movement dynamics, ideological differences, and substantive, symbolic, and affective attributes

II. I use the term "social movement" to include individuals and organizations who functioned as policy insiders as well as outsiders. As John D. Skrentny has noted, while "[s]cholars almost always assume social movements are discrete entities that exist outside of government," in the late 1960s and early 1970s "formal members of social-movement organizations held positions of power" in government and "played crucial roles in formulating and pushing new rights." JOHN D. SKRENTNY, The Minority Rights Revolution 5 (2002).

12. 368 U.S. 57,62 (1961).

13. United States v. Carolene Prods. Co., 304 U.S. 144, 152 n.4 (1938) (suggesting that "prejudice against discrete and insular minorities may be a special condition, which tends seriously to curtail the operation of those political processes ordinarily to be relied upon to protect minorities, and which may call for a correspondingly more searching judicial inquiry."). For an argument that larger and more diffuse groups have a more difficult time than discrete and insular minorities prevailing in the political process, see Bruce A. Ackerman, Beyond Carolene Products, 98 HaRv. L. Rev. 7 I3 (1985). See also Kathleen M. Sullivan, Constitutionalizing Women's Equality, 90 CALIF. L. REv. 735, 742 (2002) (" $[\mathrm{L}]$ ike the Holy Roman Empire-which was neither holy, Roman, nor an empire--women are neither discrete, insular, nor a minority."). 
associated with the ERA and its alternatives shaped advocates' constitutional choices. The final sections describe constitutional roads not taken, exploring the costs and benefits involved in unification around a dual constitutional strategy that foreclosed more expansive modes of change.

\section{A. "We May Escape from Our Dilemma": Pauli Murray and the Resurrection of the Fourteenth Amendment, 1962-63}

Since the early 1920s, American feminism had been divided, often sharply, into two opposing camps. One, composed primarily of Alice Paul's National Woman's Party (NWP) and some professional women's groups, insisted that an ERA eliminating all legal distinctions between men and women was necessary to secure women's equal status in American society. ${ }^{14}$ Special laws for women, these equalitarians believed, served to "protect" them not from dangerous working conditions so much as from advancement in traditionally male-dominated occupations. The other faction, exemplified at various points by Florence Kelley, Eleanor Roosevelt, Mary Anderson, and Esther Peterson, fought hard for protective labor legislation-minimum wage, maximum hours, and weightlifting regulations-for women at a time when substantive due process doctrines precluded the enactment of similar laws for male laborers. ${ }^{15}$ The protectionists balked at any formal equality measure that might undermine those gains, which they believed were essential to the well-being of working women. Between 1923 and the late 1950s, the NWP's small but determined cadres persistently pressed the ERA in Congress, without much success. Allies of the protectionists were equally determined, often attaching riders and amendments to exempt protective labor laws from coverage and effectively negate the amendment's purpose. ${ }^{16}$

When the President's Commission on the Status of Women (PCSW) ${ }^{17}$ convened in late 1961, many participants were eager to develop an

14. For more on the NWP, see generally SUSAN D. BECKER, THE ORIGINS OF THE EQUal RightS amendment: American Feminism Between the Wars (1981); Nancy F. Cott, The Grounding of Modern Feminism (1987); Christine A. Lunardini, From Equal Suffrage to Equal Rights: Alice Paul and the National Woman's Party, 1910-1928 (1986); Lella J. Rupp \& Verta Taylor, Survival in the Doldrums: The American Women's Rights Movement, 1945 TO THE 1960s (1987); Nancy F. Cott, Feminist Politics in the 1920s: The National Woman's Party, 71 J. AM. Hist. 43 (1984).

15. For more on the debates over protective labor legislation, see VIVIEN $H_{A R T}$, Bound BY OUR Constitution: Women, Workers, and the Minimum Wage (1994); Joan G. Zimmerman, The Jurisprudence of Equality: The Women's Minimum Wage, the First Equal Rights Amendment, and Adkins v. Children's Hospital, 1905-1923, 78 J. AM. Hist. 188 (1991).

16. See, e.g., Cynthia Harrison, On Account of Sex: The Politics of Women's Issues, I 945-1968, at 30-38 (1988) (discussing Sen. Carl Hayden's amendment, which read: "The provisions in this article shall not be construed to impair any rights, benefits, or exemptions conferred by law upon persons of the female sex.").

17. Cynthia Harrison has provided the most comprehensive treatment of the PCSW's work. See id. 
alternative legal strategy that could circumvent the divisive debate over the ERA. In 1962, the PCSW's Committee on Civil and Political Rights (CCPR) asked Pauli Murray, an attorney and civil rights expert, to evaluate the strategies available to those concerned with women's legal position in American society. Murray, then a fifty-one-year-old doctoral student at Yale Law School, was a veteran of struggles for racial equality. After unsuccessfully challenging the color barrier at the University of North Carolina's graduate school in $1938,{ }^{18}$ Murray had attended Howard University Law School, where she helped lead World War II-era sit-ins in segregated Washington, D.C. restaurants and advocated a direct challenge to separate-but-equal educational institutions in a research paper later used by the Brown v. Board of Education ${ }^{19}$ litigation team. ${ }^{20}$ Murray was also no stranger to battles for sex equity. In 1944, about to graduate first in her law school class, she was denied on the basis of sex the Harvard Law School fellowship traditionally awarded to top Howard graduates. Deeply hurt by the cavalier attitudes of many of her male Howard colleagues toward her plight, ${ }^{21}$ Murray pledged to dedicate herself to vanquishing "Jane Crow" as well as "Jim Crow."22

Murray's PCSW memorandum recommended a renewed effort to litigate women's rights under the Fourteenth Amendment and transformed feminist constitutional horizons in a manner that still reverberates today. ${ }^{23}$ After conducting extensive legal research, Murray proposed a litigation strategy modeled on the civil rights movement's successful transformation of the Fourteenth Amendment's judicial meaning. ${ }^{24}$ She articulated a

18. For more on Murray's challenge to the University of North Carolina's exclusionary policy, see Pauli Murray, The autobiography of a Black Activist, Feminist, Lawyer, Priest and POET 108-12, 115-29 (1987); Glenda Elizabeth Gilmore, Admitting Pauli Murray, 14 J. WoMEN's Hist. 62 (2002). For an excellent introduction to Murray's significance as a historical figure, see Dialogue: Pauli Murray's Notable Connections, 14 J. Women's Hist. 54 (2002).

19. 347 U.S. 483 (1954).

20. Murray recounts in her autobiography that then-Howard law professor Spottswood Robinson bet her ten dollars in 1944 that Plessy would not be overruled for at least twenty-five years. Many years later, she collected on the bet, and Robinson surprised her by relating how he and his NAACP colleagues had relied on her law school work in composing their briefs for Brown. MURRAY, supra note 18 , at $221-22$

21. Id. at 240 ("The fact that Harvard's rejection was a source of mild amusement rather than outrage to many of my male colleagues who were ardent civil rights advocates made it all the more bitter to swallow."). For more on Murray's attempt to gain admission to Harvard Law School, see Rebels in LaW: Voices in History of Bl.ack Women Lawyers 79 (J. Clay Smith, Jr., ed., 1998) (reprinting Murray's letter to the Harvard Corporation).

22. Murray, supra note 18 , at 244

23. Pauli Murray, A Proposal To Reexamine the Applicability of the Fourteenth Amendment to State Laws and Practices Which Discriminate on the Basis of Sex Per Se 10 (Dec. 1, 1962) (PCSW Papers, Doc. 11-20, Box 8, Folder 62, on file with the Schlesinger Library, Radcliffe Institute, Harvard University) [hereinafter Murray, Proposal To Reexamine].

24. Id. at 8-9; PCSW, CCPR, Report of Meeting Held August 24, 1962, at 3 (Oct. 15, 1962) (PCSW Papers, Doc. A-3, Box 8, Folder 61, on file with the Schlesinger Library, Radcliffe Institute, Harvard University) [hereinafter Report of Meeting Held August 24, 1962] ("Miss Pauli 
standard of "heightened reasonableness" designed to enable courts to identify invidiously discriminatory laws that disadvantaged and demeaned women, while preserving the truly protective laws to which Esther Peterson and other labor activists were committed. Drawing heavily on an analogy between race and sex discrimination, ${ }^{25}$ Murray sought to emulate the success of organizations like the NAACP Legal Defense Fund in winning rights through organized litigation. ${ }^{26}$

Murray believed that the benefits of the Fourteenth Amendment strategy were manifold. First, the strategy provided a flexible, case-by-case approach that held the promise of eliminating pernicious discriminations against women, such as exclusion from jury service, without disrupting protections important to labor advocates. As such, this approach was strategically appealing because it provided a new agenda behind which feminists of various stripes could unite-an alternative to the bitter and counterproductive disputes that had stymied effective political action in the past. Finally, Murray realized that the Fourteenth Amendment strategy concretely linked the civil rights and women's rights movements at a time when the primary efforts toward constitutional change for women involved racist appeals to Southern segregationist legislators whom the NWP importuned for support in passing the ERA. ${ }^{27}$

Quickly perceiving the danger of continued polarization, Murray quite self-consciously viewed her role as a mediator between the protectionist and equalitarian factions. As she wrote to U.S. Representative Edith Green, also a PCSW member, "The controversy over the ERA seemed to force people who espoused the same goals into rigid positions and dissipated energies which might have gone toward a development of standards for the concept of equal status." ${ }^{28}$ Murray herself was not opposed to the substance of the ERA; rather, she believed that insufficient support among women's

Murray... pointed out that court action on the 14th Amendment had been more effective than legislative efforts in the struggle for Negro rights.").

25. For more on the origins and uses of race-sex analogies, see Serena Mayeri, Note, " $A$ Common Fate of Discrimination": Race-Gender Analogies in Legal and Historical Perspective, 110 Yale L.J. 1045 (2001); see also Alice Kessler-Harris, In Pursuit of EQuity: Women, Men, AND THE Quest for ECONomic Citizenship in 20Th-Century America 228-33, 241-89 (2001); SKRENTNY, supra note 11, at 86-87, 111-19, 130-4I. Murray's memorandum is also discussed in Harrison, supra note 16, at 126-30; Susan M. Hartmann, The Other Feminists: Activists in the Liberal Establishment 62-63 (I998); Linda K. Kerber, No Constitutional Right To Be Ladies 189-93 (1998); Kessler-Harris, supra, at 229-32; Judith Paterson, Be Somebody: A BIography of Marguerite Rawalt 138 (1986); Becker, supra note 7, at 222-31; Rosalind Rosenberg, Pauli Murray and the Killing of Jane Crow, in ForgotTen Heroes 279 (Susan Ware ed., 1998).

26. Murray, Proposal to Reexamine, supra note 23, at 21.

27. See infra Part I.B.1.

28. Letter from Pauli Murray to Rep. Edith Green (D-OR) (Jan. 24, 1963) (Pauli Murray Papers, MC 412, Box 49, Folder 878, on file with the Schlesinger Library, Radcliffe Institute, Harvard University). 
groups for a new amendment precluded its success but did not bar a constructive attempt at constitutional change through judicial reinterpretation of the Fourteenth Amendment. ${ }^{29}$ When pressed, she reassured laborites that a Fourteenth Amendment approach would shield protective labor legislation from challenge. ${ }^{30}$ In an internal memorandum to members of the CCPR, she articulated the strategy behind her proposed draft of the final committee report:

[I]t seeks to approve the underlying principle of the Equal Rights Amendment ... without taking any position on that Amendment or referring to it by name. If we could build up the Fourteenth Amendment in this way without sacrificing the principle of the ER Amendment, we may escape from our dilemma. ${ }^{31}$

Reaction to Murray's memorandum was mixed. At one end of the spectrum, some perceived Murray's proposal as too radical: Harvard Law School Dean Erwin Griswold, for instance, praised her "excellent memorandum," but confessed that he found himself "rather luke warm" about her equation of race and sex discrimination." "Somehow or other, it has always seemed to me that there are differences in sex, and that these differences may, in appropriate cases, be the basis of classification for legal purposes," he wrote..$^{33}$ The National Council of Jewish Women similarly feared that the logical conclusion of the race-sex analogy was the removal of all sex-based distinctions from the law. ${ }^{34}$ The AFL-CIO, while

29. Murray recalled later that her memo was "careful not to disclaim the ultimate need for an equal rights amendment. It had seemed to me that given the absence of broad public support for the ERA at the time, the Fourteenth Amendment approach was a practical intermediate step. If successful, it might achieve on a case-by-case basis the same objectives as ERA supporters envisioned, but if the courts failed to respond favorably, then the case for the ERA was unassailable." MURRAY, supra note 18, at 351-52. See also Letter from Skipper (Caroline Ware) to Pixie (Pauli Murray) (Oct. 12, 1962) (Pauli Murray Papers, MC 412, Box 49, Folder 878, on file with Schlesinger Library, Radcliffe Institute, Harvard University) (advising Murray to avoid taking a stand on the amendment since "[ $t]$ he moment you do... you invite opposition from a quarter which will support you if you keep strictly silent on the 'equal rights' issue").

30. See, e.g., Letter from Pauli Murray to Katherine P. Ellickson (Oct. 13, 1962) (Pauli Murray Papers, MC 412, Box 49, Folder 876, on file with the Schlesinger Library, Radcliffe Institute, Harvard University) ("First, let me say that my position on labor legislation protective in nature is that it should not be disturbed.").

31. Memorandum from Pauli Murray to Edith Green, Frank Sander, Harriet Pilpel, Marguerite Rawalt, Mary Eastwood, Katherine Ellickson, and Mrs. Hilton, Re: Fourteenth Amendment-Equal Rights Amendment Statement (Mar. 12, 1963) (Mary Eastwood Papers, 83-M257, Carton 1, Folder 59, on file with the Schlesinger Library, Radcliffe Institutc, Harvard University).

32. Letter from Erwin N. Griswold to Pauli Murray (Jan. 31, 1963) (Pauli Murray Papers, MC 412, Box 49, Folder 878, on file with the Schlesinger Library, Radcliffe Institute, Harvard University).

33. Id.

34. See Statement of Mrs. Samuel Brown, National Council of Jewish Women, before the CCPR of the PCSW 4 (Mar. 8, 1963) (Pauli Murray Papers, MC 412, Box 49, Folder 883, on file with the Schlesinger Library, Radeliffe Institute, Harvard University). "As a philosophical and sociaological [sic] concept it may have some validity," Brown said of the race-sex parallel, but she worried that "the 
preferring the Fourteenth Amendment litigation approach to the ERA, declined fully to endorse the Murray memo. The labor union feared "sweeping judicial pronouncements that employers might seize upon to turn against proteetive labor legislation" 35 and called for legislation that would address private discrimination in employment rather than curb public sex-differentiating practices. ${ }^{36}$

A range of individuals and groups supported the Fourteenth Amendment approach both because it offered a chance of substantive success and because it might undercut the ERA. The ACLU, a longtime opponent of the ERA, ${ }^{37}$ enthusiastically embraced the Murray proposal as a vindication of its stance. ${ }^{38}$ ACLU Equality Committee Chair and longtime women's rights advocate Dorothy Kenyon wrote to the PCSW: "Miss Murray's analysis heartens us in our belief that the equality clause of the XIV Amendment looks like the best constitutional instrument at hand for the reflection of the social changes involved in the changing status of women." 39 Paul Freund, a protégé of Louis Brandeis and professor at Harvard Law School who had testified against the ERA before Congress in the 1940s, also welcomed Murray's proposal, noting that it allowed "the questions involved ... to be approached on a particularistic and flexible basis." 40

Supporters of the Fourteenth Amendment approach occasionally pointed to the activist constitutional climate of the Warren Court era as a reason for optimism about judicial reinterpretation of existing provisions. Murray's proposal itself emphasized that courts often responded to shifts in community values and noted that the Fourteenth Amendment "had been invoked successfully in those instances where the shocking injustice of a situation cut through the subjectivities of the judges."41 Senator Carl

attempt to equate the two kinds of discrimination carries with it the implication that differential legal trcatment for women is not aeeeptable." Id.

35. Statement of the AFL-ClO on Methods of Removing Legal Discrimination Against Women, Submitted to CCPR of the PCSW 4-5 (Mar. 13, 1963) (PCSW Papers, B-26, Box 9, Folder 63, on file with the Schlesinger Library, Radcliffe Institute, Harvard University) [hereinafter Statement of the AFL-CIO].

36. Id. at 6 .

37. On the ACLU's opposition to the ERA prior to 1970, see HARTMANN, supra note 25, at 59, 73; see also infra Part I.D.3.

38. Indeed, as an alternative to the ERA, the ACLU had previously advocated a three-pronged strategy to fight invidious discrimination against women: litigation, legislation at the state and federal levels, and efforts to combat private discrimination. See, e.g., Memorandum from Pat Malin to ACLU Equality Committee, Re: Removing Discrimination Against Women (Nov. 17, 1959) (ACLU Records, Box 1 142, Folder 23, on file with the Mudd Manuscript Library, Princeton University).

39. Memorandum from Dorothy Kenyon 4 (Mar. 28, I963) (PCSW Papers, B-26, Box 9, Folder 63, on file with the Schlesinger Library, Radcliffe Institute, Harvard University).

40. Letter from Paul A. Freund to Esther Peterson (Mar. 11, 1963) (Mary Eastwood Papers, 83M257, Carton 1, Folder 58, on file with the Schlesinger Library, Radcliffe Institute, Harvard University).

41. Murray, Proposal to Reexamine, supra note 23, at 30. 
Hayden, a key congressional ally of the protectionist partisans, noted that "court decisions... have demonstrated the adaptability of constitutional standards to meet new problems and changing conditions."42 Skeptics evaluated the potential for judicial reinterpretation of the Fourteenth Amendment more pessimistically. Alice G. Andrews, a friend of Murray's, did not believe in asking the courts "to take up what is basically a legislative function" unless "there is an extreme case of discrimination raised by an individual and, as in the struggle for negro [sic] rights, it can be [attached to] a broad social problem in this country." ${ }^{43}$ In general, Andrews did not find cases of discrimination against women to be "necessarily that extreme." 44

For Murray and some of her colleagues on the CCPR, the Fourteenth Amendment approach was not an end run around the ERA's ultimate objective but an alternative means to a similar end. Mary Eastwood, a Department of Justice (DOJ) attorney who served as the committee's technical secretary, explained that the statement issued by the committee was "essentially a compromise" designed to "render an amendment unnecessary." 45 She emphasized that the agreed-upon language was not intended "to suggest that women's organization[s] and individuals who are seeking passage of the equal rights amendment should cease their efforts." 46 Indeed, several proposed versions of the committee statement strongly implied that an amendment might be appropriate if litigation proved unavailing. ${ }^{47}$

In addition to mediating the conflict between protectionists and ERA proponents, the Fourteenth Amendment strategy held the promise of establishing stronger ties between women's rights advocacy and the existing civil rights agenda, as well as building on the past successes of the civil rights movement. Most obviously, the race-sex analogy on which Murray based her argument connected these causes in a substantively meaningful way..$^{48}$ Furthermore, Murray's litigation strategy called for increased ties to civil rights and civil liberties groups such as the NAACP and the ACLU, as

42. Statement by Sen. Carl Hayden, Equality of Rights for Men and Women (Oct. 1963), microformed on National Woman's Party Papers 1913-1974 [hereinafter NWP Papers], Misc 959, Reel 108 (Microfilming Corp. of Am.).

43. Letter from Alice G. Andrews to Pauli Murray (Nov. 13, 1962) (Pauli Murray Papers, MC 412, Box 49, Folder 876, on file with the Schlesinger Library, Radcliffe Institute, Harvard University).

44. Id.

45. Letter from Mary Eastwood to Judge Florence K. Murray (1963) (Mary Eastwood Papers, 83-M257, Carton 1, Folder 58, on file with the Schlesinger Library, Radcliffe Institute, Harvard University).

46. Id.

47. See, e.g., Letter from Katherine P. Ellickson, PCSW Executive Secretary, CCPR, to Norbert Schlei, Assistant Attorney General, DOJ (Apr. 18, 1963) (Esther Peterson Papers, Box 44, Folder 891, on file with the Schlesinger Library, Radcliffe Institute, Harvard University) (proposed statements attached).

48. Mayeri, supra note 25 , at 1055-72 
well as the DOJ. ${ }^{49}$ Litigation appealed to Murray as a tactic because, as she pointed out, thus far "court action on the 14th Amendment" had been "more effective than legislative efforts in the struggle for Negro rights." Moreover, in the heyday of the Warren Court, whose pioneering reinterpretation of the Fourteenth Amendment in race cases had already assumed legendary proportions, the possibilities for achieving change through the courts seemed stronger than ever. Even the skeptical AFL-CIO opined that, if women's groups were to pursue a litigation-based strategy, "[t]he present composition of the Supreme Court itself would not appear to be an unfavorable factor."

Murray had managed to win over much of the anti-ERA women's rights contingent with her Fourteenth Amendment approach, but initially she made no headway in convincing amendment partisans. Marguerite Rawalt, former president of the Federal Bar Association and the National Federation of Business and Professional Women (BPW), and the only proERA member of the CCPR, fought indefatigably to preserve within the commission's final statement the possibility of seeking a new amendment at some future time. ${ }^{52}$ Meanwhile, NWP members were adamant that the Fourteenth Amendment litigation strategy was nothing more than a deliberate attempt to undermine the ERA by pursuing what was, purely and simply, a lost cause. That longtime ERA opponent and Women's Bureau official Esther Peterson had given the proposal her blessing was itself enough to prejudice the NWP against it. ${ }^{53}$ In its public statements, the NWP emphasized that the Fourteenth Amcndment path was "wishful thinking"-utterly hopeless, impractical, and counterproductive. ${ }^{54}$

Privately, at least one NWP member even suspected Murray of spearheading an NAACP conspiracy to hijack the women's rights movement. ${ }^{55}$ Murray's "preoccupation," Miriam Holden posited, "is with the Negro problem, and her primary purpose seems largely to be an attempt to hitch that wagon to our Equal Rights Amendment star." 56 Such a linkage, Holden worried, would jeopardize the political viability of an ERA and "spell

49. Murray, Proposal to Reexamine, supra note 23, at 37 ; see also Pauli Murray, Draft Memorandum 5 (Aug. 24, 1962) (PCSW Papers, B-26, Box 8, Folder 61, on file with the Schlesinger Library, Radcliffe Institute, Harvard University).

50. Report of Meeting Held August 24, 1962, supra note 24.

51. Statement of the AFL-CIO, supra note 35, at 5.

52. HARRISON, supra note 16, at 132-34; PATERSON, supra note 25, at 143.

53. See, e.g., Letter from Emma Guffey Miller, Chairman, NWP, to Jane Grant (Nov. 22, 1963), microformed on NWP Papers, Misc 959, Reel 108 (Microfilming Corp. of Am.) ("Esther Peterson loaded the commission against equality.").

54. See, e.g., Miriam Y. Holden, Argument in Favor of the Equal Rights Amendment, Made at the Request of the National Woman's Party (Mar. 23, 1963) (Pauli Murray Papers, MC 412, Box 49, Folder 883 , on file with the Schlesinger Library, Radcliffe Institute, Harvard University).

55. I use similar language to discuss Holden's perspective in Mayeri, supra note 25, at I062.

56. Letter from Miriam Holden to Anita Pollitzer (Feb. 16, I963), microformed on NWP Papers, Misc 959, Reel 108 (Microfilming Corp. of Am.). 
disaster for our hopes," since "[t]he Southern states are sure to look with disfavor on any Constitutional legislation that is linked with the Negro problem." 57 Remarkably, Holden suggested that the civil rights movement-which by 1963 had enjoyed success that the NWP could only dream of - was attempting to co-opt the ERA for its own purposes; she accused the NAACP of conspiring to "infiltrate" the women's movement and "make use of it as a springboard for their own propaganda." 58

In the year of the landmark March on Washington for civil rights, some in the NWP were marching to the beat of the segregationist drummer. ${ }^{59}$ For them, equal rights for women - and by extension, the ERAwould only be sullied by an association with Black civil rights. In this context, the Fourteenth Amendment approach, based as it was on an analogy between race and sex discrimination, stood not only for a reluctance to sacrifice protective labor laws at the altar of formal equality, but also for the embrace of civil rights victories won and sought by African Americans. Ironically, it would take the passage of Title VII's sex discrimination prohibition-introduced by a sworn enemy of civil rights-to begin to extricate the ERA and its equalitarian proponents from their entanglement with racial segregationists.

\section{B. Title VII's Sex Amendment and the Creation of a New Civil Rights Constituency, 1963-65}

The 1964 passage of the Civil Rights Act, complete with Title VII's prohibition of sex discrimination in employment, had three important and lasting effects upon legal feminists' constitutional horizons. ${ }^{60}$ First, despite its origins in an unholy alliance between feminists and segregationists, Title VII's sex amendment marked the beginning of the end of overt racebaiting as an instrument of women's rights advocacy. Second, by creating an expectation of government intervention in private discrimination but no concomitant will to enforce the sex provision, Title VII galvanized feminists to fight for a cause they could all agree upon. Third, though it would take several years for the Equal Employment Opportunity Commission (EEOC) to establish a firm stance on protective labor legislation, Title VIl eventually triggered the demise of sex-specific protectionism. With the primary source of anti-ERA sentiment removed, feminists could unite behind a dual Fourteenth Amendment-ERA strategy by the end of the decade. In sum, although Title VII produced few immediate results for victims of

57. Id.

58. Id.

59. See, e.g., Nina Horton Avery, Report to the Membership of the NWP on President Kennedy's Conference at the White House on July 9, 1963, with Group of Leaders of Women's Organizations, Concerning President's Proposed Civil Rights Act of 1963 (July 15, 1963), microformed on NWP Papers, Misc 959, Reel 108 (Microfilming Corp. of Am.).

60. This section foeuses primarily on the first two effects, though the third is equally important. 
sex discrimination in employment, its passage proved highly significant in consolidating legal feminism as a force to be reckoned with and altering the terms of advocates' constitutional choices.

\section{Protecting the "White Christian Woman of United States Origin"}

In a way, the introduction of the sex amendment to Title VII marked the culmination of an odd courtship between Southern segregationist politicians and NWP feminists. For years, one of the NWP's primary legislative strategies had been to entice Southern congressmembers to introduce and support amendments to civil rights bills establishing protections for (white) women. ${ }^{61}$ From the perspective of Southern segregationists, such proposals simultaneously allowed for the demonstration of chivalrous regard for white womanhood and the prospect of defeating civil rights bills with the proverbial "killer amendment." In this respect, the introduction of Title VII's sex amendment by an avowed segregationist was not the peculiar aberration of some depictions. ${ }^{62}$ In February I964, encouraged by NWP members who were, at best, ambivalent about civil rights for African Americans, ${ }^{63}$ Rep. Howard W. "Judge" Smith of Virginia proposed the addition of sex to the prohibited categories of discrimination and was greeted by the ribald and indulgent laughter of many colleagues. ${ }^{64}$

Rep. Emanuel Celler of New York, a primary sponsor of the Civil Rights Act and a longtime ERA opponent, immediately rose in opposition to Smith's proposed amendment. Celler listed a parade of horriblescompulsory military service, the decline of traditional family relationships, and the invalidation of rape laws and protective labor legislation-that he feared would follow from the adoption of legal sex equality. ${ }^{65}$ Moreover, Celler contended, even if women did experience some discrimination in

61. Rupp and Taylor attribute the NWP's alliances with segregationists to the racial insensitivity of many of its members, to the NWP's perception that white women's interests were antagonistic to those of African Americans, and to the NWP's generally opportunistic approach to ERA advocacy. RuPP \& TAYLOR, supra note 14, at 160-62.

62. For more on subsequent misrepresentations of the Title VII debate, see Jo Freeman, How "Sex" Got into Title VII: Persistent Opportunism as a Maker of Public Policy, 9 LAW \& INEQ. 163 (1991); see also Carl M. Brauer, Women Activists, Southern Conservatives, and the Prohibition of Sex Discrimination in Title VII of the 1964 Civil Rights Act, 49 J. S. HisT. 37 (1983).

63. See, e.g., Letter from B. Franklin, NWP, to Rep. Howard W. "Judge" Smith (D-VA) (Dec. 10, 1963), microformed on NWP Papers, Misc 959, Reel 108 (Microfilming Corp. of Am.).

Last evening my house guest ... and 1 were discussing the terrors inherent in the Civil Rights Act.... This morning we decided to telephone your office, and present a thought which may help change the Bill .... . Our idea is to add the word 'sex' .... This single word 'sex' would divert some of the high pressure which is being used to force this Bill through without proper attention to all of the effects of it. If any Bill is passed on the subject of Civil Rights, a great agitation is going to take place among the white women of America unless the word 'sex' is included.

Id.

64. 110 CONG. REC. 2577 (1964) (statement of Rep. Smith).

65. Id. (statement of Rep. Celler). 
employment, their progress toward equality was rapid compared to that of Negroes. ${ }^{66}$ Celler could comfortably oppose the sex amendment based both on his firm commitment to ending racial discrimination and on his stolid opposition to formal legal equality for women.

Rep. Martha Griffiths of Michigan, a longtime advocate of women's rights, issued a lengthy rebuttal in which she appealed to her colleagues not to leave white women unprotected from employment discrimination. "I rise in support of the amendment," announced Griffiths, "because I feel as a white woman when this bill has passed ... that white women will be last at the hiring gate." ${ }^{67}$ Despite her recognition at other points in the debate that Black women, too, were at risk without a sex amendment, Griffiths made a politic appeal to the prejudices of Southern congressmen. She posed several hypotheticals in an attempt to force Celler to admit that Title VII, without a sex amendment, would cover Black women but not white women. "[Y]ou are going to try to take colored men and colored women and give them equal employment rights, and down at the bottom of the list is going to be a white woman with no rights at all," she complained. ${ }^{68}$ Eager to undermine the race discrimination provisions of Title VII, Southern legislators chimed in to support Griffiths. One legislator warned that without the amendment, "the white women of this country would be drastically discriminated against in favor of a Negro woman."69 Much of the legislators' rhetoric echoed a 1963 NWP resolution, which had warned that "the Civil Rights Bill would not even give protection against discrimination because of 'race, color, religion or national origins,' to a White Woman, a Woman of the Christian Religion, or a Woman of United States Origin."70

Fearful that the alliance between feminists and Southerners would derail the entire civil rights bill, Rep. Edith Green, author of the Equal Pay Act, PCSW member, and longtime supporter of women's progress, professed her opposition to the amendment. Sardonically praising her Southern colleagues for their belated conversion to the women's rights cause, she acknowledged that discrimination against women in employment was an important and serious problem. But at the risk of being labeled an "uncle Tom" or "aunt Jane," as she put it, Green declared, "I do not believe this is the time or place for this amendment.... For every

66. Id. at 2578 .

67. Id. (statement of Rep. Griffiths).

68. Id. at 2579. Griffiths continued: "[W]hen the colored woman shows up and she is qualified, she is going to have an open entrée into any particular field....[W]hite men have done this before ... [Y] our greatgrandfathers [sic] were willing as prisoners of their own prejudice to permit exslaves to vote, but not their own white wives." Id. at 2579-80.

69. Id. at 2583 (statement of Rep. Andrews); see also id. at 2583 (statement of Rep. Rivers).

70. NWP Resolution (adopted Dec. 16, 1963), microformed on NWP Papers, Misc 959, Reel 108 (Microfilming Corp. of Am.) (emphasis in original), quoted in Brauer, supra note 62, at 43. 
discrimination that has been made against a woman in this country there has been 10 times as much discrimination against the Negro of this country." $" 71$ Understandably afraid to gamble on what was clearly intended by segregationists to be a killer amendment, Green could not join her female colleagues in their unanimous support of the sex provision. ${ }^{72}$

By contrast, Southern segregationist solicitude for the "White, Christian Woman of United States Origin" reflected the sentiments of many in the NWP, who had declared publicly that the Civil Rights Act sans sex amendment would subject such women to increasingly onerous discrimination. ${ }^{73}$ Furthermore, in correspondence with Southern legislators, some NWP officials had not only pleaded for the inclusion of white women in the civil rights bill, but had expressed their opposition to and even disgust at the prospect of civil rights for African Americans. A month before Judge Smith's introduction of the sex amendment, Nina Horton Avery, chair of the Virginia Committee of the NWP, sent a letter to her congressman declaring that the civil rights bill "in addition to extending the authority of the Executive Branch of our Government into preactically [sic] every facet of our lives ... regulate[s] white women of Christian relition [sic] to oblivion from every angle." ${ }^{\prime 7}$ She acknowledged the inevitability of civil rights legislation in some form, but expressed her gratitude to "the Members of Congress ... who will use their brains and energies to prevent a mongrel race in the United States and who will fight for the rights of white citizens in order that discriminations against them may be stopped."

Many NWP documents that did not express outright opposition to the civil rights bill nevertheless emphasized the particular dangers it posed to the employment aspirations of white native-born Christian women. An official NWP statement posited that, without the sex amendment, the civil rights bill would give "women of religious and racial minorities ... special government protection denied to ... the American-born white Protestant woman." 76 Even Emma Guffey Miller, a member of the Democratic National Committee and the NWP's national chair, argued for the sex

71. 110 CONG. REC. 2581 (1964) (statement of Rep. Green). Green continued: "As much as 1 hope the day will come when discrimination will be ended against women . . [this amendment] may later . . be used to help destroy this section of the bill by some of the very people who today support it." Id.

72. In Mayeri, supra note 25, at 1064-65, I use language similar to that of the prior three paragraphs above in discussing the responses of Celler, Griffith, and Green to Smith's proposed amendment

73. NWP Resolution, supra note 70.

74. Letter from Nina Horton Avery to Rep. J. Vaughan Gary (D-VA) (Jan. 8, 1964), microformed on NWP Papers, Misc 959, Reel 108 (Microfilming Corp. of Am.).

75. Id.

76. NWP, The Importance and Necessity of the Provisions in Title VIl of the Civil Rights Bill which Prevents Discrimination in Employment Against Women Workers (Mar. 6, 1964), microformed on NWP Papers, Misc 959, Reel 108 (Microfilming Corp. of Am.). 
amendment's urgency in terms of protecting white native-born Christian women from racial and religious discrimination. ${ }^{7}$

Significantly, the NWP's ERA advocacy was also bound up in this antagonistic view of the Civil Rights Act. Some NWP members hoped that an ERA would ensure that any legislation creating rights for racial and religious minority groups extended these rights to white Christian women. In early 1964, then, many NWP members saw the ERA as a corrective, rather than a complement, to the Civil Rights Act. Ultimately, passage of the sex amendment would alleviate those racialist concerns and pave the way for a more cooperative relationship between legal feminists and the civil rights movement.

\section{2. "Today It Is the Negro Women Who Will Win for All of Us Equal Rights": Title VII's Partial Triumph and the Retreat from Feminist Racialism}

NWP members were by no means unanimous in their ambivalence about civil rights legislation for African Americans. Some viewed the civil rights bill and the Black movement generally as a valuable source of momentum that women's rights advocates should capitalize on rather than struggle against. ${ }^{78}$ Alma Lutz, a historian of the women's suffrage movement, NWP member, and secretary of the Massachusetts Committee for the ERA, wrote to her colleagues in early 1964, "While the country is thinking in terms of complete citizenship for the Negro, it is important that there be no further delay in extending full citizenship to women through the adoption of the Equal Rights Amendment."79 NWP member Meta Heller was more explicit in her support for Black civil rights, writing to Emma Guffey Miller that while she "would be happy to serve" on the NWP committee forming to safeguard women's interests in the Senate debate over the Civil Rights Act, she felt that the bill was "terribly important." declared her belief that "today it is the negro [sic] women who will win for all of us equal rights. I only wish all women's organizations would get behind the civil rights movement, forgetting their prejudices for their own advancement." $" 81$

77. See, e.g., Letter from Emma Guffey Miller to Rep. Martha Griffiths (D-MI) (Jan. 20, I964), microformed on NWP Papers, Misc 959, Reel 108 (Microfilming Corp. of Am.).

78. Even some feminists who initially expressed ambivalence about the struggle for racial justice appreciated the genius of the civil rights movement and harangued their white female cohort for their lack of similar militancy. Margucrite Rawalt, for instance, wrote to a fellow lawyer in 1956 that "[i]f women had the sand that some of our minority ... groups have ... we would have [the ERA] enacted in short timc." PATERSON, supra note 25, at 115.

79. Letter from Alma Lutz to Colleagues (Jan. 21, 1964), microformed on NWP Papers, Misc 959, Reel I08 (Microfilming Corp. of Am.).

80. Letter from Mcta Heller to Emma Guffey Miller (Feb. 26, 1964), microformed on NWP Papers, Misc 959, Reel 108 (Microfilming Corp. of Am.).

81. Id. 
Pauli Murray cherished the same wish. The prevailing portrayal of the sex amendment as a favor to white women and a blow to Black civil rights impelled Murray to reframe the provision as centrally concerned with the rights of African-American women. ${ }^{82}$ As she wrote to Representative Griffiths in April 1964, "Having somewhat more than a speaking acquaintance with both Jim Crow and Jane Crow, it seems to be my lot to make the connection." ${ }^{83}$ When the sex amendment was in danger of failing in the Senate, Murray wrote a memorandum that was circulated among Senators and eventually reviewed by the White House, arguing that including sex as a prohibited basis for discrimination was the only way to extend the benefits of Title VII to the group that most needed them: Black women. She discredited Griffiths's suggestion that white women would be "last at the hiring gate" without a sex amendment:

What is more likely to happen ... [is that] in accordance with the prevailing patterns of employment both Negro and white women will share a common fate of discrimination, since it is exceedingly difficult for a Negro woman to determine whether or not she is being discriminated against because of race or sex. ${ }^{84}$

In fact, Murray urged, "A strong argument can be made for the proposition that Title VII without the 'sex' amendment would benefit Negro males primarily and thus offer genuine equality of opportunity to only half of the potential Negro work force." $\$ 85$

Although the passage of the Civil Rights Act of 1964 did not banish all racialist arguments from the NWP's rhetorical arsenal, ${ }^{86}$ the inclusion of sex discrimination alongside race discrimination in Title VII ironically prompted a shift away from the segregationist alliance that had shaped the Party's political sympathies before 1964-and that had helped to pass the sex amendment itself. Now that the NWP had won protection against sex discrimination, at least nominally, it was invested in the survival of the

82. For other discussions of Murray's role in the Title VIl debate, see HARRISON, supra note 16, at 180-81; KeSSLER-HARRIS, supra note 25, at 245-46; MURRAY, supra note 18, at 354-58; Becker, supra note 7, at 233-35; Mayeri, supra note 25, at 1063-67.

83. Letter from Pauli Murray to Rep. Martha Griffiths (D-M1) (Apr. 24, 1964) (Mary Eastwood Papers, 83-M257, Carton 1, Folder 7, on file with the Schlesinger Library, Radcliffe Institute, Harvard University).

84. Pauli Murray, Memorandum in Support of Retaining the Amendment to H.R. 7I52, Title VIl (Equal Employment Opportunity) to Prohibit Discrimination in Employment Because of Sex 20 (Apr. 14, 1964) (Pauli Murray Papers, MC 4I2, Box 85, Folder 1485, on file with the Schlesinger Library, Radcliffe Institute, Harvard University).

85. Id. at 20-21.

86. See, e.g., Letter from Laura Roberts to Sen. Sam Ervin and Sen. Everett Jordan (Sept. 15, I965), microformed on NWP Papers, Misc 959, Reel 109 (Microfilming Corp. of Am.) ("I see that all branches of the Federal Government ... are giving preferential treatment to the Negro over our own daughters, especially in the fields of employment and education. It is unthinkable that we should stand idly by while such injustice is taking place with ever increasing frequency."). 
civil rights statute and in feminist mobilization behind enforcement of the sex discrimination prohibition the Party had worked so hard to win.

Though the NWP would never deviate from its devotion to achieving an ERA at all costs, Party documents reflect a perceptible shift in 1964 and after in attitudes toward the Black civil rights movement and its relationship to feminism. To be sure, the new attitude was perhaps no less opportunistic than the old ${ }^{87}$ Nevertheless, Title VII helped to bring about a significant retreat from the explicitly racialist feminism the NWP had previously sponsored. The NWP's official tone first began to reflect the Alma Lutzes and Meta Hellers of the group during the Senate debate over Title VII, as it became clear that the viability of the sex discrimination provision depended directly upon the survival of the civil rights bill. In an August 1964 statement arguing for the retention of the sex amendment, the NWP took a somewhat more positive stance on African-American civil rights. While retaining language about white women's particular disadvantages, the statement also contained a section arguing that "Negro women suffer more discrimination than Negro men." 88 During an attempt to repeal Title VII in I965, Alma Lutz reminded her colleagues that "Title VII . . is particularly important to Negro women who, according to Government reports, suffer more from job discrimination than Negro men." 89

The danger of repeal passed fairly quickly, but the EEOC's enforcement priorities proved a more enduring threat to Title VII's impact on sex discrimination in employment. The EEOC's stated policy of giving lesser priority to sex discrimination claims than to race discrimination complaints soon alerted feminists to the need for political mobilization. ${ }^{90}$ Though the NWP and the protectionists disagreed about Title VII's impact on protective labor legislation, they could unite to press for procedures that would ensure the vindication of women's right to be free from discriminatory hiring, wage, promotion, and firing practices.

87. An unsigned, handwritten letter partially reproduced in the NWP collection recounts the group's changing disposition with respect to Title VII:

Before the $C R$ bill was passed the National W.P. made a study of its demands and reached the conclusion that the reports required and the liability of suits at law, would impose so large a demand on people... [that] the N.W. Party was active in working against the passage of the Civil Rights bill. However, when it became evident that the bill would pass, the N.W.P. worked devotedly to get coverage for the white, Christian, American born woman-the same protection as the colored woman, non Christian, foreign born woman was to enjoy.

Unsigned letter to "Gentlemen" 1-2 (Feb. 1965), microformed on NWP Papers, Misc 959, Reel 109 (Microfilming Corp. of Am.).

88. NWP Research Committee, Civil Rights for Women 6 (Aug. 1964), microformed on NWP Papers, Misc 959, Reel 109 (Microfilming Corp. of Am.).

89. Letter from Alma Lutz to Colleagues (Sept. 25, 1965), microformed on NWP Papers, Misc 959, Reel 109 (Microfilming Corp. of Am.).

90. For more on the EEOC's failure to enforce the sex discrimination provision of Title VIl, see Jo Freeman, The Politics of Women's liberation 76-79 (1975); Hugh Davis Graham, The Civil Rights Era: Origins and Development of National Policy, i 960-1972, at 205-32 (1990); HARRISON, supra note 16, at 192-206; KESSLER-HARRIS, supra note 25, at 246-47. 
Title VII also provided an unprecedented link between struggles for racial justice and sex equality. A crucial document articulating the importance of eradicating sex discrimination in employment and other fields was the seminal 1965 article "Jane Crow and the Law: Sex Discrimination and Title VII of the Civil Rights Act of I964," of collaborative effort between Pauli Murray and DOJ attorney Mary Eastwood, who had served together on the PCSW's CCPR. "Jane Crow and the Law," as its title suggested, argued for a strong moral and legal commitment to the elimination of sex discrimination based upon an analogy to race. Echoing Murray's earlier emphasis on the particular needs of Black women, the article brought together arguments against sex discrimination in private employment, to be combated under Title VII, and in public laws and practices, to be attacked through litigation under the Fourteenth Amendment. The race-sex analogy provided a framework justifying both endeavors and connecting them analytically, symbolically, and strategically. ${ }^{92}$

Murray pursued this analogy in a much-publicized speech to the National Council of Women in October 1965, in which she excoriated the EEOC's failure to enforce Title VII's anti-sex-discrimination provision and urged women to take concerted action on their own behalf. Murray told her audience that Title VII could prove as significant as the Nineteenth Amendment in advancing women's legal status, "[b]ut there is reason to believe that it will not be adequately enforced unless the political power of women is brought to bear. "93 The declaration that captured reporters' attention came at the end of her speech, when Murray said: "It should not be necessary to have another March on Washington in order that there be equal job opportunities for all. But if this necessity should arise, I hope women will not flinch from the thought." 94

Not surprisingly, the NWP was torn over how to react to Murray's reframing of the legislative and constitutional issues facing feminists. Less than three years earlier, Murray's use of rhetoric clearly referencing Black civil rights had provoked Miriam Holden to warn her NWP colleagues of

91. Pauli Murray \& Mary O. Eastwood, Jane Crow and the Law: Sex Discrimination and Title VII, 34 Geo. WASH. L. Rev. 232 (1965). Hugh Davis Graham calls this article the "intellectual benchmark" of the "internal women's dialectic" on equality. GraHAM, supra note 90, at 222.

92. Mayeri, supra note 25, at 1070-72.

93. Pauli Murray, Remarks at the Women and Title VII Conference, National Council of Women of the United States (Oct. 12, 1965) (Mary Eastwood Papers, 83-M257, Carton 1, Folder 34, on file with the Schlesinger Library, Radcliffe Institute, Harvard University) [hereinafter Murray, Remarks at the Women and Title VII Conference]; see also Letter from Pauli Murray to Marguerite Rawalt 1 (July 21,1965 ) (Mary Eastwood Papers, 83-M257, Box 5, Folder 56, on file with the Schlesinger Library, Radcliffe Institute, Harvard University) (worrying that "[w]omen's groups are divided and disorganized, and not fully aware of the implications of the sex provision to make a forward thrust on their own behalf."); Edith Evans Asbury, Protest Proposed on Women's Jobs, N.Y. TIMEs, Oct. I3, 1965 , at 32 .

94. Murray, Remarks at the Women and Title VII Conference, supra note 93. 
nefarious NAACP plots to co-opt the women's rights movement. But intervening events had utterly transformed Holden's opinion of Murray. ${ }^{95}$ She wrote to Alice Paul that the newspapers "did not fairly reflect the intention of [Murray's] speech, which was, I thought, an excellent one." 96 After quoting Murray's statement, Holden hastened to add: "I feel personally that it was extremely important and helpful to our cause that Dr. Murray took this objective and courageous position."97 Other accounts were somewhat less enthusiastic, however, lamenting Murray's failure to publicly embrace the ERA. Another NWP attendee, Dorothy Rogers, wrote Paul that "[w]hat Pauli Murray said was highly commendable, but she simply dodged the question of the Equal Rights for the Sexes Bill."98 Murray's civil rights orientation was no longer anathema to NWP members now that her dedication to the enforcement of Title VII's sex discrimination prohibition dovetailed with the group's own agenda. Nevertheless, they could not quite forgive her continued commitment to advancing the Fourteenth Amendment as a viable constitutional home for feminists' aspirations.

As the NWP's evolving attitude toward Murray illustrates, the passage of Title VII marked a turning point in feminist constitutional change advocacy. White supremacy no longer seemed complementary to-or even fully compatible with-feminist aspirations, now that the fortunes of antiracism and anti-sexism would, to some degree, rise and fall together. No longer were those who favored the Fourteenth Amendment approach and alliance with the civil rights movement condemned out of hand by ERA proponents as out-of-touch protectionists or race-obsessed conspirators. And, as Title VII's logic advanced the norm of equality at the expense of protection, the ERA slowly began to seem a less ominous threat to those who cherished the protective laws women's advocates had worked so hard to achieve.

\section{C. "We Differ Not So Much in Our Objectives as in Our Strategy": The Promise of the Fourteenth Amendment and the Articulation of the Dual Strategy, 1965-66}

By 1965, the NWP, the protectionists, and everyone in between could agree that pressuring the EEOC to devote resources to combating sex

95. Rawalt, too, had warmed up to Murray's approach. PATERSon, supra note 25, at 155 (noting that Rawalt's "reservations about Pauli Murray's approach to women's rights had disappeared.").

96. Letter from Miriam C. Holden to Alice Paul 1 (Oct. 16, 1965), microformed on NWP Papers, Misc 959, Reel 109 (Microfilming Corp. of Am.).

97. Id. at 2.

98. Letter from Dorothy Rogers to Alice Paul (Dec. 2, 1965), microformed on NWP Papers, Misc 959, Reel 109 (Microfilming Corp. of Am.). 
discrimination was an important objective for all feminists. ${ }^{99}$ NWP members had retreated far enough from their antagonism toward Black civil rights to fight segregationists on the attempted repeal of Title VII, and at least partially to endorse Murray's prescription for feminist mobilization. The NWP's actions had also begun to reflect a growing conviction that its interests might be best served by building upon, rather than undermining, the Black civil rights cause.

The jury exclusion issue presented just such an opportunity. In I965, Gardenia White and several other African-American women and men challenged their exclusion from the Lowndes County jury that had acquitted the men accused of killing civil rights activists Viola Liuzzo and Jonathan Daniels. In Alabama, as in Mississippi and South Carolina, the law excluded women of all races from jury service, while Black men were kept off juries through de facto custom. ${ }^{100}$ In White $v$. Crook, ${ }^{101}$ the ACLU and the DOJ joined forces to challenge both forms of jury exclusion, with attorneys Dorothy Kenyon and Pauli Murray drafting the portions of the plaintiffs' brief addressing the sex discrimination question. Feminists invested a great deal of hope in the White case. For adherents of the Fourteenth Amendment strategy, the jury exclusion issue held the promise of an ultimate Supreme Court pronouncement on the applicability of the Equal Protection Clause to sex discrimination.

The opportunity was tantalizing - a case that starkly and compellingly linked the civil rights and women's rights struggles, complete with what Fred Graham of the New York Times called the "all-purpose plaintiffNegro women." 102 The Supreme Court had been unconvinced of the sexdiscriminatory nature of differential jury service provisions for women and men in I961, when Justice Harlan had proclaimed women "the center of home and family life,"103 but what better case to convince them that such discrimination was a rights violation than a resonant instance of racial injustice? Such a precedent could forever connect the rights of white women and African Americans in the annals of constitutional jurisprudence, vindicating Murray's greatest hopes.

99. As Hugh Davis Graham recounts, Esther Pcterson was disturbed enough about the announced EEOC policy giving sex discrimination complaints short shrift to write a protest letter to the New York Times. Graham, supra note 90 , at 222.

100. African Americans were excluded, de facto, from jury service in many other Southern states as well. Alabama, Mississippi, and South Carolina were the only remaining states that, in the mid1960 s, still completely excluded women of all races from jury service, but many othcr statcs differentiated between men and women with respect to jury service. Some, for instance, automatically excluded womcn from jury rolls unless they specifically requested inclusion, with the practical effect that many juries through the United States were all male. The most comprehensive discussion of the jury exclusion issue appears in KERBER, supra note 25, at 124-220; see also HARTMANN, supra note 25, at 63-66 (discussing White v. Crook).

101. 251 F. Supp. 401 (M.D. Ala. 1966) (per curiam).

102. Fred P. Graham, Rights Case Yields Dividend for Women, N.Y. TimEs, Feb. 13, 1966, at 8E.

103. Hoyt v. Florida, 368 U.S. 57, 62 (1961). 
The window of opportunity would quickly slip away, however. The election of Richard Nixon in 1968 signaled to many the imminent demise of a judicial liberalism that celebrated the reinterpretation of constitutional provisions to encompass new rights and freedoms. While the lower court ruling in White kept alive hopes of success under the Fourteenth Amendment, pragmatic feminist strategists were one step closer to publicly expressing their conviction that an ERA might indeed be necessary.

\section{Feminists' Great White Hope}

In February 1966, a three-judge panel ${ }^{104}$ sitting in the Middle District of Alabama issued a ruling that thrilled feminists. ${ }^{105}$ In language reverberant with Warren Court-era expansiveness, the court declared that original intent was no bar to an interpretation of the Fourteenth Amendment that embraced principles of sex equality:

The Constitution of the United States must be read as embodying general principles meant to govern society and the institutions of government as they evolve through time. It is therefore this Court's function to apply the Constitution as a living document to the legal cases and controversies of contemporary society. When such an application to the facts in this case is made, the conclusion is inescapable that the complete exclusion of women from jury service in Alabama is arbitrary. ${ }^{106}$

A euphoric Mary Eastwood wrote to ACLU attorney Charles Morgan that the court's opinion was "far better than I had dared hope for. It's the most important thing to happen to women since the Nineteenth Amendment. (At least)."107 The ACLU leadership was delighted that its long-standing litigation-centered strategy was finally bearing fruit. ${ }^{108}$ The ACLU's Dorothy Kenyon, who unsuccessfully had urged the Supreme Court to eliminate sex discrimination in jury service in Hoyt $v$. Florida, ${ }^{109}$ and who had helped to argue White $v$. Crook in Alabama, wrote effusively: "Other victories will follow. But this one turned the key in the

104. As Linda Kerber notes, the three-judge panel that heard White v. Crook "was composed of men who had for more than a decade played a heroic part in ending [racial] segregation"-Richard T. Rives and Frank M. Johnson were particularly notable in this regard. KERBER, supra note 25, at 198.

105. See, e.g., MURRAY, supra note 18, at 364 ("We could hardly contain our joy on February 7 , 1966 , when the federal court ruled unanimously in favor of the plaintiffs with respect to both racial and sexual bias.").

106. White, 251 F. Supp. at 408.

107. Letter from Mary Eastwood to Charles Morgan, Director, Southem Regional Office, ACLU (Feb. 1966) (Mary Eastwood Papers, 83-M257, Carton 1, Folder 28, on file with the Schlesinger Library, Radcliffe Institute, Harvard University).

108. Press Releasc, ACLU, ACLU Wins Case on Exclusion of Negroes and Women from Juries in Alabama 2 (Feb. 28, 1966), microformed on NWP Papers, Misc 959, Recl 110 (Microfilming Corp. of Am.) ("The federal court deeision was a triumph for the ACLU's long held position that the Fourteenth Amendment's 'equal protection of the laws' applies to women.").

109. 368 U.S. 57 (1961). 
lock. Like the Civil Rights Boys when the Brown decision was handed down in 1954, "I could cry." 110 Protectionist standard-bearer Esther Peterson and Citizens' Advisory Council on the Status of Women (CACSW) Chair Margaret Hickey told the Washington Post that the decision made an ERA unnecessary. ${ }^{111}$

It soon became clear that the state of Alabama would not appeal the White ruling, depriving the jury exclusion issue of immediate consideration by the Supreme Court. ${ }^{12}$ However, all was not lost, since two other jury exclusion cases were pending in Mississippi state ${ }^{113}$ and federal court. Alvin Bronstein of the ACLU wrote to Catherine East in November 1966 that Willis $v$. Carson, a federal case challenging the exclusion of African Americans and white women from juries, would likely be decided in favor of the state of Mississippi. ${ }^{114}$ Noting that this would produce a conflict between two three-judge district courts, Bronstein predicted that the Supreme Court would soon rule on the sex discrimination issue.

Meanwhile, feminists were eager to capitalize on the White ruling in any way they could. Peterson called a meeting with Labor and DOJ lawyers to discuss the possible wider legal ramifications of the decision, and wrote to her boss that she and her colleagues were considering "how we might secure maximum publicity from the decision."115 A few weeks after the ruling, Peterson also convened a meeting of women government officials and leaders of women's organizations to discuss how to proceed. The gathering included Hickey and East of the women's status commissions, Eastwood of the DOJ, Mary Hilton of the Women's Bureau, and heads of groups including the NWP, BPW, the National Association of Women Lawyers (NAWL), and the American Association of University Women (AAUW). Also present were Marguerite Rawalt, the sole ERA proponent on the PCSW, and Dorothy Kenyon of the ACLU, who represented the

110. Letter from Dorothy Kenyon to Caroline Ware (Mar. 23, 1966) (Dorothy Kenyon Papers, Box 17, Folder 17, on file with the Sophia Smith Collection, Smith College).

111. Elizabeth Shelton, Verdict Stresses Women's Rights, WASH. Post, Feb. 19, 1966, at B7.

112. MURRAY, supra note 18 , at 364 .

113. After White was not appealed to the Supreme Court, the ACLU and its allies fixed their hopes on other cases, including one in the Mississippi Supremc Court. Letter from Melvin L. Wulf, ACLU Legal Director, to W.P. Mitchell (lawyer for plaintiff in jury exclusion case Mississippi v. Hall, 187 So. 2d 861 (Miss. 1966)) (Oct. 13, 1966) (ACLU Records, Box 1144, Folder 4, on file with the Mudd Manuscript Library, Princeton University) ("l would think that the prospects for the [U.S.] Supreme Court granting the appeal are excellent.").

114. Letter from Alvin J. Bronstein, Lawyers Constitutional Defense Committee of the ACLU, to Catherine East, Executive Secretary, Interdepartmental Committee on the Status of Women, Department of Labor (Nov. 16, 1966) (Pauli Murray Papers, MC 412, Box 40, Folder 706, on file with the Schlesinger Library, Radcliffe Institute, Harvard University); see also Willis v. Carson, $324 \mathrm{~F}$. Supp. 1144, 1149 (S.D. Miss. 1971) (declining to address the constitutional issue).

115. Esther Peterson, Memorandum for the Secretary [of Labor] (Feb. 16, 1966) (Esther Peterson Papers, MC 450, Box 54, Folder 1062, on file with the Schlesinger Library, Radcliffe Institute, Harvard University). 
White litigation effort. ${ }^{116}$ The meeting clearly was an attempt by Peterson to move beyond the divisive politics of the ERA and unify feminists behind a Fourteenth Amendment strategy built on the White victory. Kenyon, for one, enthusiastically accepted Peterson's invitation to a meeting that would "include Equal Righters," for, as Kenyon put it, "[w]e are all workers in the same vineyard." 117

\section{A "Philosophy of Continuity and Inclusiveness"}

While Peterson was attempting to consolidate momentum behind the Fourteenth Amendment, Pauli Murray and Alma Lutz of the NWP continued an exchange of views begun the previous winter as the White case was coming to trial. Murray and Lutz occupied the most moderate positions in their respective Fourteenth Amendment and ERA camps: Murray had never been opposed to the ERA in principle, while Lutz, though vehemently in favor of constitutional amendment, had never been hostile to Black civil rights, and was at least willing to engage in a dialogue about strategic options. Their correspondence reveals the extent to which Murray continued to sec the choice between an ERA and Fourteenth Amendment litigation as a purely strategic matter. She believed that the courts, steeped as they were in the emerging civil rights jurisprudence, would be receptive to the jury exclusion issue and, moreover, that women's organizations could unite around litigation but were not yet ready to coalesce behind a new constitutional amendment.

As her letters indicate, Murray was also profoundly attracted to the Fourteenth Amendment's symbolic association with racial justice. She immediately situated herself as a civil rights activist whose defining experience had been "the Negro struggle to implement the Fourteenth Amendment." 18 Because women's organizations were "hopelessly divided upon the Equal Rights Amendment," Murray wrote, "the quickest way to obtain the results the Equal Rights Amendment is intended to produce is to urge the courts to make clear that discrimination against women by the state or federal governments violates the Fifth and Fourteenth Amendments." 19 She summed up her position as follows:

I think there are enough women aroused about legal rights to bring cases through the courts; I do not believe enough of them are aroused to secure the passage of an Equal Rights Amendment. And so we differ not so much in our objectives as in our strategy. It is

116. Letter from Esther Peterson to Dorothy Kenyon (Apr. 13, 1966) (Esther Peterson Papers, MC 450, Box 54, Folder 1063, on file with the Schlesinger Library, Radcliffe Institute, Harvard University).

117. Letter from Dorothy Kenyon to Esther Peterson (Mar. 17, 1966) (Esther Peterson Papers, MC 450, Box 54, Folder 1063, on file with the Schlesinger Library, Radcliffe Institute, Harvard University).

118. Letter from Pauli Murray to Alma Lutz 1 (Dec. 9, 1965) (Pauli Murray Papers, MC 412, Box 97, Folder 1730 , on file with the Schlesinger Library, Radcliffe Institute, Harvard University).

119. Id. (emphasis added). 
just possible that through court interpretation the Equal Rights Amendment will be written into the Constitution. ${ }^{120}$

The White litigation, Murray added, "just may be the opening we have been looking for." 121

Murray also explained her strategic role in mediating between ERA advocates and opponents to achieve outcomes in line with those that Lutz sought. Murray wrote: "Some of us see our task as holding the line but not allowing ourselves to get isolated from the women who are still confused about how much equality they want. This is a difficult but necessary role." 122 In elaborating her strategic vision, Murray articulated what she called her "philosophy [of] continuity and inclusiveness," 123 urging Lutz and her NWP colleagues to "support us in this effort while pursuing your own independent goals." 124

Lutz and some of her NWP colleagues were encouraged by Murray's attitude. In January 1966, after Lutz forwarded her a copy of Murray's letter, Miriam Holden commended its "important expression of opinion" to Alice Paul. ${ }^{125}$ Writing baek to Murray, Lutz agreed that women should not harbor ill feelings with respect to their different approaches, but expressed frustration that women like Kenyon and Peterson were irredeemably opposed to the ERA as a result of "differences with the Woman's Party of long standing, dating back to suffrage days." 126 She wrote that "[i]f you good women would only put past prejudices behind you and get behind the Amendment, it would pass within the year."127

The Murray-Lutz correspondence continued after the February White ruling. Murray wrote to Lutz in March of what she called "a salutary byproduct of the [White v. Crook] victory"--a "movement in embryo to reconcile the various points of view within women's groups and to give honor to the pioneers who have kept the issue before the public," 128 undoubtedly a referenee to NWP oId-timers like Lutz, Alice Paul, and Emma Guffey Miller. She also expressed concern about "rumours that some women of the National Woman's Party persuasion have feared that the

120. Id.

121. Id.

122. Letter from Pauli Murray to Alma Lutz 1 (Jan. 16, 1966) (Pauli Murray Papers, MC 412, Box 97, Folder 1730 , on file with the Schlesinger Library, Radcliffe lnstitute, Harvard University).

123. Letter from Pauli Murray to Alma Lutz 2 (Mar. 15, 1966) (Mary Eastwood Papers, 83-M257, Box 5, Folder 56, on file with the Schlesinger Library, Radcliffe Institute, Harvard University).

124. Id.

125. Letter from Miriam Holden to Alice Paul (Jan. 29, 1966), microformed on NWP Papers, Misc 959, Reel 110 (Microfilming Corp. of Am.).

126. Letter from Alma Lutz to Pauli Murray (Apr. 21, 1966) (Pauli Murray Papers, MC 412, Box 97, Folder 1730, on file with the Schlesinger Library, Radcliffe Institute, Harvard University).

I27. Id.

128. Letter from Pauli Murray to Alma Lutz 1 (Mar. 15, 1966) (Mary Eastwood Papers, 83-M257, Box 5, Folder 56, on file with the Schlesinger Library, Radcliffe Institute, Harvard University). 
[White v. Crook] decision would hurt the chances of passage of an [Equal Rights Amendment]." 29 Again, post-White, Murray reiterated her view that feminists should be satisfied with any means that led to their desired end: "[W]e are all after a specific result: equal rights without discrimination on the basis solely of sex. If we can get it by court decision, we'll take it." However, if the Supreme Court could not be convinced, "there would be a constitutional gap which would have to be filled by a constitutional amendment." 130

\section{3. "An Integral Relation": The Unrealized Promise of the Jury Exclusion Issue}

In the end, none of the jury exclusion cases reached the Supreme Court. ${ }^{131}$ The failure of the jury service issue to produce the "definitive Court pronouncement" PCSW adherents sought had important consequences for feminism's constitutional destiny. Combined with Nixon's election in 1968 and concomitant expectations of increasing judicial conservatism, it moved feminist strategists one step closer to the eonclusion that an ERA might be necessary after all. ${ }^{132}$ Also, these cases had provided a compelling vehicle for connecting the civil rights and women's rights struggles under a universalist conception of the Fourteenth Amendment. Substantively, then, the failure of an instance of jury exelusion of African Americans and white women to become the landmark sex discrimination case under the Fourteenth Amendment represented a missed opportunity for jurisprudential convergence of the Black civil rights and women's rights causes.

Jury exclusion was a context in which the legal disabilities of African Americans and white women converged in a way that dramatized interconnections between race and sex discrimination. Kenyon and Murray, who were working within the ACLU to heighten its consciousness about women's rights issues, found in jury service discrimination a compelling case with which to plead their cause. In the South, they argued-both to their sometimes skeptical male colleagues and to the courts-there was "an integral relation between the exclusion of women and exclusion of Negroes

129. Id.

130. Id. at $1-2$.

131. The issue was eventually considered by the Court in Taylor v. Louisiana, 419 U.S. 522 (1975), in which a male defendant successfully challenged Louisiana's exemption of women from jury servicc on Sixth Amendment grounds.

132. The Burger Court did not prove to be the reactionary institution liberals feared, but rather had a mixed legacy, extending some Warren Court innovations and curtailing others. For an extended discussion, sce The Burger Court: Counter-Revolution or Confirmation? (Bernard Schwartz ed., 1998); The Burger Court: The Counter-Revolution that Wasn't (Vincent Blasi cd., 1983); see also Mark Tushnet, The Warren Court as History: An Interpretation, in THE WARREN Court in Historical and Political Perspective 1, 31 -34 (Mark Tushnet ed., 1993) (discussing the continuities and discontinuities between the Warren and Burger Courts). 
[from jury service]." 133 Not only did women's exclusion from this central rite of citizenship devalue their political identity, but, Murray and Kenyon argued, the absence of white and Black women from Southern juries had substantial material effects on the outcome of civil rights cases.

Jury service was also an issue that cut across boundaries of class, affecting women from all walks of life. Though the ERA embodied the same legal outcome Pauli Murray sought from Fourteenth Amendment litigation, the proposed amendment retained a symbolic association with white professional women single-mindedly devoted to formal equality and indifferent to the plight of poor women and women of color. As the next section argues, the increasing support for the ERA that resulted from limited litigation success coincided with a perceived shift away from prioritization of disadvantaged women's concerns. Furthermore, when political turmoil and increasing conservative preoccupation with the "rule of law" propelled Nixon into office in 1968, hopes of bringing a women's rights case before the Warren Court appeared dashed. The jury exclusion issue had seemed the perfect case to present to a Court whose reputation for creative constitutional interpretation was built largely upon its expansive Fourteenth Amendment rulings on racial issues. Now feminists would have to look elsewhere in their quest for constitutional change.

\section{D. "The Only Consistent Position": Consolidation of a Dual Constitutional Strategy, 1966-1970}

When the National Organization for Women (NOW) was born at a conference on employment discrimination in $1966,{ }^{134}$ legal progress was foremost on the group's agenda. Several of the group's founding members, including Pauli Murray, Richard Graham, and Aileen Hernandez, were attorneys who shared the indignation of Betty Friedan and other activists at the EEOC's failure to prioritize the enforcement of Title V1l's prohibition on sex discrimination. ${ }^{135}$ While NOW's "targets for action" in 1966-67 included the "support and encourage[ment of] women seeking to invoke their right to equal protection of the law under the United States Constitution," 136 the Organization did not immediately take a position on

133. Letter from Pauli Murray to Marguerite Rawalt (Feb. 2, 1966) (Pauli Murray Papers, MC 412, Box 59, Folder 999, on file with the Schlesinger Library, Radcliffe Institute, Harvard University).

134. For more on the founding of NOW, see FrEEMAN, supra note 90, at 71-75; BeTTY FriEDAN, It Changed My Life (2d ed. 1998); Harrison, supra note 16, at 192-206; Susan M. Hartmann, From Margin to Mainstream: American Women and Politics Since 1960, at 58-62 (1996).

135. Murray, for example, had suggested since 1964 that women "needed a private organization ... to make our point of view felt, something a little more attuned to the Space Age than the NWP." Letter from Pauli Murray to Marguerite Rawalt 3 (Apr. 14, 1964) (Mary Eastwood Papers, 83-M257, Carton 1, Folder 7, on file with the Schlesinger Library, Radcliffe Institute, Harvard University).

136. NOW, Targets for Action 1966-67, DRAFT (Oct. 26, 1966), microformed on NWP Papers, Misc 959, Reel 110 (Microfilming Corp. of Am.). 
the ERA. But by the end of 1967, after much internal discussion and dissension, the ERA had received top billing in NOW's Bill of Rights for Women.

Part I.D will examine feminist consolidation behind a dual constitutional strategy that both endorsed litigation for women's rights under the Fourteenth Amendment and sought a constitutional amendment to solidify women's equal status under the law. This consensus was not unanimously embraced, nor was it costless. One price exacted by the acceptance of a combined Fourteenth Amendment/ERA strategy was the reduction of feminist legal demands to their lowest common denominator-a constitutional amendment whose substantive sections retained wording not much different from that proposed by Alice Paul in the early I920s. In the process, some committed feminists, Murray included, came to feel betrayed by what they viewed as the elevation of white professional women's priorities at the expense of unity with other movements for social justice. Moreover, more expansive proposals for constitutional change fell by the wayside as NOW sought to frame an agenda around which a panoply of women's groups could unite.

Part I.D. 1 examines the controversy within NOW over the ERA, and the alternative models of constitutional change rejected in the quest for a unified feminist pro-ERA position. Part I.D. 2 traces the increasingly prevalent feminist conviction that constitutional change should be sought through a dual strategy of Fourteenth Amendment litigation and ERA advocacy by describing the dual strategy's ascendance in NOW, the BPW, and even the NWP. Finally, Part I.D.3 relates the triumph of the dual strategy within the ACLU, a longtime ERA opponent that had been, and would continue to be, a pivotal organization for women's rights advocacy.

\section{Constitutional Roads Not Taken: Human Rights Amendments and the Price of Unity}

In the heady early months of NOW's existence, feminists worked to define their legal agenda both within the new organization and with respect to establishcd women's groups and constituencies. Organizational documents reflect a barely contained excitement about the possibilities for legal breakthroughs and more general social change. NOW, many hoped, would put an end to the marginal status of women's rights on the national political agenda and give liberal feminists a platform from which to advance equality in employment, education, government, media imagery, reproductive rights, the family, and the economy.

From the beginning, NOW couched its mission in terms of cooperation between men and women to obtain benefits for both sexes and for American society generally. The organization's stated purpose was "to take action to bring women into full participation in the mainstream of 
American society now ... in truly equal partnership with men," and "to mobilize the political power of all women and men intent on our goals." 137 NOW's first members were not cultural radicals or neophytes in the battle for sex equality. Several, including former EEOC commissioners Hernandez and Graham, as well as Mary Eastwood, Caruthers Berger, and Catherine East, were current or former government employees or officials; some, like Caroline Davis and Dorothy Haener of the United Auto Workers (UAW), were labor union activists; and most, like Pauli Murray and Kay Clarenbach, had played prominent roles on various commissions investigating the status of women, including the PCSW and its descendants. ${ }^{138}$

True to her universalist predilections, Murray was intent on establishing partnerships between NOW, other women's groups, and civil rights organizations. ${ }^{139}$ To her, NOW presented an opportunity to unite individuals and groups concerned with the status of women and with other civil rights issues and to avoid the divisive battles of the past. She knew this to be a delicate task, particularly on the legal front, where protective labor legislation was still a thorny issue for women union leaders, many of whom now believed in the desirability of an ERA but had yet to convince their union colleagues. ${ }^{140}$ The ERA issue was unavoidable, however, and in early 1967 , NOW established a committee to study the legal rights of women under the federal Constitution. ${ }^{141}$ The committee included several longtime ERA supporters-Alma Lutz, Caruthers Berger, Marguerite Rawalt, and Inka O'Hanrahan, also of the NWP. Mary Eastwood was a key participant who had come to believe, since her service as technical secretary to the PCSW's CCPR and her collaboration with Murray on the "Jane Crow" article, that feminists should pursue a new amendment. Other members, such as Phineas Indritz and Morag Simchak, had profound misgivings about ERA advocacy. ${ }^{142}$

The NOW committee considered several options besides embracing or rejecting the ERA as drafted by Alice Paul decades earlier. Various

137. HARTMANN, supra note 134 , at 59 .

138. Id. at 58-59.

139. See, e.g., Minutes 2-4, NOW Executive Board (Nov. 20, 1966) (Betty Friedan Papers, Carton 44, Folder 1563, on file with the Schlesinger Library, Radcliffe Institute, Harvard University) (recording Murray's successful addition to the agenda of "NOW's relationship to other women's and civil rights organizations," and the subsequent passage of a motion to initiate "concerted action" with other interested groups).

140. FREEMAN, supra note 90, at 80; see also, e.g., Minutes of the First Board Meeting, NOW 4 (Oct. 30, 1966) (Betty Friedan Papers, Carton 44, Folder I55I, on file with the Schlesinger Library, Radcliffe Institute, Harvard University) (recording Murray's explanation to NOW members that they should tread warily before getting involved in lawsuits that risked outlawing maximum hours laws for women).

I4I. Minutes, NOW Board of Directors Meeting 6 (Feb. 22-23, I967) (Betty Friedan Papers, Carton 44, Folder I550, on file with the Schlesinger Library, Radcliffe Institute, Harvard University).

142. Minutes of National Conference of NOW 4-6 (Nov. I8-19, 1967) (Betty Friedan Papers, Carton 44, Folder 1550, on file with the Schlesinger Library, Radcliffe Institute, Harvard University). 
proposals were offered for discussion, including a "Human Rights Amendment," which provided that "[t]he right to equal treatment, without differentiation based on sex, shall not be denied by the United States or by any State," that "[n]o public funds shall be granted or loaned and no special tax exemption or privilege shall be accorded by the United States or by any State to any person who discriminates on the basis of race, color, sex, national origin, or ancestry," and that "[ $t]$ he right of a woman to terminate a pregnancy under medical supervision shall not be denied or abridged by the United States or by any State."143

One of the most daunting obstacles to such innovative approaches was the NWP's existing base of support for the ERA as drafted in the 1920s and modified in the 1940s. ${ }^{144}$ The NWP adamantly opposed even the smallest, nonsubstantive changes in the ERA's language. When Betty Friedan proposed that the words "equal treatment" be substituted for the phrase "equality of rights under the law," 145 Alice Paul and her minions quickly quashed this modest "New Amendment for a New Era" initiative. ${ }^{146}$ Other slight alterations in wording were also rejected out of hand. ${ }^{147}$

143. Human Rights Amendment, in Proposal for NOW (Jan. 1, 1967) (Mary Eastwood Papers, 83M257, Carton 3, Folder 12, on file with the Schlesinger Library, Radcliffe Institute, Harvard University).

144. The original text composed by Paul in 1923 read: "Men and women shall have equal rights throughout the United States and every place subject to its jurisdiction. Congress shall have power to enforee this article by appropriate legislation." Rights of Passage: The Past and Future of the ERA 121 (Joan Hoff-Wilson ed., 1986). After revisions in 1943, the amendment's text read:

Equality of rights under the law shall not be denied or abridged by the United States or by any State on aceount of sex. Congress and the several States shall have power, within their respective jurisdictions, to enforce this article by appropriate legislation. This amendment shall not require uniformity of legislation among the several States, the District of Columbia, the Territories, and possessions of the United States.

Id. The final ERA, as passed in 1972, retained the first sentence of the 1943 version, granted exclusive enforcement power to Congress, and provided that the amendment would take effect two years after ratification. Id. at 125 .

145. The proposed change was an effort to clarify that the ERA would permit no protective legislation for women.

The new language is more precise and therefore more sure. It is less susceptable [sic] to being watered down by the courts .... Under the new language there would be no issue of whether the particular sex classification were permissible in a given situation brought before the courts since by its very words, no such different treatment based on sex could be made by the government.

For Discussion Purposes Only: Proposal: That NOW Support a Constitutional Amendment, but with New Language (Apr. 21, 1967) (Mary Eastwood Papers, 83-M257, Carton 3, Folder 12, on file with the Schlesinger Library, Radcliffe Institute, Harvard University).

146. For an account of Paul's rejection of the proposal, see Letter from Amelia Fry to Mary Eastwood (Oct. 12, 1979) and attached oral history (Mary Eastwood Papers, 83-M257, Carton 3, Folder 12 , on file with the Schlesinger Library, Radeliffe Institute, Harvard University).

147. See, e.g., Harriet Bradford, Proposed Rewording of the Equal Rights Amendment (Spring 1967) (Betty Friedan Papers, Box 42, Folder 1486, on file with the Schlesinger Library, Radeliffe Institute, Harvard University); Letter from Alma Lutz to Betty Friedan (Mar. 13, 1967) (Betty Friedan Papers, Box 42, Folder 1486, on file with the Schlesinger Library, Radcliffe Institute, Harvard University) (rejecting Bradford's proposal); Letter from Alma Lutz to Betty Friedan (Apr. 24, 1967) (Betty Friedan Papers, Box 42, Folder 1486, on file with the Schlesinger Library, Radcliffe Institute, 
The NWP disdained any changes - in wording or underlying meaning - to the amendment it had championed for so long.

Their steadfast insistence on retaining the old ERA language reflected the NWP's distrust of NOW's more expansive agenda. Although NOW was staid and mainstream on the spectrum of late 1960s feminism, to the NWP-now composed primarily of much older women, some of whom had themselves participated in the suffrage struggle in their youth ${ }^{148}$ NOW was full of young upstarts with radical ideas about marriage, gender roles, and reproductive rights. Miriam Holden wrote to an NWP colleague in February 1967 of the need to "disassociate ourselves from the current wave of activity" concerning "problems of sexual or psychological supremacy." 149 Holden feared that "[t]he idea of "equal rights' ... ha[d] been debased," and that the burgeoning women's movement was producing a "mass fear that American women are seeking to pre-empt the masculine role in our society." 150 To stem the tide of these "negative emotional reactions," Holden argued that the NWP should "include the word legal...[e]ach time our Amendment is mentioned... [since] our Amendment is aimed solely at remedying the legal disabilities of American women."151

After meeting with Alice Paul and other NWP stalwarts, Eastwood became convinced that the most prudent course of action was for NOW to endorse the ERA and work in concert with the NWP and other pro-ERA groups. ${ }^{152}$ At the same time, NOW was coming under increasing pressure from other activists to endorse the existing language of the ERA. ${ }^{153}$ Alma Lutz wrote Betty Friedan a series of letters in 1967 strongly urging her to

Harvard University) ("With [eighty-eight supporting Senators and eighty-six House supporters] available, it would seem very foolish to introduce a different wording.").

148. For instance, in 1967, Miriam Holden would tum seventy-four, Alma Lutz seventy-seven, Emma Guffey Miller ninety-three, and Alice Paul eighty-two.

149. Letter from Miriam Holden to Miss Newell (Feb. 11, 1967), microformed on NWP Papers, Misc 959, Reel 110 (Microfilming Corp. of Am.).

150. Id.

151. Id.

152. A year earlier, Eastwood had been hesitant to suggest that NOW tackle the ERA issue right away, expressing her own preference that NOW "wait a year or two on the issue of a constitutional amendment until we see how well the courts can do under the Fifth and Fourteenth Amendments," though she did believe that raising the ERA issue in NOW "might serve to separate the women from the girls, i.e. those who believe in equality from those who "want to have their cake and eat it too." Letter from Mary Eastwood to Inka O’Hanrahan 2 (July 25, 1966) (Betty Friedan Papers, Box 42, Folder 1481, on file with the Schlesinger Library, Radcliffe Institute, Harvard University); see also Letter from Mary Eastwood to Betty Friedan (Aug. 1966) (Betty Friedan Papers, Box 42, Folder 1481, on file with the Schlesinger Library, Radcliffe Institute, Harvard University) (“Inka O'Hanrahan wrote asking my views on how to get the equal rights amendment through Congress.... She obviously assumed that anyone who is for women is for the amendment and suggested N.O.W. might urge its passage. 1 don't think Kay Clarenbach ... or Caroline Ware, e.g. would like that idea at all.").

153. Rupp and Taylor argue that the NWP's prompting was largely responsible for NOW's endorsement of the ERA in 1967. RUPP \& TAYLOR, supra note 14, at 182. 
convince NOW of the ERA's merits, ${ }^{154}$ and by the fall, NOW's Washington, D.C. chapter had passed a resolution giving unequivocal support to the amendment. ${ }^{155}$ On the other hand, Marguerite Rawalt, the PCSW's lone ERA supporter five years earlier, was hesitant. Her enthusiasm for the amendment remained undiminished, but she worried that a rejection of the ERA, coming from the well-publicized NOW, would be devastating for its chances. ${ }^{156}$ Further, Rawalt believed that a Fourteenth Amendment breakthrough might be forthcoming in the litigation to which she had, at age seventy-two, dedicated herself almost full-time. ${ }^{157}$ Pauli Murray, for her part, was principally concerned that NOW's endorsement of the ERA would alienate labor union women and isolate the issue of women's rights from broader civil rights and human rights goals.

Despite trepidation among some key members about raising the ERA issue at this early juncture, ${ }^{158}$ constitutional change and women's legal

154. See, e.g., Letter from Alma Lutz to Betty Friedan (Mar. 13, 1967) (Betty Friedan Papers, Box 42, Folder 1486, on file with the Schlesinger Library, Radeliffe Institute, Harvard University) ("The outlook for [the ERA] in the 90th Congress is good. Why let past prejudices stand in the way[?] The important thing is to let Congress know that women demand an Equal Rights Amendment."); Letter from Alma Lutz to Betty Friedan (Apr. 24, 1967) (Betty Friedan Papers, Box 42, Folder 1486, on file with the Schlesinger Library, Radcliffe Institute, Harvard University) ("[M]ay I make another plea by mail that NOW endorse the Equal Rights for Women Amendment."). In yet another appeal, Lutz wrote:

1 feel 1 must again remind you that test cases to bring about more up-to-date Supreme Court interpretations of the Constitution are only playing with the problem as they will not be a permanent solution, no matter how much Esther Peterson may recommend them. Only an amendment, writing no sex diserimination into the Constitution will wipe out the Common Law valuation of women ... . Why do you hold back from supporting this Amendment?

Letter from Alma Lutz to Betty Friedan (Aug. 19, 1967) (Betty Friedan Papers, Box 42, Folder 1486, on file with the Schlesinger Library, Radcliffe Institute, Harvard University).

155. National Capital Area NOW, Resolution (Nov. 19, 1967), microformed on NWP Papers, Misc 959, Reel 110 (Microfilming Corp. of Am.) ("WHEREAS, women have been unsuceessfully seeking equal rights under the Fifth and Fourteenth Amendments of the United States Constitution through litigation extending over a full century ... WHEREAS, the Equal Rights Amendment would unequivocally seeure the right to equal treatment under the law without differentiation based on sex.").

156. PATERSON, supra note 25, at 177.

157. Id.; see also Letter from Marguerite Rawalt to Betty Friedan, Kay Clarenbach, and Inka O'Hanrahan 2 (Nov. 21, 1967) (Betty Friedan Papers, Box 42, Folder 1491, on file with the Schlesinger Library, Radcliffe Institute, Harvard University) ("I am delighted that the Conference took its stand on the Equal Rights Amendment and on employment rights. [But] 1 was disappointed that the press eonference did not emphasize the work we have donc and are doing in the name of NOW in the courts.").

158. According to confidential notes prepared for Friedan the week before the November Conferenee, NOW's leadership was well aware of many contours of the impending confrontation, including the imminent departure of labor union women if NOW endorsed the ERA. Confidential Notes for Betty Friedan, President of NOW (Nov. 11, 1967) (Betty Friedan Papers, Box 42, Folder 1491, on file with the Schlesinger Library, Radcliffe Institute, Harvard University) ("Whatever may be the personal views of [UAW women], they are eompletely powerless to influence the UAW position at this point, and unless they are willing to give up their jobs, the presence of [other UAW leaders] at the NOW Conference will make it impossible for them to work with us."). They anticipated a variety of diversionary tactics on the part of ERA opponents, including proposals to delay the endorsement decision and support alternative language for the amendment, as well as dire predictions of eongressional defeat. Id. 
status topped the agenda at NOW's second annual conference in November. Organizers set aside the Saturday afternoon session for a special all-conference discussion of the ERA and abortion, the two most contentious issues facing the young organization. ${ }^{159}$ As expected, the debate was long and vigorous. UAW representatives Dorothy Haener and Caroline Davis requested that NOW delay its endorsement of the ERA and grant them more time to convince labor leaders of its merits, while Phineas Indritz warned that a new amendment had no chance of passing Congress and urged instcad the continued pursuit of litigation under the Fourteenth Amendment. ${ }^{160}$

Hoping to head off a direct confrontation between the remnants of protectionism and the growing equalitarian impulse-and, morcover, between women with deep loyalties to other causes and those for whom women's rights had become the primary preoccupation-Murray stepped in to assume her time-honored mediating role. ${ }^{161}$ In place of a resolution committing NOW to full and immediate support of the ERA, she made a substitute motion, which would have sent the pro-ERA resolution to local NOW chapters to study for a period of seven months before making a final decision among three altcrnatives: endorse the ERA as is, endorse an alternative amendment with different wording, or incorporate the ERA into a general Human Rights Amendment that would include other forms of discrimination alongside sex. ${ }^{162}$ As the conference minutes recorded, "much discussion followed," 163 but the Murray motion was only able to muster fifteen votes, while eighty-two voted against the substitute and for NOW's immediate endorsement of the ERA. ${ }^{164}$

With NOW's embrace of the ERA, feminism had taken a momentous step toward a dual constitutional strategy, one that would combine litigation under the Fourteenth Amendment with active advocacy for the ERA. But the price was high. As NOW leaders had anticipated, some labor union women felt compelled to resign from NOW's leadership, and Murray, the organization's strongest voice for collaboration with other civil rights

159. 1967 National Conference of N.O.W. Schedule (Nov. 1, 1967) (Betty Friedan Papers, Carton 44, Folder 1550, on file with the Schlesinger Library, Radcliffe Institute, Harvard University).

160. PAterson, supra note 25, at 180; Minutes of the NOW Conference (Nov. 18, 1967) (Betty Friedan Papers, Carton 44, Folder 1553, on file with the Schlesinger Library, Radcliffe Institute, Harvard University).

161. According to one set of minutes, Murray spoke straightforwardly of her concern that a strong stance on the ERA would "alienate organizations who have given us support until now." Minutes of the NOW Conference, supra note 160. Barbara Ireton of the Washington, D.C. chapter of NOW, which sponsored the resolution, retorted that NOW had the support of many organizations behind the ERA already. Id.

162. Minutes of National Conference of NOW (Nov. 18-19, 1967) (Betty Friedan Papers, Carton 44, Folder 1550, on file with the Schlesinger Library, Radcliffe Institute, Harvard University).

163. Id.

164. Id. 
causes, ${ }^{165}$ left the conference "deeply disillusioned." 166 Three days later, she wrote an anguished letter to Clarenbach, expressing her fear that a singleminded focus on the ERA would confine the movement "almost solely to 'women's rights' without strong bonds with other movements toward human rights." 167 Furthermore, Murray felt that such an approach "might develop into a head-on collision" with Black civil rights and other struggles. ${ }^{168}$ While Murray did not oppose the ERA per se, she felt that concentrating on the amendment in light of other groups' misgivings compromised the multiplicity of her own identity and her aspirations for the feminist movement. Murray told Clarenbach of her "inability to be fragmented into Negro at one time, woman at another, or worker at another."169 Although Murray remained in close touch with Mary Eastwood and other NOW activists, she decided to pursue her feminist legal agenda-including, eventually, explicit support for the ERA-within the ACLU's broader-based organization. ${ }^{170}$

The significance of NOW's endorsement of the ERA in 1967 went beyond its symbolic exclusion of voices like Murray's. ${ }^{171}$ In a very real

165. Aileen Hernandez and others also spoke out on behalf of building connections with racial minority groups. See, e.g., Letter from Aileen Hernandez to Muriel Fox (Oct. 21, 1967) (Betty Friedan Papers, Box 42, Folder 1484, on file with the Schlesinger Library, Radcliffe Institute, Harvard University) ("I still think NOW needs to find ways of gaining more appeal in the minority communities and perhaps Dollie [Robinson] and Pauli [Murray] can act as one bridge [as NOW Board Members].").

166. HARTMANN, supra note 25, at 189.

167. HARTMANN, supra note 25, at 190 (quoting Letter from Pauli Murray to Kathryn Clarenbach (Nov. 21, 1967) (Pauli Murray Papers, Box 51, Folder 899, on file with the Schlesinger Library, Radcliffe 1nstitute, Harvard University )).

168. Id.

169. Id.

170. Her estrangement from NOW must have been particularly devastating given the faith she had placed in women's solidarity. In January 1966, the fifty-five-year-old Murray had written exultantly to Eastwood that she had found a place within feminism that the civil rights movement had theretofore denied her:

[O]ur involvement in advancing the status of women gives us meaning and focus to our lives. My acute sensitivity to all of this stems directly from a kind of fateful exclusion from the inner circle of civil rights activities. In other words, having an intellect and an equalitarian point of view has been almost a handicap to me in finding a place in the civil rights struggle, as if it were a threat to male colleagues. No one, however, can deny me the right to speak out on behalf of women. Hooray for our side!

Letter from Pauli Murray to Mary Eastwood (Jan. 19, 1966) (Mary Eastwood Papers, 83-M257, Box 5, Folder 56, on file with the Schlesinger Library, Radcliffe lnstitute, Harvard University). She left NOW less than two years later, feeling "like a stranger in my own household ... passé, old, and declassed." Letter from Pauli Murray to Kathryn Clarenbach, supra note 167, quoted in HarTmanN, supra note 25, at 190.

171. Eastwood, for one, regretted that the ERA controversy at the 1967 Conference had "alienate[d] some of [NOW's] staunchest feminists and original organizers," including Murray. "[D]id we railroad [the ERA] through?" Eastwood wondered several months later. If so, Eastwood said, she and others had done so because they were "running scared and the principle [was] desperately important" to them. "What 1 am trying to say," she wrote to Murray, "is that I am not sorry for what we did, but I wish you were all actively working with us. Had we known we could win by such a tremendous margin, we could have been more conciliatory, kind and patient." But Eastwood also 
sense, the conference vote constricted the horizon of constitutional possibilities feminists would pursue in the following decade. In choosing to endorse the model of women's rights embodied by the ERA, NOW rejected alternative formulations of sex discrimination as enmeshed in other forms of inequality, extending beyond formal state action, and requiring an explicit constitutional guarantee of reproductive freedom. ${ }^{172}$ Instead, NOW's resolution enshrined the articulation of equality the NWP had promoted for so many decades, complete with its isolation from racial and other forms of discrimination, as well as its separation from reproductive rights. As a result, NOW lost many women who found themselves unable conscientiously to sustain their loyalties to other causes while committing themselves to NOW's vision of women's rights. At the same time, NOW was also on the verge of spawning more radical offshoot groups of mostly younger women who could not abide NOW's cultivation of a staid, mainstream, non-militant image. ${ }^{173}$

NOW did not, of course, dissociate itself from abortion rights-far from it. Indeed, the discussion immediately following the Organization's endorsement of the ERA at the 1967 conference concluded with a resounding, though initially controversial, endorsement of women's reproductive freedom and a call for the repeal of laws criminalizing abortion. ${ }^{174}$ But as a constitutionaI matter, NOW adopted a view of reproductive rights as separate from legal equality under an ERA. Later, as feminists assiduously built the ERA's legislative history, and as they promoted its ratification in the wake of the controversial Roe $v$. Wade decision, they were careful to reassure skeptics that the amendment in no way implicated abortion rights. ${ }^{175}$

acknowledged that if NOW had not endorsed the ERA, the organization would have lost her support. "Had we lost," she wrote, "l would not be in NOW, but a new more militant organization would have been formed." Letter from Mary Eastwood to Pauli Murray (May 27, 1968) (Mary Eastwood Papers, 83-M257, Carton 1, Folder 4, on file with the Schlesinger Library, Radcliffe Institute, Harvard University).

172. In addition to "Human Rights Amendments" that encompassed multiple issues, NOW considered a freestanding reproductive freedom amendment that read, "The right of a woman to prevent conception and with proper medical safeguards to terminate her pregnancy shall not be denied or abridged by the United States or by any state." According to its proponents, "The effect of this amendment would be to nullify all existing state criminal abortion laws, leaving the question of whether or not to have an abortion a matter for the woman herself, rather than the government, to decide." NOW, The Right of a Woman to Determine Hcr Own Reproductive Process, Document II (Betty Friedan Papers, Carton 44, Folder 1553, on file with the Schlesinger Library, Radcliffe Insitute, Harvard University).

173. For more on the splintering of new groups led by disaffected NOW members, see ALICE Echols, Daring to Be BaD: Radical Feminism in AmeriCa, 1967-1975, at 167-69 (1989); HARTMANN, supra note 134, at 62-66; FREEMAN, supra note 90, at 81-83; RUTH Rosen, THE WorLD Split Open: How the Modern Women's Movement Changed America $81-89$ (2000).

174. Minutes of National Conference of NOW, supra note 162.

175. See, e.g., MANSBridge, supra note 9, at 122-28; Donald G. Mathews \& JANe Sherron De Hart, Sex, Gender, and the Politics of ERA 158 (1990). 
The Human Rights Amendment did enjoy a brief renaissance in 1968 when some NOW members attempted its resurrection, but Mary Eastwood recognized its dismal prospects for success. The NWP and other long-time ERA supporters, she realized, were vehemently opposed to any changes to the ERA's text. ${ }^{176}$ In fact, many of these women were deeply uncomfortable associating issues such as reproductive freedom and discrimination against racial minorities with women's rights under the Constitution. It was these NWP stalwarts who had labored for so many years to pass Alice Paul's ERA, and though a new wave of feminism rendered their style of advocacy increasingly obsolete, they successfully clung to the amendment's original text and thereby ensured that their legal legacy would linger long after the NWP was a dead letter.

\section{2. "The ERA Need Not Compete with the Fourteenth Amendment": The Dual Strategy Ascendant}

Pauli Murray's profound alienation from NOW notwithstanding, the strategic approach to constitutional change she had articulated to Alma Lutz began to win adherents within NOW and among some feminists who had long supported the ERA. A consensus was developing around the proposition that Fourteenth Amendment litigation and agitation for a constitutional amendment could and should be pursued simultaneously. In NOW, in the BPW, and even, to some extent, within the NWP, the years 1967 and 1968 saw an unprecedented articulation of this dual constitutional strategy.

A 1967 debate within the BPW highlighted the controversial nature of any dual approach within an organization that had long supported the ERA. The dispute centered on whether the BPW's platform should include, in addition to an endorsement of the ERA, a provision "encourage[ing] judicial determination of existing legislation." ERA advocates within the BPW urged that the "judicial determination" clause be excluded from the platform, fearing that any qualifying clause would "dilute" the organization's "clear-cut position" on constitutional

176. See Letter from Mary Eastwood to Jean Witter (Sept. 2, 1968) (Mary Eastwood Papers, 83M257, Box 4, Folder 50, on file with the Schlesinger Library, Radcliffe Institute, Harvard University). Pauli Murray persisted in offering more expansive alternatives to the ERA until as late as 1970. See Letter from Pauli Murray to Editor, Boston Globe (Aug. 24, 1970) (Pauli Murray Papers, MC 412, Box 86, Folder 1497, on file with the Schlesinger Library, Radcliffe Institute, Harvard University) (suggesting an amendment that would "prohibit discrimination against any person based upon age, color, economic status, national origin, political belief, race, religion, sex, social status or any other non-merit factor," and would "apply not only to the United States or any State but also to private action").

177. Letter from Margaret V. Donnelly, Past President, Delaware Federation of BPW, to Hazel Palmer, Legislation Steering Committee, BPW (July 17, 1967), microformed on NWP Papers, Misc 959, Reel 110 (Microfilming Corp. of Am.). 
amendment. ${ }^{178}$ They failed, and the BPW went on record as supporting multiple paths to women's legal equality. ${ }^{179}$

Meanwhile, some NWP members were having second thoughts about the Party's single-minded approach to the ERA. In 1967, Caruthers Gholsen Berger, an attorney who maintained her active membership in the NWP after joining NOW the previous year, proposed revisions to the NWP's primary position statement on the ERA: "Questions and Answers on the Equal Rights Amendment." 180 The original "Questions and Answers" had taken the position that the existing federal Constitution excluded women from its coverage and declared the quest for a favorable Fourteenth Amendment ruling hopeless. ${ }^{181}$ Berger's suggested revisions included the deletion or substitution of all statements in "Questions and Answers" that undermined women's attempts to encourage the judicial reinterpretation of the Fourteenth Amendment. "The ERA," she declared, "need not compete with the 14th amendment."182

Mary Eastwood, still a DOJ attorney and now one of NOW's primary legal strategists, most elaborately and self-consciously articulated the new dual constitutional strategy. By the fall 1967 NOW national meeting, Eastwood had grown impatient with entrenched attitudes that pitted the two constitutional strategies against one another. She wrote to Murray that she "hope[d] everyone doesn't come to the conference with their same old prejudices for and against the amendment. If anyone says women aren't persons under the 14th amendment, or that the ERA can't pass because it hasn't passed since 1923, I think I will scream."183 Eastwood had come to believe that, rather than being at cross-purposes, the two strategies

178. Id.

179. NWP official Margery Leonard saw Murray's hand in the controversy, remarking to Party Chairman Mary Birckhead that Murray was "doing a fine job of sabotage." Letter from Margery Leonard to Mary Birckhead (July 20, 1967), microformed on NWP Papers, Misc 959, Reel 110 (Microfilming Corp. of Am.). NWP member Nina Horton Avery attended the BPW convention with the sole purpose of persuading the group to exclude from their plank the "qualifying verbiage" she believed would compromise the ERA effort. Letter from Nina Horton Avery to Alice Paul and Mary Birckhead (Aug. 1967), microformed on NWP Papers, Misc 959, Reel 110 (Microfilming Corp. of Am.).

180. National. Woman's Party, Equal Rights Amendment: Questions and Answers, Oct. 2, 1962 (Margery C. Leonard ed., 4th ed. 1963), S. Doc. No. 87-162 (1962) [hereinafter NWP, Questions AND ANSWERS, Oct 2, 1962].

181. NWP, QUESTIONS AND ANSWERS, Oct 2., 1962, supra note 180. See also Law Suits vs, the Equal Rights for Women Amendment, NWP BulLETIN, July-Aug. 1967, at 1-5 (Mary Eastwood Papers, 83-M257, Carton 3, Folder 14, on file with the Schlesinger Library, Radcliffe 1nstitute, Harvard University) (taking the same position as late as the summer of 1967).

182. Caruthers G. Berger, Comments on Questions and Answers on the Equal Rights Amendment (Sept. 22, 1967), microformed on NWP Papers, Misc 959, Reel 110 (Microfilming Corp. of Am.) (emphasis in original).

183. Letter from Mary Eastwood to Pauli Murray 2 (Oct. 26, 1967) (Mary Eastwood Papers, 83M257, Carton 3, Folder 12, on file with the Schlesinger Library, Radcliffe Institute, Harvard University). 
complemented one another. She declared to Murray that "[b]eing for pursuing the '14th amendment approach' [and] being for the ERA is the only consistent position." 184 Eastwood explained her views in a document prepared earlier for NOW:

As a matter of tacktics [sic], even if the ERA fails to pass, vigorously pushing for it will show women are demanding equal rights and responsibilities under the law by the most drastic legal means possible - a constitutional amendment. The effect, provided we make clear we think [the] $14^{\text {th }}$ [amendment] properly interpreted should give women [the] same unqualified protection, would be to improve our chances of winning 14th amendment cases. ${ }^{185}$

In another important statement circulated within women's rights organizations, Eastwood formalized the dual strategy, emphasizing that ERA advocacy and litigation under the Fourteenth Amendment were complementary endeavors and that both were crucial to the expeditious achievement of equality. ${ }^{186}$ By 1968 , the dual approach was the more-or-less official position of NOW. ${ }^{187}$

In the new climate of feminist mobilization and concomitantly increasing publicity, ${ }^{188}$ the ERA had become a promising focal point for women's rights activism. Still, feminist strategists were far from ready to abandon the Fourteenth Amendment approach, which held its own promise both for the achievement of concrete results and as an enticement to feminists still opposed to an ERA. Indeed, some, like Marguerite Rawalt, devoted themselves wholeheartedly to litigation under the Fourteenth Amendment as well as under Title VII even as they continued to advocate an ERA. Strategists had made great strides in building support for a dual

184. Id. (" $[\mathrm{T}]$ he more support [there] is for a new amendment, the better the chances for winning under the 14 th ... . [T] he converse is also true: winning under the 14th improves chances for [ERA] passage.").

185. Mary Eastwood, Proposal for NOW (Jan. 1, 1967) (Mary Eastwood Papers, 83-M257, Carton 3, Folder 12, on file with the Schlesinger Library, Radcliffe Institute, Harvard University) (emphasis added).

186. Mary O. Eastwood, Constitutional Protection Against Sex Discrimination: An Informational Memorandum Prepared for the National Organization for Women (NOW) Regarding the Equal Rights Amendment and Similar Proposals (Nov. 1967), microformed on NWP Papers, Misc 959, Reel 110 (Microfilming Corp. of Am.).

187. NOW, NOW Bill of Rights for 1968, microformed on NWP Papers, Misc 959, Reel 111 (Microfilming Corp. of Am.) (describing the ERA as the top priority); Jean Witter, Suggested Future Directions for N.O.W. (July 20, 1968) (Mary Eastwood Papers, 83-M257, Box 4, Folder 50, on file with the Schlesinger Library, Radcliffe Institute, Harvard University) (announcing the intention to continue providing financial and legal support for Fourteenth Amendment litigation).

188. FREEMAN, supra note 90 , at 148-50; HARTMANN, supra note 134, at 66; Rosen, supra note 173, at 298. Both Freeman and Rosen note that press coverage of the women's movement became more sympathetic in the late 1960 s as female journalists sent to cover movement events often wrote of their experiences as conversions to feminism. FreEman, supra note 90, at 114; Rosen, supra note 173, at 298. 
strategy among ERA proponents, convincing them that support for litigation under the Fourteenth Amendment was no longer a euphemism for antiERA sentiment.

\section{3. "New Tools for the Tools that Have Failed You": The Dual Strategy Triumphant}

Now that NOW, the BPW, and at least one contingent of the NWP had coalesced around the dual approach, all that remained was to persuade the remaining protectionists-and women's rights skeptics-of the need for an equalitarian approach. Though disenchantment with NOW had provoked her departure from its leadership, Pauli Murray remained a stalwart member of the ACLU Equality Committee, ${ }^{189}$ and it was there that she resolved to continue her efforts on behalf of women's rights. ${ }^{190}$ In early 1968 , shortly after her painful experience at NOW's national meeting, Murray wrote to Eastwood that she had undertaken a campaign within the ACLU to "develop a clean cut statement which would harmonize with our position in 'Jane Crow' and eliminate [support for] 'differential social legislation." "191 She also hoped the Equality Committee would "eliminate reference to opposition to a special constitutional amendment and simply take a positive vicw of the 14th amendment and oppose legislation based on sex per se." 192 But, Murray recognized, "This may not be easy to do in view of the long history of ACLU opposition to the Equal Rights Amendment."193

Murray was correct in her prediction that convincing the ACLU to embrace sex egalitarianism would be an uphill battle. As historian Susan Hartmann has recounted, the ACLU tended to discount the importance of women's rights on the one hand and cling to protective labor legislation on

189. Murray had served on the Equality Committee since early 1966. Minutes, ACLU Equality Committee (Feb. 3, 1966) (Pauli Murray Papers, MC 412, Box 54, Folder 943, on file with the Schlesinger Library, Radcliffe Institute, Harvard University) (introducing Murray as new committee member).

190. See, e.g., Minutes, ACLU Equality Committee 4 (Nov. 30, 1967) (Pauli Murray Papers, MC 412, Box 54, Folder 943, on file with the Schlesinger Library, Radcliffe Institute, Harvard University) (reporting Murray's urging that the ACLU "recognize that classification by race and sex are equally immoral. For many years the Union has taken the position that a new amendment for women's rights is not necessary. If not, it is time for the Union to get a case to the Supreme Court recognizing that women are entitled to employment on the basis of individual merit."); Minutes, ACLU Equality Committee (Dec. 28, 1967) (Pauli Murray Papers, MC 412, Box 54, Folder 943, on file with the Schlesinger Library, Radcliffe Institute, Harvard University) [hereinafter Minutes, ACLU Equality Committee (Dec. 28, 1967)] (urging the ACLU to reconsider its policy on protective legislation and adopt an equalitarian approach).

191. Letter from Pauli Murray to Mary Eastwood (Jan. 25, 1968) (Mary Eastwood Papers, 83M257, Carton 1, Folder 4, on file with the Schlesinger Library, Radcliffe Institute, Harvard University).

192. Id.

193. Id. 
the other. ${ }^{194}$ Responding to the rising tide of masculinism in certain strands of the civil rights movement, ${ }^{195}$ and often seeing the fight against sex discrimination as diverting resources from the battle for racial equality, ${ }^{196}$ the men who dominated the ACLU leadership explicitly prioritized the empowerment of Black men in the mid-1960s, leaving women's concerns for later resolution. ${ }^{197}$ They also worried that opposing protective legislation for women would undermine the ACLU's relationship with labor organizations that supported these laws. ${ }^{198}$

In short, Murray's role in women's organizations had been to reconcile many feminists' commitment to civil rights and labor causes with others' single-minded focus on women's rights. Now, in the ACLU, she found herself emphasizing the compatibility of sex equality with the ACLU's primary goals and allegiances, to which women's rights had often been tangential. In doing so, she had a powerful ally in Dorothy Kenyon, who had long promoted women's rights within the ACLU even as she opposed the ERA and supported protective labor legislation. ${ }^{199}$ By the late I960s, Murray had convinced Kenyon that differential protective laws for men and women were undesirable; ${ }^{200}$ accordingly, Kenyon increasingly

194. HARTMANN, supra note 25, at 72-73. Hartmann observes that the ACLU "adopted a feminist agenda" only "because of the deliberate efforts of card-carrying feminists to infiltrate and capture it." Id. at 56 .

195. For more on the gender ideologies of the Black Power movement, see Elaine Brown, A Taste of Power: A Black Woman's Story (1992); Paula Giddings, When and Where I Enter: The Impact of Black Women on Race and SeX in America 314-24 (1984); Jacqueline Jones, Labor of Love, Labor of Sorrow: Black Women, Work, and the Family from Slavery To THE Present 310-21 (1985). Also influential during this period was the Moynihan Report, which attributed the "breakdown" of African-American families in part to an enduring tradition of Black matriarchy. Office of Policy Planning and Research, U.S. Dep't of Labor, Moynihan Report, The Negro Family: A Case for National Action (1965). For a contemporary review of the debate surrounding the Moynihan Report, see Lee Rainwater \& William L. Yancey, The Moynihan Report and the Politics of Controversy (1967). For historians' perspectives, see Giddings, supra, at 325-35; JONES, supra.

196. See, e.g., Minutes, ACLU Equality Committee (June 6, 1968) (Pauli Murray Papers, MC 412, Box 54, Folder 943, on file with the Schlesinger Library, Radcliffe Institute, Harvard University) (describing debate over ACLU priorities in which Murray argued against her colleagues' insistence that combating racial discrimination was more important than attacking sex discrimination).

197. See, e.g., Minutes, ACLU Equality Committee 4 (Dec. 28, I967), supra note I90 ("[CORE director Floyd] McKissick noted that the circumstances in 1967 are changed. For example, CORE's Board of Directors has decided that black power is the method to be used to bring about equality. Thus, at the moment CORE is emphasizing black male power, and tomorrow will concentrate on the equality of women."); see also KERBER, supra note 25, at 195-96 (discussing McKissick's comments and Murray's response).

198. HARTMANN, supra note 25 , at $72-73$.

199. See, e.g., Memorandum from Dorothy Kenyon to ACLU Board Members, Re: Restatement of ACLU Position in Favor of Women's Rights (June 15, 1955) (Dorothy Kenyon Papers, Box 30, Folder 17, on file with the Sophia Smith Collection, Smith College).

200. As Kenyon wrote,

As for our position on Constitution-we believe XIV Amendment includes women in its coverage of non-discrimination (with permission for differential legislation if needed to effect genuine rather than mathematical equality). We also agree (at least Pauli $M$. and 1 do ...) 
emphasized the inherent virtues of gaining a favorable interpretation of the Fourteenth Amendment, which, she maintained, was the appropriate constitutional provision in which to locate sex equality. In March 1970, she wrote to an ACLU colleague:

I believe that a separate amendment for women alone (as though they weren't even "people" within the meaning of the constitution but a second class s[la]ve type of worm) would be denigrating and degrading (as well as difficult to evaluate or fathom the meaning of in constitutional terms). I therefore hang my hat on the 14th Amendment. ${ }^{201}$

Even Kenyon, however, grew frustrated with the slow pace of change in attitudes toward women's rights, expressing her exasperation in an April 1970 letter: "I know exactly how the Black Panthers feel, ignored[,] passed over, segregated (intellectually at least), and frustrated until they are ready to kilI."202 In June, Kenyon wrote to Betsy Nolan that while focusing on the Fourteenth Amendment was her preferred strategy, "in the meantime it's worth passing the equal rights amendment if only to stir up the men." 203

Before I970, Murray, Kenyon, Eastwood, and other sympathetic parties were mostly thwarted in their efforts to make sweeping changes in ACLU policy. ${ }^{204}$ But in 1969 , the EEOC interpreted Title VII to prohibit protective legislation for women only. This removed one of the few remaining barriers to ERA support, ${ }^{205}$ providing pro-equality forces within the ACLU with a new weapon in their arsenal of arguments for an egalitarian policy. ${ }^{206}$ As feminist groups, divided over many other aspects of their

that the differentiation into 'men' and 'women' is no longer a reasonable one, if it ever was, and that the use of the elassification 'women' qua 'women' is unfair and in itself unconstitutional.

Letter from Dorothy Kenyon to Harriet Pilpel (Feb. 7, 1968) (Dorothy Kenyon Papers, Box 29, Folder 11 , on file with the Sophia Smith Collection, Smith College).

201. Letter from Dorothy Kenyon to Louise Noun, ACLU (Mar. 26, 1970) (Dorothy Kenyon Papers, Box 29, Folder 1, on file with the Sophia Smith Collection, Smith College).

202. Letter from Dorothy Kenyon to Rolland O'Hare 1-2 (Apr. 20, 1970) (Dorothy Kenyon Papers, Box 29, Folder 1, on file with the Sophia Smith Collection, Smith College).

203. Letter from Dorothy Kenyon to Betsy Nolan, ACLU (June 29, 1970) (Dorothy Kenyon Papers, Box 29, Folder 1, on file with the Sophia Smith Collection, Smith College).

204. See, e.g., Letter from Pauli Murray to Mary Eastwood (Jan. 3, 1969) (Mary Eastwood Papers, 83-M257, Carton 1, Folder 4, on file with the Schlesinger Library, Radcliffe Institute, Harvard University) ("[T]he ACLU Board met, rejected [20-4] our entire statement and adopted [a statement less favorable to the dual strategyl .... [T] he male bigotry was too strong to overcome. With this statement, we have moved hardly an inch, but it does get rid of a lot of the verbiage in the former policy statement we were trying to replace.").

205. HARTMANN, supra note 25 , at 74 .

206. See, e.g., Memorandum from Susan Deller Ross, ACLU Position on Sex Discrimination and Protective Legislation (Mar. 17, 1970) (Pauli Murray Papers, MC 412, Box 55, Folder 958, on file with the Schlesinger Library, Radcliffe Institute, Harvard University).

[W] hen the Board reached its 1968 decision [to reject the equalitarian proposal], the effect of

Title VII [on protective laws]... was not known. In light of new developments and 
agendas, managed to coalesce around the ERA, Murray and Kenyon were inspired to declare openly their support for a new constitutional amendment. Murray wrote a forceful memorandum in March 1970 "urg[ing] as strongly as 1 can that ACLU not testify in opposition to the [ERA],"207 then before Congress. She reiterated her support for the Fourteenth Amendment approach, but wrote that she did not "believe today that the alternative of the use of the Fourteenth Amendment is a sufficient basis for strong opposition to the proposed Equal Rights Amendment."208

Murray made three interrelated arguments to the ACLU urging the group to drop its opposition to the ERA and embrace a dual constitutional strategy. First, she asserted, given the EEOC's clarification of Title VII's applicability to sex-differentiating protective legislation, "the basis on which ACLU has rested its traditional opposition to the Equal Rights Amendment fails." 209 Second, Murray noted that recent developments had rendered the Fourteenth Amendment strategy somewhat less promising, and that it was only a matter of time before Nixon packed the Court with strict constructionists likely to be less than sympathetic to expansive interpretations of the Constitution. ${ }^{210}$

Finally, Murray turned what had once been her chief argument for pursuing constitutional change through the Fourteenth Amendment into an impetus for acquiescing to the ERA proponents:

The most potent reason for not oppos[ing] the Equal Rights Amendment in the civil rights climate of 1970 is that, by taking a negative position, ACLU will not be able to avoid the impression that it is denying the proposition that civil rights are indivisible and that wherever discrimination is accepted against one disadvantaged group all others are in jeopardy. ${ }^{211}$

While previously she had embraced the Fourteenth Amendment approach as the best means of linking Black civil rights and women's rights goals, now that feminists were mobilizing behind an ERA, Murray believed that a

clarification of Title VIl by the courts and the Equal Employment Opportunity Commission (EEOC) and a considerable upsurge in complaints from women to the Union and to other organizations concerning discrimination, the Board is being asked to review its policy in this area.

Id. at 2 .

207. Memorandum from Pauli Murray to ACLU Equality Committee, Re: ACLU Position on Sex Discrimination 2 (Mar. 30, 1970) (Pauli Murray Papers, MC 412, Box 55, Folder 959, on file with the Schlesinger Library, Radcliffe Institute, Harvard University) [hereinafter Memorandum from Murray (Mar. 30, 1970)] (emphasis added).

208. Id.

209. Id. at 2-3.

210. Id. at 3. Kenyon, too, was chagrined by the prospect of Nixon appointees on the Court. See HaRTMANN, supra note 25, at 80; Letter from Dorothy Kenyon to Larty Speiser (June 3, 1971) (Dorothy Kenyon Papers, Box 29, Folder 2, on file with the Sophia Smith Collection, Smith College).

211. Memorandum from Murray (Mar. 30, 1970), supra note 207, at 3. 
universalist human rights approach required civil rights organizations to open their minds and their agendas to a new constitutional amendment.

Murray enlisted the help of Kenyon, who then declared her support for the ERA in a memorandum to the ACLU Board: "We still approvc of the XIV Amendment approach," Kenyon wrote for herself and Murray. "I think we all do. But in spite of heroic efforts on the part of women as well as of ACLU, the Supreme Court has consistently rejected us as having no place under it." 212 Noting the failure of White v. Crook, the ACLU's primary effort in the women's rights area, to reach the Court, Kenyon and Murray emphasized the likely ideological bent of upcoming judicial appointments under the Nixon administration. "There comes a time when you cannot wait any longer, when you must find new tools for the tools that have failed you," Kenyon wrote. "This I believe is such a time."214 Six days later, the ACLU Board endorsed the ERA. ${ }^{215}$

By 1970 , then, most legal feminists had reached a consensus that the constitutional change they sought could and should be pursued simultaneously through the dual strategy. For the protectionist stalwart Esther Peterson, conversion would take a little more time, but when she finally endorsed the ERA in 1971, it was with characteristic graciousness. She wrote to longtime ERA advocate Rep. Martha Griffiths in October that "[a]fter much soul searching," she had "come to the conclusion that the time for waiting for court action is past and enactment of the equal rights amendment would be a constructive step." 216 She continued:

212. Memorandum from Pauli Murray \& Dorothy Kenyon to the Board of the ACLU, Re: Women's Rights. The Equal Rights Amendment: Should We Favor lt, and If So, Why? (Sept. 24, 1970) (Pauli Murray Papers, MC 412, Box 55, Folder 956, on file with the Schlesinger Library, Radcliffe Institute, Harvard University); see also Memorandum from Dorothy Kenyon to the ACLU Board of Directors, Re: Why the Equal Rights Amendment for Women? 2 (Dec. 1, 1970) (Pauli Murray Papers, MC 4I2, Box 55, Folder 956, on file with the Schlesinger Library, Radcliffe Institute, Harvard University) ("The Supreme Court has not just ignored us, as Professor Paul Freund seems to think . . but has rejected us outright.").

2I3. Memorandum from Pauli Murray \& Dorothy Kenyon to the Board of the ACLU, supra note 212 ("The courts, facing a large number of new appointments to the judiciary by a president committed to strict constructionists, having failed to make such a radical change in policy in the 1960's, is [sic] likelier still not to make it in the years to come."); see also Memorandum from Dorothy Kenyon to the ACLU Board of Directors, supra note 212, at 1-2 ("A strict construction treatment of the Constitution on this point would throw us back into the mediaeval days of Blackstone.... Yet it is a strict construction mood that seems to prevail today.").

214. Memorandum from Pauli Murray \& Dorothy Kenyon to the Board of the ACLU, supra note 212.

215. Press Release, ACLU (Oct. 2, I970) (Mary Eastwood Papers, 83-M257, Carton 3, Folder 12, on file with the Schlesinger Library, Radcliffe Institute, Harvard University). Hartmann shows that the change in ACLU policy was due not only to external events and to the internal pressures from Murray and Kenyon, but also to grassroots organization on behalf of the ERA by women in the ACLU's local affiliates. HARTMANN, supra note 25 , at 75 .

2I6. Letter from Esther Peterson to Martha Griffiths I (Oct. I2, 1971) (Esther Peterson Papers, MC 450, Box 54, Folder I061, on file with the Schlesinger Library, Radcliffe Institute, Harvard University); see also KESSLER-HARRIS, supra note 25, at 289. 
It is difficult for me to make this statement. ... [But h]istory is moving in this direction and I believe women must move with it. ... My congratulations to you ... for taking a courageous and foresighted position. I am happy that I can now share it with you. ${ }^{217}$

In uniting around the ERA, protectionists and equalitarians did not relinquish all hope of constitutional change through judicial reinterpretation; rather, feminists calculated that pursuing improvements in women's legal status through a constitutional amendment was a goal complementary to ongoing litigation efforts.

The decision to pursue a dual constitutional strategy was the result of a long, difficult process of deliberate coalition-building by strategists like Murray, Eastwood, and others. Equalitarians and protectionists alike had invested the choice between amendment and judicial reinterpretation with symbolic and substantive meanings that inhibited the formulation of a coherent legal agenda until the late 1960s. Historically grounded negative preconceptions that linked the ERA with formalism, class privilege, racism, and disregard for the needs of the average working woman competed with disdain for the Fourteenth Amendment as an ineffectual tool of protectionist evasion or a deceptive ploy by activists more concerned with racial problems than with eradicating sexism. In the end, the historical affiliations and affinities of certain individuals and groups with one mode of constitutional change or the other fostered a continuing distrust that may have discouraged ERA proponents from considering more expansive constitutional agendas. Choices legal feminists made about which methods of constitutional change to pursue thus had considerable substantive, as well as strategic, consequences for the shape of the 1970s debate over legal equality for women, and for the constitutional landscape we encounter today.

II

IMPlementing the Dual Constitutional Strategy:

The Dilemmas of AdVocaCy

Part I recounted the process whereby women's rights leaders overcame entrenched divisions to unite behind the dual constitutional strategy during the course of the 1960s. Part II extends the historical narrative into

217. Id. at 1-2. Murray was similarly gracious in a letter to Betty Friedan, mending fences damaged at the 1967 NOW Confcrence.

For some time l've meant to drop you a note to tell you how much 1 appreciate the yeoman service you have performed in getting the women's movement on the march again. So oftcn we accept the gifts of one's genius and do not remember to express our gratitude to the giver ... l'm sorry we rubbed one another the wrong way in the heat of the game .... [I] just know that if you admire and respect my mind as much as 1 do yours, we are truly soul sistcrs.

Letter from Pauli Murray to Betty Friedan (June 20, 1970) (Betty Friedan Papers, Box 42, Folder 1488, on file with the Schlesinger Library, Radcliffe Institute, Harvard University). 
the $1970 \mathrm{~s}$, exploring the dilemmas feminist legal strategists faced once they determined to seek both judicial reinterpretation of existing constitutional provisions and an ERA.

The years 1970 and 1971 were momentous ones for the feminist movement. For the first time, Congress was considering the ERA against a backdrop of mobilized women's rights agitation, forcing feminists to articulate publicly their conception of women's status under the federal Constitution. Against challenges from both anti-ERA and sympathetic legislators, feminists defended their dual constitutional strategy to the hilt. Both prongs of their strategy began to bear fruit as legal feminism gained increasing momentum in Congress and in the courts. Still, the dual strategy also presented quandaries for advocates whose simultaneous pursuit of two modes of change quickly became something of a double-edged sword. The resulting paradoxes, and how feminists dealt with them, is the subject of this Part.

Part II.A examines the ways in which ERA advocates characterized the Fourteenth Amendment's relationship to women's rights and feminists' prospects for success under existing constitutional provisions. Part II.B describes feminists' tenacious insistence on preserving their dual strategy in the face of what they saw as a threat-albeit inadvertent-from a sympathetic Senator's compromise ERA substitute. Part II.C and Part II.D discuss the dual strategy in practice, as feminists attempted to exploit its advantages and avoid its pitfalls. Both were on display in the Supreme Court's opinions in the first successful women's rights cases under the Equal Protection Clause, related in Part II.C. Part II.D explores the dilemmas of the dual strategy during the 1970s as feminists juggled litigation, legislation, and the quest for ERA ratification.

\section{A. "If Properly Interpreted": The Fourteenth Amendment in ERA Advocacy}

Choosing between constitutional paths was, in a certain sense, an old problem for advocates of constitutional change on behalf of women. Suffragists of the post-Civil-War era had faced a similar set of alternatives: they could, on the one hand, argue that the existing constitution mandated women's suffrage, or, on the other, that a new amendment was necessary to guarantee women's right to vote. ${ }^{218}$ But in Minor $v$.

218. For more on the suffragists' constitutional strategies, see Ellen Carol DuBois, Outgrowing the Compact of the Fathers: Equal Rights, Woman Suffrage, and the United States Constitution, 18201878, 74 J. AM. HIST. 836 (1987); Adam Winkler, A Revolution Too Soon: Woman Suffragists and the "Living Constitution," 76 N.Y.U. L. Rev. 1456 (2001); Rebecca A. Rix, Interpreting Women's "Privileges" After the Fourteenth Amendment: 1deas, Litigation, and Politics in the "New Departure," 1868-1875 (1999) (unpublished M.A.L.S. thesis, Reed College) (on file with the Reed College Library). 
Happersett (1874), ${ }^{219}$ the Supreme Court had "resolved" the suffragists" dilemma for them by denying that the Reconstruction Amendments embodied the principle of sex equality in voting privileges. In the early 1970 s, feminists had no such clear judicial signal to guide them. Hoyt $v$. Florida ${ }^{220}$ was almost a decade in the past, and lower courts had signaled some receptivity to the Fourteenth Amendment approach in cases like White $v$. Crook. ${ }^{221}$ Furthermore, after both the New Deal and civil rights revolutions had succeeded in winning constitutional change through judicial reinterpretation rather than textual amendment, the possibilities for a Court turnaround were more promising than in pre-New Deal eras. ${ }^{222}$

ERA proponents agreed that the Fourteenth Amendment, if "properly interpreted,"223 protected women from much of the discrimination the ERA was intended to eliminate. ${ }^{24}$ The dual strategy, however, created two related obstacles for them. First, they had to articulate to Congress the need for an ERA despite the supposed embodiment of sex equality principles in the Fourteenth Amendment. Second, they confronted the tactical problem that courts otherwise inclined to expand the reach of the Fourteenth Amendment might view feminists' promotion of an ERA as evidence that the existing constitution did not protect women's rights.

To address the first problem, ERA supporters invoked a range of reasons, both pragmatic and symbolic, why Congress should pass the amendment. Many emphasized that the prospects for the Fourteenth Amendment strategy were uncertain at best, hopeless at worst. Yale Law Professor Thomas Emerson called "a change by way of judicial interpretation" "not presently feasible," 225 while Pauli Murray declared in a written statement to the Senate that the PCSW's litigation strategy had "failed," proof that the

219. 88 U.S. (21 Wall.) 162 (1874).

220. 368 U.S. 57 (1961).

221. 251 F. Supp. 401, 408 (M.D. Ala. 1966).

222. Earlier efforts to win recognition of women's rights under the Constitution are described by Jules Lobel as "prophetic" or "aspirational." Jules Lobel, Losers, Fools \& Prophets: Justice as Struggle, 80 CoRnEll L. Rev. 1331 (1995).

223. Equal Rights 1970: Hearings on S.J. Res. 61 and S.J. Res. 231, Proposing an Amendment to the Constitution of the United States Relative to Equal Rights for Men and Women, Before the Senate Committee on the Judiciary, 91st Cong. 372 (1970) [hereinafter Equal Rights 1970] (statement of Caruthers Gholsen Berger on behalf of the NWP). Berger eontinued: "The [Fourteenth] amendment and [Fifth] amendment's guarantees extend to all persons." Id.

224. Even the NWP joined this consensus. See id. Rep. Martha Griffiths, a longtime ERA supporter, wrote to her Senate colleagues in 1970: "[A]ll supporters of [the ERA] agree that the Fourteenth Amendment, properly interpreted, would make the new Amendment redundant." 116 CoNG. REC. 36,863 (1970) (statement of Sen. Bayh (quoting Rep. Griffiths)).

225. Equal Rights for Men and Women 1971: Hearings on H.J. Res. 35, 208, and Related Bills, Proposing an Amendment to the Constitution of the United States Relative to Equal Rights for Men and Women, and H.R. 916 and Related Bills, Concerning the Recommendations of the Presidential Task Force on Women's Rights and Responsibilities, 92d Cong. 400 (1971) [hereinafter Equal Rights for Men and Women 1971] (statement of Prof. Thomas 1. Emerson). 
Court could not be trusted to put things right. ${ }^{226}$ ERA supporters also emphasized the time-consuming, expensive, piecemeal nature of litigation under existing constitutional provisions which, time and again, had been subject to unfavorable interpretations in the courts. "[W]hy should working women like myself have to spend thousands of dollars on litigation and wait years for a Federal Judge to make up his mind . . . [and] after all this still have to take cases to the Supreme Court[?]' Georgianna Sellers of the League of American Working Women demanded of the Senate Judiciary Committee in 1970. ${ }^{227}$ Talking points prepared for Rep. Don Edwards (D-CA) stressed the "immense practical difficulties of remedying the situation by piecemeal action," and cited the testimony of Professors Emerson, Leo Kanowitz, and Norman Dorsen to this effect. ${ }^{228}$ In her congressional testimony, Marguerite Rawalt recounted the long line of Supreme Court cases rendering the Fourteenth Amendment an ineffectual weapon against sex discrimination. ${ }^{229}$ And, while acknowledging that the Fourteenth Amendment picture was not entirely bleak, given scattered favorable lower court decisions, Emerson too invoked the "legal deadwood which must be cleared away before the courts will be prepared to make clear-cut and rapid progress." 230

Not all ERA proponents agreed with this gloomy forecast of the future of the Fourteenth Amendment strategy, but they nonetheless defended the need for an ERA. University of New Mexico Law Professor Leo Kanowitz, author of the 1969 book Women and the Law: The Unfinished Revolution, straightforwardly proclaimed his conviction that the Supreme Court would soon extend the Fourteenth Amendment's full protections to women. In September 1970, he told the Senate that he believed that "there is a very high degrce of probability that the United States Supreme Court, when it next confronts an equal protection or due process challenge to a sex discriminatory law, will drastically modify the undifferentiated principle" that allowed "reasonable" sex-based classifications. ${ }^{231}$ Kanowitz recognized the paradoxical nature of his support for an ERA notwithstanding the likelihood of judicial reinterpretation of existing constitutional provisions, but he had a justification at the ready: If the Court responded as he hoped and

226. Statement of Pauli Murray on the Equal Rights Amendment (S.J. Res. 61) Submitted to the Senate Judiciary Committee (Sept. 16, 1970) (Pauli Murray Papers, MC 412, Box 55, Folder 956, on file with the Schlesinger Library, Radcliffe Institute, Harvard University) [hereinafter Statement of Pauli Murray on the Equal Rights Amendment].

227. Id. at 286 (statement of Georgianna Sellers on behalf of the League for American Working Women).

228. Comments Prepared for Congressman Don Edwards on Statement of Professor Paul Freund on the Equal Rights Amendment (June 6, 1971) (Thomas Emerson Papers, 92-M-56, Box 26, Folder: ERA - Congress, on file with the Sterling Memorial Library, Yale University).

229. 116 CONG. REC. 19,349-52 (1970) (statement of Marguerite Rawalt).

230. Equal Rights 1970, supra note 223, at 307 (statement of Thomas 1. Emerson).

231. 116 CoNG. REC. 31,534 (1970) (statement of Leo Kanowitz). 
believed it would, "no harm will have been achieved by the presence of the Equal Rights Amendment"; if it did not, "then the need for the Equal Rights Amendment will have become manifest.,"232 Though less optimistic about the potential for judicial turnaround, Caruthers Gholsen Berger of the NWP agreed with Kanowitz's win-win scenario. Quoting Justice Joseph Story's Commentaries, she argued that there was "no reason why constitutional provisions may not overlap since "the securities of individual rights . . cannot be too frequently declared, nor in too many forms of words' in cases where a tendency has been shown by persons in high places to ignore such individual rights." ${ }^{233}$ In fact, Berger boldly asserted, "The advocates of equality of rights for women have a right to simultaneously press for the equal rights amendment and to fight in the court for the rights of women under the 14th amendment." 234 Indeed, feminists were doing exactly that: as Congress debated the ERA, the ACLU was helping to prepare the appeal in Reed $v$. Reed, ${ }^{235}$ which would reach the Suprome Court the following year.

Whether or not they forecasted success under the Fourteenth Amendment strategy, ERA supporters all emphasized the ERA's symbolic power as an emblem of women's legal equality with men. According to proponents across the political spectrum, an ERA had "great symbolic significance" and would "enhance the self-respect of women, in addition to the more tangible benefits," 236 would signal a "broad national commitment that the goal of equal status for women should be quickly and effectively achieved,"237 and would "help our country to become an example of the practical ideal that the sole purpose of governments is to create the conditions under which the uniqueness of each individual is cherished."238

Pauli Murray used a historical analogy to link the Fourteenth Amendment and the ERA. Both were necessary, she argued, to guarantee rights only ambiguously and uncertainly protected by existing constitutional provisions. "There were those members of Congress who were convinced that the Thirteenth Amendment adequately supported the full claims of the freed Negroes to citizenship and equal rights," Murray argued, but "[ $t]$ he uncertainty of Congressional authority under the Thirteenth Amendment... led to the adoption" of the Fourteenth

232. Id.

233. Equal Rights 1970, supra note 223, at 373 (statement of Caruthers Gholsen Berger on behalf of the NWP) (alteration in original).

234. Id. at 372 .

234. 465 P.2d 635 (Utah 1970).

236. 116 Cong. REC. 29,997 (statement of Sen. Cook).

237. Testimony of Thomas I. Emerson Before Sub-Committee No. 4 of the House Judiciary Committee on the Equal Rights Amendment and H.R. 916 and H.R. 4589 (Mar. 1971) (Thomas Emerson Papers, 92-M-56, Box 26, Folder: ERA-Congress, on file with the Sterling Memorial Library, Yale University).

238. Statement of Pauli Murray on the Equal Rights Amendment, supra note 226, at 18. 
Amendment's Equal Protection Clause. ${ }^{239}$ Similarly, she argued, the uncertainty produced by uneven and mostly discouraging judicial decisions warranted an unambiguous constitutional declaration of women's rights. ${ }^{240}$ First and foremost, though, Murray emphasized the substantive and symbolic consequences of the ERA for the group historically most subjugated by discrimination-African-American women. "[T]he Negro woman," Murray told the Senate, "has suffered more than the mere addition of sex discrimination to race discrimination. She has suffered the conjunction of these twin immoralities which produced an aggravated condition of degraded status from which she has not yet recovered."241

Although ERA advocates marshaled a variety of rationales in support of the Amendment, arguments about the relative legitimacy of formal amendment versus judicial reinterpretation surfaced only occasionally, mostly in the pro-ERA testimony of law professors. One devotee of legal process did speak in favor of the democratic virtues of constitutional change through formal amendment. Robert Braucher of Harvard Law School, a Republican who testified for the ERA on behalf of the Unitarian Universalist

Association, told Congress that

[j]udicial reform of obsolete laws under the banner of "equal protection of the laws" is likely to savor of usurpation when the obsolete law is hallowed by widespread acceptance over a long period of time [whereas] ... [a] Constitutional Amendment gives the judges a mandate to which they can respond with confidence that they are in step with the democratic process. ${ }^{242}$

Other arguments about the virtues of formal amendment were solely instrumental. Emerson, himself uninhibited by concerns about judicial overreaching, invoked the specter of democratic illegitimacy as a reason why judges were unlikely to reinterpret the Fourteenth Amendment to equalitarians' satisfaction. "[T]he Supreme Court has been subjected ... to powerful attack for moving too fast and too far into frontier areas of the law," he noted. ${ }^{243}$ "The Court may consequently be somewhat reluctant to take the lead in bringing about another major social reform, regardless of how constitutionally justified that reform may appear to be." "244 In another submission to Congress, Emerson remarked slyly that "[t]hose who complain that the Supreme Court has been exceeding its powers through

\footnotetext{
239. Id. at 13 .

240. Id. at 13-14.

241. Id. at 5; see also HARTMANN, supra note 25, at 205 (discussing Murray's ERA testimony).

242. Statement of Robert Braucher on behalf of the Unitarian Universalist Association in Support of the Equal Rights Amendment 3 (Sept. 4, 1970) (Pauli Murray Papers, MC 412, Box 123, Folder 2206, on file with the Schlesinger Library, Radcliffe Institute, Harvard University).

242. Equal Rights 1970, supra note 223, at 301 (statement of Thomas I. Emerson).

244. Id.
} 
interpretation of constitutional provisions should especially welcome the amending process." 245 To Emerson and many of his feminist allies, the relative legitimacy of formal textual amendment versus judicial reinterpretation of existing provisions was relevant only in the context of a political climate that placed a premium on formal constitutional processes and scorned judicial activism.

In sum, proponents of the ERA invoked judicial intransigence, the unjust expenditure of resources on litigation, the symbolic significance of a textual amendment, and in Murray's case, the need to fulfill the Fourteenth Amendment's promise by affording African-American women genuine protection from discrimination. When they occasionally mentioned democratic legitimacy as a justification for preferring textual amendment, it was usually as an instrumental benefit, given the contemporary climate of judicial conservatism. Moreover, it was nearly always law professors who raised the legitimacy issue, and even then, for adherents of the dual constitutional strategy, pragmatism was the prevailing determinant of constitutional path.

While many, if not all, ERA proponents offered explanations for the need to amend the constitutional text despite the Fourteenth Amendment's concurrent coverage, few faced head-on the second conundrum-signaling to the courts that the ERA's passage should not be viewed as a barrier to favorable interpretation of existing constitutional provisions. Professor Kanowitz did address this dilemma, emphasizing in his testimony that Congress must "make sure that the record disclose[d]" that the legislature did not "intend to discourage" the Supreme Court from interpreting the Equal Protection Clause "so as to eliminate every sex-based discrimination in American law." 246 There was, Kanowitz recognized, "a very real danger that if this is not done, the adoption of the Amendment at this time will ultimately represent a defeat rather than a victory," for the Court was likely to reason that if Congress "deemed it neeessary to adopt the Equal Rights Amendment, then it must have believed that existing constitutional provisions were inadequate to provide the needed relief." 247

This strategic concern did not fully surface until Birch Bayh, a member of the Judiciary Committee and the primary Senate sponsor of the ERA, launched a last-ditch effort to push the Amendment through before Congress adjourned its 1970 session. As the legislators were preparing to leave for their fall recess, Bayh introduced an amendment in the form of a substitute to the original ERA legislation, essentially extending the language of the Fourteenth Amendment's Equal Protection Clause explicitly

\footnotetext{
245. Equal Rights for Men and Women 1971, supra note 225, at 400 (statement of Thomas I. Emerson).

246. I 16 CoNG. ReC. 31,354 (1970) (statement of Leo Kanowitz)

247. Id.
} 
to cover discrimination based on sex. The introduction of the Bayh substitute occasioned a more sustained feminist articulation of the relationship between the Fourteenth Amendment, the ERA, and the constitutional change legal feminists sought.

\section{B. "New Language Is Required": The Rise and Fall of the Bayh Substitute}

As the ERA stalled in the Senate in September 1970, crippled by a killer school prayer amendment, Senator Birch Bayh sought a compromise that he hoped would placate both proponents and opponents of the ERA. The ERA's foes had argued that the amendment would have a variety of undesirable consequences, some of which seemed to Bayh and several of his colleagues as if they might be curable through revisions to the amendment's language. For instance, University of Chicago Law Professor Philip Kurland worried that the ERA's ambiguous meaning would lead to unintended consequences and excessive litigation. ${ }^{248}$ Harvard Law Professor Paul Freund, a prominent ERA opponent since the 1940s, also expressed concern that the ERA would result in "chaos" at all levels of government, as courts, legislatures, and administrative bodies struggled to determine its impact on long-standing statutes and regulations. ${ }^{249}$ Freund invoked a parade of horribles the ERA might produce, including the legalization of same-sex marriage, the abolition of husbands' duty of familial support, unisex bathrooms, and women in military combat. ${ }^{250}$ In doing so, he emphasized the amendment's inflexibility, its mandate of absolute equality that would brook no distinctions based on scx, no matter how firmly rooted in law, custom, or Freund's conception of common sense. ${ }^{251}$

To be sure, changes in wording could not satisfy those ERA opponents who, like Senator Sam Ervin of North Carolina, essentially sought to maintain of traditional sex roles. ${ }^{252}$ But Bayh and an ideologically diversc group of his colleagues offered a compromise solution. ${ }^{253}$ The Bayh substitute essentially rccapitulated the language of the Fourteenth Amendment's

248. Equal Rights 1970, supra note 223, at 87-103 (statement of Philip B. Kurland).

249. Id. at 82 (statement of Paul A. Freund).

249. Id. at $72-86$.

251. Id.

252. For an insightful discussion of Ervin's opposition to the ERA, see MATHEWS \& DE HART, supra note 175 , at $28-53$.

253. Supporters of the Bayh substitute included some longtime ERA proponents and others who professed allegiance to the cause of equality but had in the past objeeted to the ERA as a means of attaining it. Senators Jacob Javits (R-NY), Robert Dole (R-KS), Edward M. Kennedy (D-MA), and Marlow Cook (R-KY) numbered among those favoring the substitute. The substitute read as follows:

SECTION 1. Neither the United States nor any State shall, on account of sex, deny to any person within its jurisdiction the equal protection of the laws.

SEC. 2 . The Congress shall have power to enforce, by appropriate legislation, the provisions of this article.

SEC. 3. This article shall take effect two years after the date of ratification.

H.R.J. Res. 264, 91 st Cong. (2d Sess. 1970). 
Equal Protection Clause but explicitly applied the provision to discrimination based on sex. This new version was, in Bayh's own words, "designed to provide most of the affirmative benefits which are sought by its sponsors, while meeting the objections of its most articulate critics."254 The senators who had supported the ERA, Bayh contended, "had done so because we believe that the 14th amendment guarantee of equal protection of the law must be extended to cases involving discrimination on account of sex."255 Further, Bayh considered the most persuasive opposing arguments to have been made by Freund and others who worried about the ERA's lack of flexibility. Declaring that he and many of his colleagues had always viewed the ERA as a flexible tool whose equality mandate would give way to "overriding and compelling public interest," Bayh proposed that this flexibility be memorialized in an amendment that echoed the more malleable Fourteenth. ${ }^{256}$

Bayh claimed his substitute amendment would have three benefits. First, he argued, his version would "make it absolutely clear that the Congress and the country do not agree with the implication of the Supreme Court's decisions in this area." ${ }^{257}$ Second, the substitute would eliminate "most, if not all of the few serious remaining statutory discriminations that would have been eliminated by the equal rights amendment," and would retain the ERA's "most essential benefit ... the extraordinary symbolic value of a national mandate in the area of discrimination on account of sex." ${ }^{258}$ Finally, Bayh contended, the substitute "would clearly prevent the kind of restrictive interpretation which the critics have feared," because its recapitulation of the Fourteenth Amendment's language "would incorporate a vast body of history and judicial precedent," thereby ensuring "continuity and consistency."259 According to Bayh, Fourteenth Amendment jurisprudence constituted "a coherent and comprehensive body of law" that would surely be easily transferable to the sex discrimination context. ${ }^{260}$

The response from women's organizations to the Bayh substitute was swift and scathing. Simply applying the Equal Protection Clause to sex discrimination would hardly ameliorate the ambiguities Bayh wished to address, feminists argued, since the Fourteenth Amendment was itself the very source of the judicial uncertainty and inconsistency the ERA was

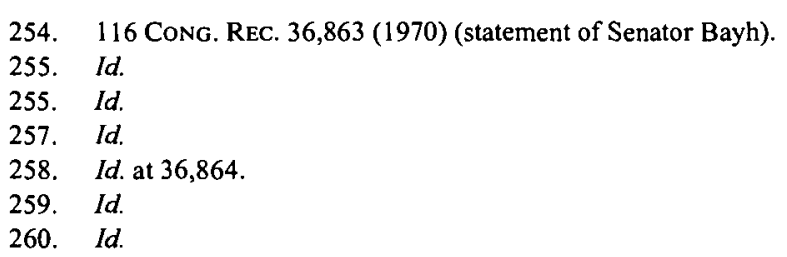


meant to obliterate. ${ }^{261}$ The substitute "seems nice enough in appearance," but "is admittedly intended not to guarantee equality under the law for women, but to implement and carry out what the opponents of the Equal Rights Amendment want," complained one widely-circulated critique. ${ }^{262}$ "We want an amendment that is meaningful, not a watered down and incomplete version of an existing constitutional amendment." ${ }^{263}$ To add insult to injury, the initial Bayh proposal included only the Fourteenth Amendment's Equal Protection Clause, omitting the due process and privileges or immunities guarantees. ${ }^{264}$

Taken somewhat aback by the vehemence of feminist opposition, Bayh attempted to salvage his substitute by issuing a revised proposal that included the previously omitted clauses. ${ }^{265}$ Moreover, in response to concerns that the judiciary would continue to apply a reasonableness standard to sex-based distinctions, he also assured feminist skeptics that the legislative history of his substitute would make crystal clear to judges that its effect was to require strict scrutiny. ${ }^{266}$ Feminists remained unconvinced, however. Their deep distrust of judicial proclivities could not so breezily be put aside. If the Court were confused about the appropriate standard of

261. See, e.g., Letter from Aileen Hernandez to Sen. Birch Bayh (Oct. 30, 1970) (Thomas Emerson Papers, 92-M-56, Box 25, Folder: ERA-Congress 1970, on file with the Sterling Memorial Library, Yale University); Letter from Alan Reitman to Dorothy Kenyon (Oct. 23, 1970) (Dorothy Kenyon Papers, Box 29, Folder 1, on file with the Sophia Smith Collection, Smith College) ("It was precisely the failure of the Supreme Court to apply the equal protection clause to women which made us turn to the Equal Rights Amendment as the technique for achieving our policy position."); Memorandum from Marguerite Rawalt, Re: Status of the Equal Rights Amendment (Nov. 27, 1970) (Pauli Murray Papers, MC 412, Box 95, Folder 1674, on file with the Schlesinger Library, Radcliffe Institute, Harvard University) ("[The substitute] is unacceptable to proponents [of the ERA] because it declared that the substitute language of the equal protection clause would 'incorporate a vast body of history and judicial precedent'-while the existing judicial precedents specifically that 'sex is a valid classification' for denying equality to women, are precisely [w] hat proponents seek to eradicate, not to incorporate").

262. Why the Bayh/Kennedy Substitute to the Equal Rights Amendment is Not Satisfactory to Women 3-4 (Oct. 15, 1970) (Mary Eastwood Papers, 83-M257, Carton 3, Folder 12, on file with the Schlesinger Library, Radcliffe Institute, Harvard University).

263. Id. at 3 .

264. See, e.g., Letter from Dorothy Kenyon to Alan Reitman (Nov. 2, 1970) (Dorothy Kenyon Papers, Box 29, Folder 1, on file with the Sophia Smith Collection, Smith College); Letter from Dr. Bernice Sandler, Women's Equity Action League, to Sen. Birch Bayh (Oct. 25, 1970) (Mary Eastwood Papers, 83-M257, Carton 3, Folder 1, on file with the Schlesinger Library, Radcliffe Institute, Harvard University) [hereinafter Letter from Sandler to Bayh] ("The proposed substitute... implies that the remainder of the 14 th - the due process clause, and the privileges and immunities clause-does not apply to women.").

265. See, e.g., Letter from Sen. Birch Bayh to Bernice Sandler (Oct. 29, 1970) (Pauli Murray Papers, MC 412, Box 95, Folder 1675, on file with the Schlesinger Library, Radcliffe Institute, Harvard University) [hereinafter Letter from Bayh to Sandler].

266. Id. 
review or how to apply it, bad decisions might result. ${ }^{267}$ Moreover, even if the compelling state interest test were clearly applicable, the Court's history of sanctioning sex discrimination might lead judges to determine that the old protectionist justifications did in fact serve such interests. ${ }^{268}$ "The words 'equal protection' have already acquired meanings as applied to women which perpetuate irrelevant distinctions and open the door to discrimination," Murray wrote to Bayh. ${ }^{269}$ "To make a break with these past meanings, new language is required." 270

ERA proponents were also concerned about the signal that passage of a substitute would send to courts. Emerson, for instance, argued that the fact that a substitute was necessary at all would lead courts to believe that it was not intended to have the same practical effect as the ERA, while at the same time giving the judiciary no interpretive guidance. ${ }^{271}$ Feminists also worried about the Bayh substitute's potential effect on the other prong of their dual strategy-litigation under the Fourteenth Amendment. Reliance on the Fourteenth Amendment's language would, they feared, effectively freeze existing judicial interpretation of that amendment rather than opening the way for more expansive readings of its provisions. ACLU attorney Marvin Karpatkin wrote to Bayh that he feared "the combination of ambiguous language and an ambiguous legislative history will not only fail to break down discriminations which have been condoned under the Fourteenth Amendment in the past but will actually make those discriminations virtually permanent by elevating them to a constitutional status."272 Further, the passage of an amendment recapitulating the Fourteenth would imply that the existing Constitution did not cover sex discrimination at all. If the substitute were not immediately ratified-or, even worse, "if the substitute were passed by Congress but not ratified, this would freeze into being that the [Fourteenth Amendment] does not apply to women at all,"273 wrote Bernice Sandler of the Women's Equity Action League to Bayh.

267. See, e.g., Letter from Ann Corinne Hill, Yale Law Women's Association, to Sen. Birch Bayh (Nov. 6, 1970) (Thomas Emerson Papers, 92-M-56, Box 25, Folder: ERA-Congress 1970, on file with the Sterling Memorial Library, Yale University).

268. Id. at 1-2; Letter from Thomas Emerson to Sen. Birch Bayh 2 (Nov. 6, 1970) (Thomas Emerson Papers, 92-M-56, Box 25, Folder: ERA-Congress 1970, on file with the Sterling Memorial Library, Yale University) [hereinafter Letter from Emerson to Bayh].

269. Letter from Pauli Murray to Sens. Birch Bayh and Marlow W. Cook 2 (Nov. 8, 1970) (Pauli Murray Papers, MC 412, Box 95, Folder 1674, on file with the Schlesinger Library, Radcliffe Institute, Harvard University).

270. Id. Nor would reliance on legislative history provide sufficient clarification of the substitute's meaning, ERA proponents argued. E.g., Letter from Marvin Karpatkin, ACLU, to Sen. Birch Bayh 2 (Nov. 25, 1970) (Thomas Emerson Papers, 92-M-56, Box 25, Folder: ERA-Congress 1970, on file with the Sterling Memorial Library, Yale University) [hereinafter Letter from Karpatkin to Bayh].

271. Letter from Emerson to Bayh, supra note 268, at 2.

272. Letter from Karpatkin to Bayh, supra note 270 , at 2.

273. Letter from Sandler to Bayh, supra note 264, at 2. 
Bayh protested that his substitute would do no such thing. In fact, he contended, the Supreme Court would be even more likely to apply suspect classification analysis under the Fourteenth Amendment if Congress passed his measure. "Indeed," he wrote to Sandler, "the Court would often prefer to rely on some demonstrated government action, as a reflection of the more fundamental changes in society, in deciding to apply a stricter standard of review."274 Despite their appreciation for Bayh's good-faith effort, women's groups were unmoved by these assurances. On November 11, 1970, feminist organizations issued a joint statement expressing their unanimous opposition to the Bayh substitute. ${ }^{275}$ Less than two years earlier, Mary Eastwood had observed that "the division in the movement seems to be so severe" that she doubted "if the various feminist organizations could work together on anything." 276 Now she wrote triumphantly to Murray: "I think we have pretty much permanently finished off Bayh's substitute .... The women's movement really came through fine on this issue." 277

The defeat of Birch Bayh's substitute in the autumn of 1970 demonstrated both the newfound unity of the women's movement and legal feminists' strong commitment to the dual constitutional strategy. The Bayh substitute was unsatisfactory because feminists perceived it - and feared that courts would view it - as a compromise designed to placate critics of the ERA. But it also posed a danger to the second prong of feminist constitutional strategy, the continued litigation efforts under the Fourteenth Amendment. Were the Bayh substitute to succeed, interpretations of the Fourteenth Amendment might be frozen in constitutional time, reifying archaic notions of equal protection rather than expanding the concept of equal rights to include women and suggesting that the Fourteenth Amendment did not encompass women's rights at all. In short, the Bayh substitute compromised the dual strategy from every angle, and in the new era of feminist unity, it was doomed to defeat from the start. ${ }^{278}$

Vanquishing the Bayh substitute did not mean conquering the dilemmas of the dual strategy, however. In fact, the next section demonstrates

274. Letter from Bayh to Sandler, supra note 265, at 2.

275. Eileen Shanahan, Women's Rights Amendment Appears Dead for 1970, N.Y. TIMEs, Nov. 12, 1970 , at 19.

276. Letter from Mary Eastwood to Pauli Murray (Jan. 13, 1969) (Pauli Murray Papers, MC 412, Box 95, Folder 1657, on file with the Schlesinger Library, Radcliffe Institute, Harvard University).

277. Letter from Mary Eastwood to Pauli Murray (Nov. 15, 1970) (Pauli Murray Papers, MC 412 , Box 95, Folder 1657, on file with the Schlesinger Library, Radcliffe Institute, Harvard Univcrsity) (adding that "a 'compromise' version just to win something was so tempting to the less sophisticated ....") (emphasis added).

278. Mary Frances Bcrry suggests that the Bayh substitute also "would have created an opportunity for antagonists to weaken the protection against race discrimination, which no civil rights proponent cared to do." Mary Frances Berty, Book Review, 96 AM. Hist. Rev. 997, 998 (1991) (reviewing Graham, supra note 90, and responding to Graham's puzzlement that feminists did not accept the compromise). 
that as women's rights cases made their way to the Supreme Court for the first time just as the ERA reached a peak of national attention and support, the double-edged nature of the dual approach was thrown into sharp relief.

\section{C. "We Have Taken a Baby Step": The Dual Strategy in the Supreme Court}

When a new Congress convened in 1971, the ERA was once again before the House, which heard more testimony from many of the same witnesses who spoke during the previous session. A new facc also appeared before the legislators - that of Assistant Attorney General William H. Rehnquist, presenting the DOJ's assessment of the ERA. Privately, Rehnquist had expressed his view that the ERA's “overall implication" was "nothing less than the sharp reduction in importance of the family unit, with the eventual elimination of that unit by no means improbable."279 In an internal administration memorandum, Rehnquist responded to a brief for the ERA prepared for the CACSW by Mary Eastwood, ${ }^{280}$ then his subordinate in the DOJ. Rehnquist's memo warned of the ERA's possibly dire consequences-consequences that threatened to transform "holy wedlock" into "holy deadlock."281 Nearly all invidious discriminations against women had already been eliminated, Rehnquist argued; the ERA would merely eliminate the legal protections women had long enjoyed. ${ }^{282}$ He opined that while " $[u]$ ndoubtedly many of the supporters of the equal rights for women amendment have rationally and carefully considered these questions," he could "[]not help thinking that there is also present somewhere in this movement a virtually fanatical desire to obscure not only legal differentiation between men and women, but insofar as possible, physical distinctions between the sexes." ${ }^{283}$ In feminism, Rehnquist saw "overtones of dislike and distaste for the traditional difference between men and women in the family unit, and in some cases very probably a complete rejection of women's traditionally different role in this regard."284

279. Memorandum from William H. Rehnquist, Assistant Attorney General, Office of Legal Counsel, DOJ, to Leonard Garment, Special Counsel to the President (1970), reprinted in LEgAL Times, Sept. 15, 1986, at 4, 5 [hereinafter Memorandum from Rehnquist to Garment]. Rehnquist's memo detailing arguments against the ERA was exhumed by opponents of his nomination to become Chief Justice of the Supreme Court in 1986.

280. Eastwood prepared her memorandum with Rehnquist's permission. Letter from Jacqueline Gutwillig, Chairman, CACSW, to William Rehnquist (Jan. 14, 1970) (Mary Eastwood Papers, 83M257, Carton 1, Folder 6, on file with the Schlesinger Library, Radcliffe Institute, Harvard University) (requesting Eastwood's participation, with handwritten note from "Bill R." to "Mary" granting permission).

281. Memorandum from Rehnquist to Garment, supra note 279, at 4.

281. Id.

283. Id.

284. $I d$. 
The administration, Rehnquist wrote, should not "support a change which will in fact hasten the dissolution of the family."285

In his statements to Congress, Rehnquist voiced additional hesitations about the ERA. Nominally, the DOJ supported the amendment, but overall, feminists viewed Rehnquist's testimony as, at best, damning with faint praise. There was "no denying," Rehnquist testified, "that opponents of th[e] amendment have raised significant questions which deserve the serious consideration of the [House Judiciary C]ommittee."286 He warned that the "broad general language" of the ERA would "add substantial uncertainties in this area of constitutional law which would probably require extensive and protracted litigation to dispel."287 Furthermore, Rehnquist argued, the Supreme Court was soon likely to move in a liberalizing direction with respect to sex discrimination claims under the Fourteenth Amendment. ${ }^{288}$

Rehnquist testified in April 1971. In October, the House passed the ERA, stripped of all qualifying exceptions and amendments, by the wide margin of 354 to 23 . Nine days later, President Nixon nominated Rehnquist to fill Justice John Marshall Harlan's seat on the United States Supreme Court. Just one month later in Reed v. Reed, the Court, for the first time ever, invoked the Fourteenth Amendment's equal protection guarantee to unanimously strike down a law discriminating against women-a recently repealed Idaho statute preferring male estate administrators to females. ${ }^{289}$

Reed was a state court case plucked out of obscurity by feminists who sought Supreme Court resolution of the proper standard of review for sexdiscriminatory laws under the Fourteenth Amendment. ACLU Legal Director Melvin Wulf enlisted the help of Ruth Bader Ginsburg, law professor and budding women's rights expert, to draft the appellant's brief to the Supreme Court. ${ }^{290}$ In that brief, Ginsburg and her colleagues built upon the previous work of Pauli Murray and Dorothy Kenyon (both of whom were credited as the brief's coauthors) to argue not only that the distinction between male and female estate administrators that had favored Sally Reed's husband at her expense was unreasonable, but also that all

285. Id. at 5 .

286. Equal Rights for Men and Women 1971, supra note 225, at 312 (statement of William $\mathrm{H}$. Rehnquist).

287. Id.

288. Id.

289. 404 U.S. 71,77 (1971). Rehnquist was not sworn in until January 1972, and so did not participate in the Reed decision.

290. See, e.g., Letter from Ruth Bader Ginsburg to Melvin Wulf (Mar. 2, 1971) (ACLU Records, Box 1645, Folder: Reed v. Reed, on file with the Mudd Manuscript Library, Princeton University) (requesting information about the case); Letter from Mclvin Wulf to Ruth Bader Ginsburg (Mar. 9, 1971) (ACLU Records, Box 1645, Folder: Reed v. Reed, on file with the Mudd Manuscript Library, Princeton University) [hereinafter Letter from Wulf to Ginsburg] (requesting Ginsburg's assistance). 
sex-based legal distinctions were, like race-based distinctions, inherently suspect. $^{291}$

The ACLU attorneys saw Reed as a golden opportunity to impress upon the Court the inherent injustice of sex-based legal classifications. Wulf was particularly adamant that Reed's significance went far beyond Idaho's refusal to consider Sally Reed and her husband as equally capable of administering their deceased son's small estate. He browbeat amici who did not prioritize the argument for strict scrutiny of sex-based classifications over the contention that this particular classification was unreasonable enough to fail even rational basis review. ${ }^{292}$ Wulf also attempted, unsuccessfully, to wrest the case away from Allen Derr, Sally Reed's personal attorney, and to draft former ACLU attorney Eleanor Holmes Norton to argue the case before the Supreme Court. ${ }^{293}$ The ACLU had devoted considerable resources to writing the widely praised brief for Mrs. Reed, which, as the "grandmother brief," would serve as a template for future Supreme Court submissions in sex discrimination cases. Wulf shuddered at the possibility that someone he perceived as an inexperienced lawyer with little knowledge of the constitutional issues at stake would boteh the oral presentation of Reed to the Court.

291. Brief for Appellant, Reed v. Reed, 404 U.S 71 (1971) (No. 70-4).

292. Wulf wrote one amici:

Our brief argued firstly and predominantly that sex should be denominated as 'suspect.' Our second point is that the classification is irrational. Your brief reverses those positions. Thus, to the extent that your brief will have any influence at all with the Court, it will injure our position. Such favors 1 don't need.

Letter from Melvin Wulf to Norman Redlich, Office of Corporation Counsel 1 (July 1, 1971) (ACLU Records, Box 1645, Folder: Reed v. Reed, on file with the Mudd Manuscript Library, Princeton University).

293. Wulf attempted to persuade Derr that because of the inability of the plaintiffs' male attorney in a recent employment discrimination case, Phillips v. Martin Marietta Corp., 400 U.S. 542 (1971), to fend off the "locker-room humor" of the justices, and because of the symbolic value of having a female attorney argue the first constitutional sex discrimination case to reach the Court in a decade, Derr should allow a woman to argue Reed. Wulf also attempted to enlist the help of longtime feminists such as Rep. Martha Griffiths and NOW president Wilma Scott Heide to convince Sally Reed to authorize a more experienced attorney to handle the oral argument. Derr declined to respond to Wulf's increasingly insistent letters until it was too late to ask the Court to allow a split argument. See Letter from Wulf to Ginsburg, supra note 290 (announcing intention to "fight off my co-counsel in 1daho"); Letter from Melvin L. Wulf to Allen R. Derr (June 4, 1971) (ACLU Records, Box 1645, Folder: Reed v. Reed, on file with the Mudd Manuscript Library, Princeton University) (suggesting that for both symbolic and pragmatic reasons, the Reed case should be argued by a woman); Letter from Melvin L. Wulf to Allen R. Derr (Oct. 8, 1971) (ACLU Records, Box 1645, Folder: Reed v. Reed, on file with the Mudd Manuscript Library, Princeton University) (excoriating Derr for allowing his "ego satisfaction" to get in the way of a competent Supreme Court argument in Reed); Letter from Melvin L. Wulf to Allen R. Derr (Dec. 20, 1971) (ACLU Records, Box 1645, Folder: Reed v. Reed, on file with the Mudd Manuscript Library, Princeton University) (blaming Derr for the Court's "bland and very narrow opinion"); Telegram from Allen R. Derr to Melvin L. Wulf (Dec. 26, 1971) (ACLU Records, Box 1645, Folder: Reed v. Reed, on file with the Mudd Manuscript Library, Princeton University) ("My client and I are sorry we allowed your help in the case of Reed versus Reed."). 
At oral argument, Wulf's fears were realized. He wrote to Derr that the Idaho lawyer's performance "fulfilled my worst expectations. The argument," Wulf declared, "may have been one of the worst in the history of the Supreme Court." 294 He nevertheless predicted victory, which came in November in a unanimous, but rather cryptic, ruling authored by Chief Justice Warren E. Burger. The Court declared Idaho's preference for male estate administrators to be "arbitrary," but did not disturb the "reasonableness" standard for evaluating sex-based classifications under the equal protection clause. ${ }^{295}$ Wulf blamed Derr's inexpert argument for the Court's "bland and very narrow opinion," $" 96$ and emphasized to the national press that the Court had not fulfilled his hopes for a broader, more expansive decision. ${ }^{297}$

Many feminists agreed that Reed was less than a clear-cut victory. Having remarked several months earlier that she would "resign from the human race" if Mrs. Reed lost her case, ${ }^{298}$ Rep. Martha Griffiths now predicted that the Court would remain a "'bottleneck' for women's rights."299 Senator Sam Ervin seized on the decision as proof that an ERA was unnecessary, ${ }^{300}$ but feminists heartily disagreed. In fact, they argued, the very narrowness and vagueness of the Reed decision made the need for an ERA all the more stark. Women's Bureau director Elizabeth Duncan Koontz noted that "analysis of the decision indicates that the need for a constitutional amendment is as compelling as ever." 301 A Washington Post editorial agreed, asserting that Reed was decided "on the narrowest possible grounds," and did not "in any way diminish the need for the constitutional amendment." $" 302$

Pauli Murray expressed her persistent qualms about the likelihood of a judicial overhaul of sex discrimination jurisprudence to Mary Dublin Keyserling, one of the few remaining protectionist holdouts from the I960s Women's Bureau coalition. In December, Murray wrote Keyserling of her disappointment at the Court's failure to accept the suspect classification

294. Letter from Mclvin L. Wulf to Allen R. Derr (Oct. 21, 1971) (ACLU Records, Box 1645,

Folder: Reed v. Reed, on file with the Mudd Manuscript Library, Princeton University).

294. Reed, 404 U.S. at 77.

296. Letter from Melvin L. Wulf to Allen R. Derr (Dec. 20, 1971) (ACLU Records, Box 1645,

Folder: Reed v. Reed, on file with the Mudd Manuscript Library, Princeton University).

297. Court Rules Out Bias By Legislators, Associated Press, Nov. 23, 1971 (ACLU Records, Box 1646, Folder: Reed v. Reed, on file with the Mudd Manuscript Library, Princeton University) (quoting Wulf's statement that he was "moderately pleased that we won the case, but the pleasure is very qualified because we did not win on the broader grounds").

298. Letter from Rep. Martha Griffiths to Melvin L. Wulf (July 6, 1971) (ACLU Records, Box 1645 , on file with the Mudd Manuscript Library, Princeton University).

299. See GraHaM, supra note 90 , at 418.

300. Court Rules Out Bias By Legislators, supra note 297 (quoting Sen. Sam Ervin).

301. Letter from Elizabeth Duncan Koontz, Women's Bureau, Department of Labor (Dec. 1971) (ACLU Records, Box 1146, Folder 6, on file with the Mudd Manuscript Library, Princeton University).

302. Editorial, Sex and the Single Administratrix, WASH. Post, Nov. 29, 1971, at A20. 
argument, and emphasized that the Reed decision had deepened her conviction that an ERA was not "less preferable than a case-by-case approach." Murray was hopeful that "[t]he pressure for ERA may force the Court to take the additional steps," but "what with a possible Renquist [sic] on the Court ... I shudder to think what the Court might do. Anyway, we have taken a baby step." 304

In March 1972, the Senate approved the ERA and sent it to the states for consideration. Ten months later, Ruth Bader Ginsburg argued the second major women's rights case of the decade, Frontiero v. Richardson, ${ }^{305}$ before the Supreme Court, in her capacity as head of the newly created ACLU Women's Rights Project (WRP). ${ }^{306}$ The advantages and pitfalls of the dual strategy were on display in the Court's opinions, issued in May. For Justice Brennan, who wrote a plurality opinion endorsing strict scrutiny for sex-based classifications, congressional passage of the ERA weighed in support of judicial reinterpretation of the Fourteenth Amendment. The ERA's passage indicated to him that "Congress itself has concluded that classifications based upon sex are inherently invidious." 307 Brennan opined that "this conclusion of a coequal branch of Government is not without significance to the question presently under consideration." 308

Brennan's assessment would have become law had one more Justice joined the plurality. Instead, Justice Stewart concurred in the plurality's judgment only, while Justice Powell wrote a concurrence, joined by Burger and Blackmun, arguing that the ERA's pendency militated against, rather than in favor of, a more expansive interpretation of the Equal Protection Clause. Powell deemed the ratification process a "compelling ... reason for deferring a general categorizing of sex classifications as invoking the strictest test of judicial scrutiny. ${ }^{, 309}$ He continued:

By acting prematurely and unnecessarily, as I view it, the Court has assumed a decisional responsibility at the very time when state

303. Letter from Pauli Murray to Mary Dublin Keyserling 1 (Dec. 7, 1971) (Pauli Murray Papers, MC 412, Box 95, Folder 1657, on file with the Schlesinger Library, Radcliffe Institute, Harvard University).

304. Id. at 1-2.

305. 411 U.S. 677 (1973).

306. The WRP was officially created in March 1972. HARTMANN, supra note 25, at 82. For more on the early years of the WRP, see Ruth B. Cowan, Women's Rights Through Litigation: An Examination of the American Civil Liberties Union Women's Rights Project, 1971-1976, 8 CoLum. Hum. RTs. L. REv. 373 (1976).

307. Frontiero, 411 U.S. at 687.

308. Id. at 687-88. Mark Tushnet views Brennan's articulation of the ERA's relevance in Frontiero as a quintessential example of his "majoritarian egalitarianism." Mark Tushnet, Justice Brennan, Equality, and Majority Rule, 139 U. PA. L. REv. 1357, 1357, 1361 -62 (1991). For more on the influence of congressional determinations on judicial interpretations of constitutional provisions, see Post \& Siegel, Legislative Consitutionalism, supra note 5; Post \& Siegel, Equal Protection by Law, supra note 5.

309. Frontiero, 411 U.S. at 692 (Powell, J., concurring in the judgment). 
legislatures, functioning within the traditional democratic process, are debating the proposed [Equal Rights] Amendment. It seems to me that this reaching out to pre-empt by judicial action a major political decision which is currently in process of resolution does not reflect appropriate respect for duly prescribed legislative processes. ${ }^{310}$

In a memorandum to Brennan, Justice Blackmun made a similar argument: "It seems to me that Reed $v$. Reed is ample precedent here and is all we need and that we should not, by this case, enter the arena of the proposed Equal Rights Amendment."311

Brennan valiantly attempted to dissuade his colleagues from this position and win their adherence to his pathbreaking opinion. He gave two primary reasons for disagreeing with Powell's assessment. First, he cited Justice Marshall's dissent in the recent San Antonio v. Rodriguez decision, which had persuaded Brennan that the only coherent rationale for Reed involved the designation of sex as a suspect classification. ${ }^{312}$ Second, Brennan observed, the Court could "[n]ot count on the Equal Rights Amendment to make the equal protection issue go away." 313 Presciently, he predicted it was unlikely that a sufficient number of states would ratify the Amendment, but he argued that "whether or not the Equal Rights Amendment eventually is ratified, we cannot ignore the fact that Congress and the legislatures of more than half the States have already determined that classifications based upon sex are inherently suspect." 314 Regardless of whether ERA enjoyed enough support to become part of the Constitution, Brennan suggested, its successes to date warranted the Court's reinterpretation of the Fourteenth Amendment.

310. Id. Powell wrote the following in a memorandum to Brennan explaining why he could not join Brennan's opinion:

My principal concem about going this far at this time, as indicated in my earlier letter, is that it places the Court in the position of preempting the amendatory process initiated by the Congress. If the Equal Rights Amendment is duly adopted, it will represent the will of the people accomplished in the manner prescribed by the Constitution. If, on the other hand, this Court puts 'sex' in the same category as 'race' we will have assumed a decisional responsibility (not within the democratic process) unnecessary to the decision of this case, and at the very time that legislatures around the country are debating the genuine pros and cons of how far it is wise, fair and prudent to subject both sexes to identical responsibilities as well as rights.

Memorandum from Justice Lewis F. Powell to Justice William J. Brennan, Jr. 1 (Mar. 2, 1973) (William J. Brennan, Jr., Papers, Part 1:299, Folder 11, on file with the Library of Congress).

311. Memorandum from Justice Harry A. Blackmun to Justice William J. Brennan, Jr. 1 (Mar. 5, 1973) (William J. Brennan, Jr., Papers, Part I:299, Folder 11, on file with the Library of Congress).

312. Memorandum from Justice William J. Brennan, Jr., to Justice Lewis F. Powell (Mar. 6, 1973) (William J. Brennan, Jr., Papers, Part 1:299, Folder 11, on file with the Library of Congress) [hereinafter Memorandum from Brennan to Powell] ("Thurgood's discussion of Reed in his dissent to your [decision in San Antonio v.] Rodriguez convinces me that the only rational explication of Reed is that it rests upon the 'suspect' approach.").

313. Id.

314. Id. 
Frontiero signified a partial victory for the dual constitutional strategy. Brennan's opinion-and indeed the temporal proximity of judicial reinterpretation with congressional approval of the ERA-suggests that without the impetus provided by ERA advocacy, feminist litigation might not havc succeeded to the extent that it did. But as Justice Powell's concurrence vividly demonstrated, the simultaneous pursuit of the ERA cut both ways. More cautious justices were unwilling to circumvent Article V processes and prematurely declare sex equality. Justice Rehnquist, who as a DOJ official had equivocated about the ERA's desirability and predicted judicial reinterpretation of the Fourteenth Amendment, declined to participate in that reinterpretation, making him the lone dissenter in Frontiero. ${ }^{315}$

Having come up one justice short of establishing strict scrutiny as the standard of review for sex-based classifications, legal feminists renewed their commitment to the dual constitutional strategy. The failure to achieve a majority in Frontiero indicated that they could not count on the Court for an unequivocal endorsement of egalitarian principles; over the next several years, dogged ratification battles in recalcitrant states would reveal that the ERA was no less susceptible to the slings and arrows of political fortune. No longer crippled by internal dissension over the ERA as they had been in the 1960s, legal feminists of the 1970s could afford to be pragmatists. For better or for worse, they would pursue the dual strategy until the ERA's final demise in 1982.

\section{D. "What Harm Redundance?" Advantages and Pitfalls of the Dual Strategy}

When Dorothy Kenyon endorsed the dual strategy after decades of opposition to the ERA, she remarked that surely no harm could come from simultaneously pursuing Fourteenth Amendment litigation and a new amendment. "[I]f the new Amendment could act as a catalyst in getting clarification [through litigation] ... it too would be a blessing. Needless to say the Amendment (with the XIVth in its present condition) cannot be called unnecessary; and, even if it became so later, what harm redundance?"316 In contrast, ERA post-mortems by historians and political scientists place significant blame for the amendment's ratification failure on the success of efforts to achieve judicial reinterpretation of the Fourteenth Amendment. ${ }^{317}$ The gap between legal feminists' confident articulation of the dual strategy in the early 1970 s and these retrospective

315. See Frontiero v. Richardson, 411 U.S. 677, 691 (Rehnquist, J., dissenting) (relying on the reasoning of the district court, see Frontiero v. Laird, 341 F. Supp. 201 (M.D. Ala. 1972), which found a reasonable basis for the challenged military benefits laws).

316. Dorothy Kenyon, The Equal Rights Amendment 5 (n.d.) (unpublished draft of encyclopedia entry) (Dorothy Kenyon Papers, Box 23, Folder 17, on file with the Sophia Smith Collection, Smith College).

317. See, e.g., BERRY, supra note 9, at 99-100; MANSBRIDGE, supra note 9, at 48-59. 
evaluations of its effects on the ERA's prospects for ratification raises questions about the soundness of this strategy. This section examines how feminist lawyers grappled with the emerging dilemmas of the dual strategy throughout the remainder of the 1970s.

Initially, most feminists likely believed that the dual constitutional approach would be only a temporary expedient, not a long-term strategy. As many scholars of the ERA have noted, proponents utterly failed to anticipate the strength of the opposition they would face during the ratification process, in part because the STOP ERA campaign spearheaded by Phyllis Schlafly did not mobilize in full force until the 1973 Roe v. Wade decision galvanized anti-feminists. ${ }^{318}$ At the same time, legal feminists did not believe that a ratified ERA would end the need for litigation altogether; rather, they envisioned seeking further clarification of women's rights in the courts under the new amendment instead of under existing constitutional provisions. ${ }^{319}$ Once it became evident that the ratification battle would be of protracted duration and uncertain outcome, feminist legal strategists had to contend with the dilemmas their dual strategy precipitated.

Feminist lawyers and activists attempting to implement the dual constitutional strategy faced three primary conundrums. The first, described in the preceding section, involved the reluctance of some justices to circumvent the Article $V$ process and effectively enact the ERA through reinterpretation of the Equal Protection Clause. Feminists could and did continue to invoke the ERA's passage as an example of a congressional enactment that, like the Civil Rights Amendments of 1972, reflected a broad national consensus in favor of sex equality. However, the existence of an unratified constitutional amendment that would enact the change legal feminists sought raised important - and, in wake of Powell's Frontiero concurrence, unavoidable - questions of democratic legitimacy and accountability. Ruth Bader Ginsburg frequently attempted to turn the justices' reluctance to feminists' advantage by arguing that only an ERA would resolve the equality question in an unambiguous manner. In a 1976 speech, she explained the difficulties of relying solely on doctrinal development to achieve feminists' goals: "The Court must act with particular circumspection ... in the dim zone between constitutional interpretation (a proper judicial task) and

318. See, e.g., David E. Kyvig, Historical Misunderstandings and the Defeat of the Equal Rights Amendment, 18 PUB. Historian 45, 52-53 (1996).

319. See, e.g., Kenyon, supra note 316; Testimony of Thomas 1. Emerson on Ratification of the Equal Rights Amendment, Baton Rouge, Louisiana 11 (June 7, 1977) (Thomas Emerson Papers, 92-M56, Box 24, Folder: ERA-Current Basic Materials, file with the Sterling Memorial Library, Yale University) [hereinafter Testimony of Emerson on Ratification of the Equal Rights Amendment] ("The role of the courts in applying the Equal Rights Amendment will be no different than their function with respect to due process, equal protection, the First Amendment, or any other basic provision of the Constitution. Decision of issues on a case-by-case basis is a traditional method of effectuating legal change."). 
constitutional amendment (a job for federal and state legislatures)., ${ }^{, 320}$ Since the legislative history of the Civil War amendments admittedly suggested the Framers' indifference to sex equality, Ginsburg argued, the only gesture that would remove this historical impediment for all time was the enactment of an ERA. ${ }^{321}$

Ginsburg's argument for an ERA as a "signal"322 to courts that seemed to flounder in their attempts to enunciate a coherent constitutional principle was also responsive to legal feminists' second dilemma-how to continue to assert the ERA's necessity in spite of very real accomplishments in the litigation arena. One obvious solution was to emphasize the justices' ambivalence, inconsistency, and incoherence in addressing sex discrimination questions. In 1975, after a confusing and cryptic series of decisions left utterly ambiguous the Court's rationale for upholding some sex distinctions and not others, Ginsburg lamented, "Without ERA, I don't think we will see from this Supreme Court an articulated advance in theory." "323 Legal feminists did their best to turn court defeats into ERA victories. John $\mathrm{H}$. Fleming, a sympathetic Harvard Law Review editor, wrote to Ginsburg that same year that the Court's recent unfavorable decisions in Schlesinger v. Ballard ${ }^{324}$ and Kahn v. Shevin ${ }^{325}$ "at least have the merit of underscoring the need for the E.R.A." ${ }^{326}$ When the Supreme Court declared in Geduldig v. Aiello $^{327}$ that the Equal Protection Clause had nothing to say about discrimination based on pregnancy, Thomas Emerson boldly told the Connecticut General Assembly, which was considering rescission of the ERA, that "[w]hatever hope there may once have been of achieving equal rights for women through interpretation of the Fourteenth Amendment must now plainly be abandoned., 328

320. Ruth Bader Ginsburg, Speech to the ABA Section of Individual Rights and Responsibilities, The American Woman-200 Years Later 8-9 (Aug. I0, 1976) (Ruth Bader Ginsburg Papers, Container 20, Folder: Equal Rights Amend: American Bar Association, 1973-I980, on file with the Library of Congress).

32I. Id. at $\mathrm{I} 0-11$.

322. Ruth B. Ginsburg \& Kathleen W. Peratis, Editorial, Equal Rights for Women, N.Y. TIMES, Dee. 31, 1975, at 21 ("A clear signal, a counterpart to the one supplied for race by the 14th amendment, is needed to assure replacement of ad hoc decision-making by a coherent opinion pattern. The E.R.A. would supply that signal."); see also Ruth Bader Ginsburg, Let's Have E.R.A. as a Signal, A.B.A. J., Jan. 1977, at 70 (making same argument); American Civil Liberties Union, The Equal Rights Amendment: A Lifetime Guarantee (1976) (same).

323. Letter from Ruth Bader Ginsburg to Catherine East (Mar. 31, 1975) (Ruth Bader Ginsburg Papers, Container 7, Folder: Stevenson v. Castles: Correspondence, Jan.-Apr. 1975, on file with the Library of Congress).

324. 419 U.S. 498 (1975).

325. 4I6 U.S. 35 I (I974).

326. Letter from John H. Fleming to Ruth Bader Ginsburg (Jan. 18, I975) (Ruth Bader Ginsburg Papers, Container 4, Folder: Kahn v. Shevin, 1973-1975, on file with the Library of Congress).

327. 4I7 U.S. 484 (I974).

328. Statement of Thomas I. Emerson Before the Government Administration and Policy Committees of the Connectieut General Assembly on Proposed Resolution to Rescind Connecticut's 
This tactic-labeling the litigation route as hopeless-created a third predicament for feminists. While the cause of ERA advocacy might best be served by harshly criticizing the Court's equal protection jurisprudence, undermining the existing favorable precedents seemed unwise given the ERA's uncertain fate. Ginsburg recognized this problem early on and cautioned the Women's Rights Law Reporter in 1972 against publishing a critique of Reed that implied that the decision upheld old unfavorable precedents. ${ }^{329}$ Ginsburg argued that "[o]ne can support ERA with utmost vigor ... without resorting to a broadside that is not only inaccurate but also harmful in cases now pending." 330 Since the ERA was, in her estimation, " 3 , maybe 4 years away from becoming effective ... statements that Reed upholds old precedents . . . could be turned against women who seek relief now." 331 Citing lower court cases in which "the affirmative [aspects of Reed were] emphasized," Ginsburg indicated that she was committed to "using Reed for whatever positive value it can yield in pending litigation." 332 The juxtaposition of litigation tactics with ERA rhetoric contained an element of contradiction. Five years later, Fleming astutely observed in a letter to Ginsburg, "I note with bemusement how we both stress the consistencies and groundbreaking nature of recent Supreme Court equal protection decisions when arguing equal protection cases.... and find the same law to be in a thorough state of confusion when we speak to the need for an ERA." 333

When faced with skepticism on this point, feminists reminded critics that the ERA's legislative history revealed a common impression that existing constitutional provisions, if properly interpreted, would yield the same result as an amendment. In a 1972 court brief, the ACLU quoted one senator as stating the "general view" that "[i]f courts were to move forward with regard to interpreting the fourteenth amendment to afford true equal protection for women, the new amendment could be redundant." ${ }^{334}$ In her notes for oral argument before the Supreme Court in the 1976 case

Ratification of the Equal Rights Amendment (Mar. 1977) (Thomas Emerson Papers, 92-M-56, Box 24, Folder: ERA: Current Basic Materials, on file with the Sterling Memorial Library, Yale University); see also Testimony of Emerson on Ratification of the Equal Rights Amendment, supra note 319, at 9 ("One can only conclude that resort to the Supreme Court is a lost hope.").

329. Letter from Ruth Bader Ginsburg to Elizabeth Langer, Women's Rights Law Reporter (Apr. 14, 1972) (Ruth Bader Ginsburg Papers, Container 7, Folder: Reed v. Reed, 1972-1975, on file with the Library of Congress).

330. Id. at 1 .

331. Id.

332. Id.

333. Letter from John H. Fleming, Sutherland, Asbill \& Brennan LLP, to Ruth Bader Ginsburg (Sept. 2, 1977) (Ruth Bader Ginsburg Papers, Container 1, Folder: Equal Rights Amend.: American Bar Association, 1973-1980, on file with the Library of Congress).

334. Brief of Amici Curiae ACLU, Stuart v. Bd. of Supervisors of Elections, 295 A.2d 223 (Md. 1972) (No. 105), available at NOW LDEF Papers, 95-M79, Carton 5, Folder: TV11-Stevenson v. Castles, on file with the Schlesinger Library, Radcliffe Institute, Harvard University. 
Califano v. Goldfarb, Ginsburg wrote: "In Congress, ERA proponents as well as opponents shared the view that clarification of the [equal protection provision's] application to $\mathrm{s}$ [ex]-b[ased] discrimination was needed and should come from this Court ... Proponents believed appropriate jud[icial] interp[retation of the] 5 [th] and I4[th amendments] would secure equal rights for men and women." 335 In effect, she was arguing to the justices that the dual strategy was not clumsy or inconsistent, but an intentional and well-considered approach, and that even advocates committed to change through formal amendment had only resorted to such drastic measures because of misguided judicial intransigence that the Court had begun to remedy. The Court, she suggested, could continue this process of redemption without thwarting normal Article V procedures.

As Ginsburg's oral argument strategy indicates, the impact of the dual approach on feminists' Iegal fortunes during this decade was neither wholly negative nor strictly limited to effects on the ERA's chances for ratification. As Reva Siegel has argued, the social movement mobilizations that accompany many attempts at constitutional emendation do not automatically lose their legal and constitutional significance when they fail Article V's ratification test. ${ }^{336}$ Brennan's opinion in Frontiero suggests that as many as four justices believed that congressional approval of the ERA was a factor militating in favor of - not against-judicial reinterpretation of the Fourteenth Amendment. Had feminists not pursued litigation under the Fourteenth Amendment and had the ERA still failed, they might have relinquished all prospect of progress toward a constitutional sex equality norm. For all of its flaws, the dual strategy succeeded in preventing the Iegal arm of the women's movement from placing all of its eggs in one fragile constitutional basket.

\section{III}

\section{Legal Feminism's Constitutional LEgaCy}

Legal feminists' coalescence around the dual constitutional approach had profound and immediate substantive and strategic consequences, as Parts I and II have shown. Part III assesses the dual strategy's legacy, looking first at the paradoxical results of legal feminists' pragmatic approach to constitutional change, before turning to its resonances in current constitutional sex equality doctrine. The final section briefly suggests how this historical example may shed light on the constitutional choices facing advocates today.

335. ERA Notes (Ruth Bader Ginsburg Papers, Container 2, Folder: Califano v. Goldfarb, Oral Argument Notes and Related Material, 1976, on file with the Library of Congress).

336. Siegel, supra note 5. For an argument that the mode of constitutional change has proven irrelevant to long-term interpretive outcomes, see David Strauss, The Irrelevance of Constitutional Amendments, 114 HARv. L. REv. 1457 (2001). 


\section{A. The Paradoxes of Pragmatism}

Legal feminists' constitutional choices left a mixed legacy, both for constitutional sex equality jurisprudence and for the feminist movement itself. The dual strategy was, essentially, a pragmatic solution to the two problems legal feminists confronted in the 1960s: internal dissension and judicial intransigence. Once Murray and her allies convinced their compatriots, after years of careful diplomacy, that the Fourteenth Amendment and the ERA were complementary tools of change, the dual strategy united advocates who had for years labored separately and antagonistically. Indeed, the legal feminists' concerted effort to scuttle Senator Bayh's compromise proposal in 1970 demonstrated the degree to which once-reluctant individuals and organizations were committed to the dual strategy. This transformation of the dual strategy from expedient tactic to mobilizing tool reflected an intuition that attacking sex discrimination on multiple fronts offered greater chances for success than pinning legal feminists' hopes on formal amendment or judicial reinterpretation alone.

Both of these pragmatic rationales for uniting around a dual strategy led to somewhat paradoxical consequences. On the one hand, this historical account leaves no doubt of the centrality of intersectional perspectives to the development of American legal feminism. For Pauli Murray, the champion of a strategic approach to change, constitutional choices had profound consequences for the viability of interracial coalitions with the capacity to recognize the multiplicity of women's identities. Caught between a racial justice movement that often marginalized women and a legal feminism founded on racial exclusion, Murray and her allies forged a constitutional coalition capable of transcending decades of disunity and in no small part responsible for feminist coalescence around the dual strategy.

In the end, however, though reaching this consensus required jettisoning old feminist alliances with segregationists, convergence around the dual strategy ultimately meant losing the Fourteenth Amendment's intersectional promise and retaining the ERA's old, formalistic language and detachment from other forms of inequality, from reproductive rights, and from private discrimination. For her part, Murray never relinquished her hope that the Constitution would incorporate an expansive and inclusive affirmation of equality for all Americans, even after she left the law in the mid-1970s to become one of the first female clergy in the Episcopal Church. In her inaugural sermon as an ordained priest, delivered in 1977 in the North Carolina church where her enslaved grcat-grandmother had been baptized more than a century earlier, Murray offered a prayer for the speedy passage of the ERA in her state's legislature. ${ }^{337}$ When the ERA went down to defeat several years later, Murray proposed to NOW leaders

337. Ist Negro Woman Priest Holds Service in N.C., WASH. PosT, Feb. 25, 1977, at D14. 
a new Human Rights Amendment that would encompass all " "downtrodden, weak and subordinate' groups" so that "all minorities could come together in a coalition," and overcome feminism's persistent image as dominated by the interests of white, middle-class women. ${ }^{338}$ At seventy-three, Murray was still strategizing, but the time for amendment had come and gone.

In yet another paradox, the dual strategy had appealed to Fourteenth Amendment partisans precisely because a Nixonian Court seemed less likely to engage in a progressive reinterpretation of existing constitutional provisions, rendering an ERA necessary. But the very political impulse that counseled judicial restraint in an increasingly conservative climate sapped strength from the dual strategy, a weakness the Frontiero impasse soon exposed. Pursuing a dual strategy had the salutary effect of convincing the Court to embraee a heightened standard of review for sex-based classifications, but also provided a justification for stopping short of the strict scrutiny legal feminists sought. Legal feminists had the misfortune of reaching their political peak at the very moment that possibilities for social change through legal reform were constricting across the board. Nor did the old problem-women's inability to claim the "discrete and insular minority" status that justified judicial intervention on behalf of politically disadvantaged groups-disappear. Indeed, advocates like Ginsburg, the most prominent implementer of the dual strategy, were acutely aware of this dilemma. ${ }^{339}$

Notably, legal feminists' constitutional choices were not, in the first instance, driven by the considerations courts tend to privilege as indicia of the democratic legitimacy of change. As they formulated their strategy in the 1960s, feminists were preoccupied with negotiating the personal and political loyalties and prejudices that had long prevented a concerted effort to improve women's legal status. Once they finally agreed upon the dual strategy and presented it to Congress during the ERA debates, arguments about legitimacy rarely surfaced except in the testimony of law professors, relative latecomers to the legal feminist camp. This disjuncture between

338. Letter from Pauli Murray to Judy Goldsmith 1 (Nov. 30, 1983) (Pauli Murray Papers, MC 412, Box 125, Folder 2248, on file with the Schlesinger Library, Radcliffe Institute, Harvard University); see also Memorandum from Pauli Murray to Judith Goldsmith, Gloria Steinem, Marjoric Fine Knowles, Eleanor Holmes Norton, Marguerie Rawalt, Sonia Pressman Fuentes, Catherine East, Carolina F. Warc, Ann Fagan Ginger, Isabelle Katz Pinzler, Betty Friedan, Mary O. Eastwood, Kay Clarenbach, Re: A Proposed Human Rights Amendment to Replace the Campaign for ERA (Nov. 30, 1983) (Pauli Murray Papers, MC 412, Box 125, Folder 2248, on file with the Schlesingcr Library, Radcliffe lnstitute, Harvard University)

339. Ginsburg's training in the law at the height of the legal process school's influence likely made her particularly cognizant of such difficulties. Ginsburg was a student of Herbcrt Wechsler's at Columbia Law School in the 1950s, see Tamar Lewin, Herbert Wechsler, Legal Giant, Is Dead at 90 , N.Y. Times, Apr. 28, 2000, at C21, having previously studied with Henry Hart and Albert Sacks at Harvard, see William N. Eskridge, Jr. \& Philip P. Frickey, The Supreme Court, 1993 TermForeword: Law as Equilibrium, 108 HARV. L. REv. 27, 27 (1994). 
courts' and advocates' conception of the relationship between political action and the legitimacy of judicial reinterpretation of constitutional meanings may not be surprising, but it is revealing. If decisions about which modes of change to pursue are not based upon calculations about their relative legitimacy, and if formal amendment advocacy and litigation are not independent but rather are deeply intertwined, then assessments of which mode of change has the superior democratic pedigree must take into account advocates' constitutional choices and their consequences.

\section{B. The Dual Strategy's Legacies in Constitutional Sex Equality Jurisprudence}

The paradoxes described in the preceding section echo through constitutional sex equality jurisprudence to this day. The mercurial intermediate scrutiny standard is perhaps our most prominent souvenir of legal feminism's partial triumph. This Goldilocks solution, enshrined in Craig v. Boren, ${ }^{340}$ elaborated and arguably strengthened in subsequent cases culminating in United States v. Virginia, ${ }^{341}$ captures the Court's ambivalence about both the procedural and the substantive aspects of a revolution in gender roles. The limitations of intermediate scrutiny were on display in Nguyen $v$. INS ${ }^{342}$ in which the Court upheld a requirement that children born of American fathers and non-American mothers provide affirmative evidence of paternity not required of children born of American mothers and non-American fathers. Legal feminism's legacy is also visible in the Court's decision in Nevada Department of Human Resources v. Hibbs, ${ }^{343}$ a startling affirmation of congressional power under Section five of the Fourteenth Amendment to enact the Family Medical Leave Act. The dual strategy has thus contributed both to the sea change in sex discrimination jurisprudence that heightened scrutiny represented and to the limitations of that transformation.

\section{Vindication: United States v. Virginia}

It is difficult to overestimate the distance between the conception of gender roles articulated in the 1961 case Hoyt $v$. Florida and the new sex discrimination jurisprudence inaugurated in Reed and Frontiero in the early 1970s. The decision in Hoyt, which upheld Florida's exemption of women from compulsory jury service, was not the work of political reactionaries-indeed, the unanimous Court included Justices Brennan, Black, Douglas, Warren, and Stewart. For Hoyt's author, Justice Harlan, excepting women from the civic obligation of jury service flowed naturally from the 
assumption that women's essential social location had always been and would always be "at the center of home and family life." ${ }^{344}$ Hoyt also logically followed the Court's twentieth-century solicitude for sex-based protective labor laws, designed to shield working women from exploitation and preserve their ability to care for their families. The assumptions that women, but not men, were responsible for caretaking duties in the homeand that men, but not women, should bear the burden of familial financial support-were the target of women's rights advocates by the 1970s. It was these assumptions that Ginsburg and her colleagues sought to eradicate through challenges to laws that asymmetrically allocated benefits and reinforced sex-based dependencies.

On the one hand, congressional approval of the ERA and of other antidiscrimination legislation, spurred by agitation from the women's movement, clearly played an important role in swaying the justices away from their protectionist precedents. Brennan's plurality opinion in Frontiero suggests that the ERA's pendency moved at least four justices to the view that, as Brennan put it in a memorandum to Powell, "the 'suspect' approach is the proper one and ... further ... now is the time, and this is the case, to make that clear. ${ }^{.345}$ Freely admitting that the ERA's prospects for ratification were dim, Brennan couldn't "see that we gain anything by awaiting what is at best an uncertain outcome." ${ }^{346}$ Decisive congressional action on the subject was enough for Justice Byron White, too. He wrote to his colleagues during the Frontiero deliberations: "I would think that sex is a suspect classification, if for no other reason than the fact that Congress has submitted a constitutional amendment making sex discrimination unconstitutional." ${ }^{347}$ White went on to declare that he "would remain of the same view whether the amendment is adopted or not." ${ }^{9348}$ The language of the Frontiero plurality opinion is likewise unambiguous on this point, making clear that the Court's newfound recognition of a "long and unfortunate history of sex discrimination" 349 was indebted to unprecedented, tangible congressional support of an antidiscrimination principle. It also seems likely that the backdrop of legislative solicitude for women's rights influenced the justices who went along with the result in Frontiero without endorsing strict scrutiny. Absent the women's movement's renaissance and its legislative manifestations, it is hard to imagine Justices Burger,

344. Hoyt v. Florida, 368 U.S. 57, 62 (1961).

345. Memorandum from Brennan to Powell, supra note 312 , at 1.

346. Id.

347. Memorandum from Justice Byron R. White to Justice William J. Brennan, Jr. (Feb. 15, 1973)

(William J. Brennan, Jr., Papers, Part 1:299, Folder 11, on file with the Library of Congress).

348. Id.

349. Frontiero v. Richardson, 411 U.S. 477, 684 (1973). 
Blackmun, Stewart, and Powell spontaneously responding to feminist lawyers' arguments. ${ }^{350}$

On the other hand, the dual strategy may also have limited legal feminist success by restraining the Court from effectively enacting the ERA's substance through a reinterpretation of the Fourteenth Amendment. The extent to which the ERA's pendency was responsible for the reluctance of Powell, Burger, and Blackmun to endorse strict scrutiny in Frontiero is, of course, impossible to measure. Substantive misgivings about granting sexbased classifications the same level of review as classifications based on race may well have underlay the concurring justices' procedural objection. Still, in a political climate increasingly hostile toward judicial overreaching, Powell's concern that "democratic institutions are weakened, and confidence in the restraint of the Court is impaired, when we appear unnecessarily to decide sensitive issues of broad social and political importance at the very time they are under consideration within the prescribed constitutional processes" ever these justices' motivations, there is no question that their processfocused vision of constitutional change was a politically viable rationale for holding back, one cognizable in the legal discourse of the day. ${ }^{352}$

The result of this impasse was the middle-ground standard articulated in Craig. ${ }^{353}$ Intermediate scrutiny, cryptically introduced in an uninspiring case about two-percent beer, split the difference between the strictest standard of review-embodied in the ERA and in advocates' interpretation of the Fourteenth Amendment - and the old rational basis standard that permitted most sex-based distinctions as a logical outgrowth of disparate gender roles and immutable physical differences. Henceforth, sex-based classifications were required to be "substantially related" to "important governmental objectives." 354 This compromise has often been rationalized as a recognition of the limitations of the race-sex analogy, a nod to the fact that while racial differences are mutable, socially constructed, or imaginary, sex differences are in some way "real" or biologically determined. ${ }^{355}$

350. See Siegel, supra note 5, at 308-13 (arguing that feminist mobilization behind an ERA was a crucial impetus for judicial reinterpretation of the Equal Protection Clause); Eskridge, Jr., Channeling, supra note 5, at 502 ("The power of the women's movement was such that the Court felt impelled in the 1970 s to rule unconstitutional most invidious sex discriminations.").

351. Frontiero, 411 U.S. at 692 (Powell, J., concurring in the judgment).

352. Cf. Jed Rubenfeld, The Anti-Antidiscrimination Agenda, 111 YALE L.J. 1141 (2002) (arguing that the Rehnquist's Court's jurisprudence is motivated more by substantive opposition to an "antidiscrimination agenda" than by federalism and other doctrinal values the Court's majority invokes to support its decisions).

353. Craig v. Boren, 429 U.S. 190 (1976).

354. Id. at 197.

355. See, e.g., United States v. Virginia, 518 U.S. 515, 533 (1996) ("Supposed 'inherent differences' are no longer accepted as a ground for race or national origin classifications. Physical diffcrences between men and women, however, are enduring." (citation omitted)); Sullivan, supra note 13 , at 745 . 
Politically, though, intermediate scrutiny was also a compromise between Justice Brennan's effective embrace of legal feminism's dual strategy, and the position of justices who, like Justice Powell, believed that the ERA's pendency counseled restraint. ${ }^{356}$

A majority of the Court endorsed a more muscular "skeptical scrutiny" in United States $v$. Virginia, in which the Court invalidated the Virginia Military Institute's (VMI) policy excluding female students. ${ }^{357}$ Now-Justice Ginsburg wrote for the majority, "Inherent differences' between men and women, we have come to appreciate, remain cause for celebration, but not for denigration of the members of either sex or for artificial constraints on an individual's opportunity." 358 Sex classifications were permissible if designed to compensate women for historic inequalities and to promote equal opportunity in the present. ${ }^{359}$ However, Ginsburg continued, "[S]uch classifications may not be used, as they once were, to create or perpetuate the legal, social, and economic inferiority of women." 360

Not all the justices agreed. Chief Justice Rehnquist, while concurring in the judgment, protested the majority's augmentation of intermediate scrutiny and insisted upon the viability of a "separate-but-equal" female alternative to VMI. ${ }^{361}$ Justice Scalia issued a vitriolic dissent in which he suggested that if the Court were in the mood to rethink the standard of scrutiny for gender-based classifications, a downward departure to rational basis review was more appropriate. ${ }^{362}$ Still, with its six-justice majority, Virginia represented a triumph for Justice Ginsburg, an almost complete vindication of her 1970 s crusade. VMI's all-male policy was a paradigm example of the type of exclusion that Ginsburg's litigation campaign sought to vanquish: the denial of a valuable educational and economic opportunity based upon generalizations about women that might be applicable on average, but unfairly restricted the choices of individuals who wished to flout the norm. And the new "skeptical scrutiny," with its emphasis on the importance of an "exceedingly persuasive justification" for any sex-based legal classification, seemed to win for women the benefits of strict scrutiny without the drawbacks attendant to such a standard in the

356. Indeed, the Hibbs opinion cites Craig for the proposition that sex-based classifications, unlike those based on age and disability, are subject to heightened scrutiny. See Nev. Dep't of Human Res. v. Hibbs, I23 S. Ct. 1972, I978 (2003).

357. 5 I 8 U.S. 5I5, 53 I (I996).

358. Id. at 533 .

359. Id.

360. Id. at 534 (eitation omitted).

360. Id. at 558-66 (Rehnquist, J., concurring).

362. Id. at 566-603 (Scalia, J., dissenting). Justice Thomas was recused, presumably because his son attended VMI. See Donald P. Baker, By One Vote, VMI Decides to Go Coed, WASH. Post, Sept. 22, I996, at AI. 
post-Adarand era. ${ }^{363}$ Ginsburg herself declared to a student audience shortly after Virginia was decided, "There is no practical difference between what has evolved and the ERA." 364

\section{Constrained Constitutional Choices: Nguyen v. INS}

Nguyen $v$. INS, on the other hand, illustrated both the limitations of intermediate scrutiny as a reliable guarantor of sex-based equal protection and the lost promise of alternative paths to constitutional equality forsaken when legal feminists coalesced behind the dual strategy. In Nguyen, the Court upheld an immigration statute allowing the offspring of unmarried citizen mothers and non-citizen fathers to be naturalized automatically but requiring children of unmarried citizen fathers and non-citizen mothers to provide evidence of paternity. ${ }^{365} \mathrm{~A}$ majority ruled that the law did not contravene equal protection because its distinction between mothers and fathers was substantially related to two important governmental objectives: first, ensuring the existence of a biological parent-child relationship, a connection automatically verifiable in the case of mothers but not fathers; and second, creating an opportunity for a parent-child relationship to develop-an opportunity inherent in biological motherhood but not in biological fatherhood. Since the law's differential treatment of noncitizen mothers and non-citizen fathers was "based on the significant difference between their respective relationships to the potential citizen at the time of birth,"366 it was "not marked by misconception and prejudice," $" 367$ and thus was "neither surprising nor troublesome from a constitutional perspective."368 Justice O'Connor's dissent, joined by Justices Ginsburg, Breyer, and Souter, chastised the majority for applying

363. See Adarand Constructors, Inc. v. Pena, 5I5 U.S. 200 (1995) (applying strict scrutiny to invalidate a race-based affirmative action program).

364. See Jeffrey Rosen, The New Look of Liberalism on the Court, N.Y. Times MAG., Oct. I, $1997, \S 6$, at 60 .

365. Nguyen v. INS, 533 U.S. 53 (2001). The challengcd statute imposed four requirements concerning unmarried citizen fathers that had to be satisfied in order to confer citizenship on a child born, out of wedlock, to a non-citizen mother abroad:

(1) a blood relationship between the person and the father is established by clear and convincing evidence,

(2) the father had the nationality of the United States at the time of the person's birth,

(3) the father (unless deceased) has agreed in writing to provide financial support for the person until the person reaches the age of 18 years, and

(4) while the person is under the age of 18 ycars-

(A) the person is legitimated under the law of the person's residence or domicile,

(B) the fathcr acknowledges paternity of the person in writing under oath, or

(C) the patemity of the person is established by adjudication of a compctent court.

8 U.S.C. $\$$ I 409(a) (2000).

366. Nguyen, 533 U.S. at 62.

367. Id. at 73 .

368. Id. at 63 . 
an impotent version of intermediate scrutiny that vitiated the "depth and vitality" of the Court's sex discrimination precedents. ${ }^{369}$ The challenged statute, the dissenters argued, was "paradigmatic of a historic regime that left women with responsibility, and freed men from responsibility, for non-marital children." 370

Nguyen signaled the vulnerability of the robust version of intermediate scrutiny applied in Virginia and epitomized the standard's inherent malleability. If the challenged citizenship law had distinguished between parents on the basis of race rather than sex, some commentators noted, the result reached by the Court in Nguyen would be virtually unimaginable. ${ }^{371}$ If legal feminists had succeeded in winning strict scrutiny for sex-based classifications, either through the ERA or the Equal Protection Clause, the law upheld in Nguyen would likely have fallen-for its lack of narrow tailoring, if not for the absence of a compelling governmental interest. At the very least, the Court would have been forced to justify the application of a more deferential standard to sex-based classifications in the immigration context.

Moreover, under more expansive versions of constitutional sex equality considered and rejected by legal feminists in the 1960s, the Nguyen majority's reasoning would have been significantly more difficult to justify. The Nguyen Court suggested that the Equal Protection Clause demands like treatment only where persons are "similarly situated." 372 Since "[f]athers and mothers are not similarly situated with regard to the proof of biological parenthood," the Court found that "differential treatment is inherent in a sensible statutory scheme." ${ }^{373}$ Had the reigning definition of constitutional sex equality included reproductive freedom for women, a legal distinction premised upon the "unique relationship of the mother to the event of birth" 374 would more likely have triggered greater, not lesser, constitutional concern. ${ }^{375}$

Further, had constitutional sex equality doctrine developed from a cognizance of the profound interconnectedness between sex and other forms of inequality, the Court-or at least its dissenters-might have focused on how the challenged law not only assumed that mothers bear the

369. Id. at 97 (O'Connor, J., dissenting).

370. Id. at 92 (O'Connor, J., dissenting).

371. See, e.g., Eskridge, Jr., Some Effects, supra note 5, at 2259 ("The Court's disposition also reflects the continued difference between race and sex distinctions in equality jurisprudenee. Is there much doubt that the Court would have overtumed a law making one's eitizenship turn in any way on the race of one's American (or non-American) parent?").

372. Nguyen, 533 U.S. at 63.

373. Id. at 63-64.

374. Id. at 64

375. Ginsburg, of eourse, has famously argued that reproductive rights might best have been granted based upon sex equality rather than merely a right of privacy. See Ruth Bader Ginsburg, Some Thoughts on Autonomy and Equality in Relation to Roe v. Wade, 63 N.C. L. REv. 375 (1985). 
primary responsibility for child rearing, but also burdened foreign-born mothers with a presumption of parental responsibility in a way that neither citizen-mothers nor foreign-born fathers were burdened. ${ }^{376}$ Citizenmothers, though saddled with primary legal responsibility for their children, could at least automatically transmit citizenship to them, and foreign-born fathers need not take any responsibility for their progeny for them to be naturalized. Foreign-born mothers, on the other hand, could rely neither on a presumption of paternal responsibility nor on the transmission of citizenship to their children when the citizen-father was, literally or figuratively, missing in action. Like the African-American women plaintiffs in White v. Crook, who suffered a unique form of disenfranchisement as a result of their race and sex, Nguyen's mother was a potentially potent symbol of the hardships borne by non-citizen women who shoulder full legal responsibility for children fathered by American men, often military servicemen. The situation of Nguyen's mother was not, of course, directly before the Court. ${ }^{377}$ Nevertheless, had Gardenia White become the Linda Brown of sex equality jurisprudence, Ms. Nguyen's plight might have resonated with the justices. ${ }^{378}$

\section{The Creation of Constitutional Culture: Nevada Department of} Human Resources v. Hibbs

The dual strategy's legacy lies not only in the redefinition of sex discrimination under Section one of the Fourteenth Amendment; it also laid the procedural groundwork for the Supreme Court's affirmation of Congress's power to enact prophylactic anti-sex discrimination legislation under Section five of the Fourteenth Amendment. In Nevada Department of Human Resources $v$. Hibbs, the Court surprised many observers by ruling that the FMLA was a valid exercise of congressional power under Section five to combat sex discrimination. One startling aspect of the majority opinion was its strikingly broad definition of constitutionally cognizable sex discrimination, a definition that encompassed "stereotype-based beliefs about the allocation of family duties" that disproportionately

376. For a searching discussion of the assumptions about maternal and paternal responsibility underlying judicial treatment of the law upheld in Nguyen, see Kristin Collins, Note, When Fathers' Rights Are Mothers' Duties: The Failure of Equal Protection in Miller v. Albright, 109 Yale L.J. 1669 (2000).

377. See Miller v. Albright, 523 U.S. 420, 451 (1998) (O'Connor, J., concurring in the judgment) (noting that it is unclear whether an alien may assert constitutional objections wbile outside the United States, and that an injury arising from discrimination "accords a basis for standing only to those persons who are personally denied equal treatment by the challenged discriminatory conduct" (citation omitted)). The reasoning of sex discrimination cases often involves a consideration of persons not before the Court, however. See, e.g., Weinberger v. Wiesenfeld, 420 U.S. 636 (1975) (considering the impact of discriminatory social security benefit allocation on plaintiff's deceased wife).

377. Gardenia White was the lead plaintiff in White v. Crook, Linda Brown was the child whose name is memorialized in Brown v. Board of Education. 
disadvantage women in "situations in which work and family responsibilities conflict." 379 Another was its author. Chief Justice Rehnquist delivered the opinion of the Court, joined by the four justices who had dissented, with increasing vehemence, from earlier rulings curtailing congressional power to abrogate state sovereign immunity through age and disability discrimination legislation. The lone dissenter in Frontiero-not to mention the leader of the Court's judicial supremacist wing-now upheld a law on arguably less evidence of present-day discrimination than was offered in Kimel, ${ }^{380}$ Morrison, ${ }^{381}$ and Garrett, ${ }^{382}$ cases where the Court found that Congress lacked Section five power to apply the challenged legislation against the states. In doing so, Rehnquist relied upon the heightened scrutiny afforded sex-based classifications - in contrast to age- and disability-related distinctions-under Craig and its progeny.

Hibbs, like Virginia, vindicated Ginsburg's substantive vision of sex equality. While Virginia emphasized the injustice of group-based generalizations to individuals defying gender-role stereotypes, Hibbs stressed how government policies perpetuated gender-based caretaking roles and exacerbated their disproportionate burden on women's employment opportunities. ${ }^{383}$ Less obviously, though, Hibbs also reaffirmed what might be called the procedural legacy of 1970 s legal feminism. As Robert Post persuasively argues, the Court's decision in Hibbs relies on a sex discrimination jurisprudence derived not from the judicial supremacist ethos to which the Court pays lip service, but from a line of cases heavily influenced by legislative branch action. ${ }^{384}$ As Post puts it, Hibbs's "extraordinarily generous account of the constitutional harm of sex discrimination" 385 finds its roots in the political and jurisprudential developments of the 1970 s, when a plurality of the Court acknowledged, in Frontiero, its own "debt to Congress's articulation of the transformation in national understandings of the significance of sex discrimination." 386 Though the Court's decisions in City of Boerne v. Flores ${ }^{387}$ and its progeny "forcefully repudiated" the "dialectical relationship between constitutional law and constitutional culture," Post points out that the jurisprudential underpinnings of Hibbs are

379. Robert C. Post, The Supreme Court, 2002 Term-Foreword: Fashioning the Legal Constitution: Culture, Courts, and Law, 117 HaRv. L. Rev. 4, 17 (2003) (quoting Nev. Dep't of Human Res. v. Hibbs, 123 S. Ct. 1972, 1979 \& n.5 (2003)).

380. Kimel v. Florida Bd. of Regents, 528 U.S. 62 (2000).

381. United States v. Morrison, 529 U.S. 598 (2000).

382. Bd. of Trs. of Univ. of Alabama v. Garrett, 531 U.S. 356 (2001).

383. Hibbs also vindicated Mary Anne Case's identification of anti-stereotyping as the unifying principle of constitutional sex equality jurisprudence. See Mary Anne Case, "The Very Stereotype the Law Condemns": Constitutional Sex Discrimination Law as a Quest for Perfect Proxies, 85 CoRnelL L. REv. 1447 (2000).

384. Post, supra note 379 , at $25-26$.

385. Id. at 17 .

386. Id. at 25-26.

387. 521 U.S. 507 (1997). 
dependent upon changes wrought by the influence of constitutional culture. ${ }^{388}$

As this Article has demonstrated, Frontiero and its progeny derived from a deliberate legal feminist strategy to pursue equality under the ERA and the Fourteenth Amendment simultaneously. By embracing heightened scrutiny as a justification for allowing Congress wider latitude to combat discrimination through legislation, the Court not only ratified the substance of the 1970s sex equality transformation, but also drew upon the dual strategy's model of dialectical interaction between the legislative and judicial branches in implementing constitutional change. For developments in the legislative and political spheres to influence judicial interpretation of the Constitution is not new, of course. ${ }^{389}$ But the legal feminists' embrace of the dual strategy, combined with the strategy's considerable success in a political climate increasingly hostile to judicial overreaching, forced the Court to confront the dialectical model head-on. The Frontiero impasse made the terms of the debate over the relationship between constitutional culture and jurisprudence explicit, but even the justices who eschewed the plurality's view implicitly accepted a moderated version of the dialectical model that legal feminists promoted through their dual strategy. ${ }^{390} \ln$ its reliance on the 1970s sex discrimination cases to broadly construe congressional power under the Fourteenth Amendment, then, Justice Rehnquist's opinion in Hibbs might be read as implicitly accepting not only the substantive content of those precedents, but their origins in legal feminists' dual strategy.

\section{Current Constitutional Controversies and the Lessons of History}

As the legal feminist experience makes clear, constitutional choices and their consequences are both highly contingent and historically particular. Where context is so vitally important both to options and to outcomes, the degree to which an historical episode can be generalized is necessarily limited. As such, this final section reflects upon the similarities and the differences between the choices facing legal feminists in the 1960s and 1970 s, and those confronting contemporary advocates of constitutional change. This discussion, which is meant to be suggestive rather than exhaustive, will refer to two current constitutional controversies-those

388. Post, supra note 379 , at 25-29.

389. Indeed, legal feminists are not the only advocates to have pursued a dual constitutional strategy. Earlier in the twentieth ccntury, opponents of child labor and proponents of the income tax followed a similar path, and both eventually succeeded in altering the constitutional landscapc. For more on these crusades, see Berry, supra note 9; Stephen B. Wood, Constitutional Politics in the Progressive Era: Child Labor and the Law (1968); Bruce Ackerman, Taxation and the Constitution, 99 Colum. L. REv. 1 (1999).

390. Cf. Eskridge, Jr., Channeling, supra note 5, at 503 (noting that "social movements can contribute to changes in the doctrinal structure of constitutional inquiry"). 
concerning reproductive freedom and gay rights. While the historical particularity of social movements and their political and legal contexts means that specific strategic challenges will inevitably differ, the interplay between various modes of legal change and the reciprocal impact of constitutional choices on internal social movement dynamics are common to today's debates.

Many of the practical difficulties associated with dual constitutional strategies are likely to extend beyond the particular context of legal feminism. Ironically, the present-day dilemma most similar to that of the legal feminists may be the predicament faced by anti-abortion advocates who seek constitutional recognition of fetal rights. Activists opposed to abortion have promoted constitutional amendments declaring that human life begins at conception since the mid-1970s. ${ }^{391}$ At the same time, they have lobbied for restrictions on abortion at the state and federal levels and argued for a reinterpretation of existing constitutional provisions. Fighting to overturn Roe v. Wade while attempting to pass a constitutional amendment is a dual strategy with similar drawbacks to the legal feminists' approach. As one pro-life proponent puts it, the proposed Human Life Amendment (HLA) is a "double-edged sword." 392 From an anti-abortion perspective, the amendment "may preserve human life and diminish the culture of death." ${ }^{393}$ But some might "consider HLA a tacit approval of the construction of the Due Process Clause that has produced Roe and Dred Scott," with consequences not only for the jurisprudence of abortion, but also for the death penalty, assisted suicide, euthanasia, and infanticide. ${ }^{394}$ Seeking Article V amendment, in other words, may carry with it the implication that reigning constitutional interpretations are correct. On the other hand, the success of such

391. See, e.g., Republican National Committee, Republican Platform: Prosperity, Self Government and 'Moral Clarity,' 52 Cong. Q. AlmanaC D-21, D-28 (1996) ("The unborn child bas a fundamental individual right to life which cannot be infringed. We support a human life amendment to the Constitution and we endorse legislation to make clear that the Fourteenth Amendment's protections apply to unborn children."); Human Life Amendment, S. 158, 97th Cong. $\$ 1$ (1981), providing:

The Congress finds that present day scientific evidence indicates a significant likelihood tbat actual human life exists from conception. The Congress further finds that the fourteenth amendment to the Constitution of the United States was intended to protect all human beings. Upon the basis of these findings, and in the exercise of the powers of the Congress, including its power under section 5 of the fourteenth amendment to the Constitution of the United States, tbe Congress hereby declares that for the purpose of enforcing the obligation of the States under the fourteenth amendment not to deprive persons of life without due process of law, human life shall be deemed to exist from conception, without regard to race, sex, age, health, defect, or condition of dependency, and for this purpose 'person' shall include all human life as defined herein.

392. Paolo Torzilli, Note, Reconciling the Sanctity of Human Life, the Declaration of Independence, and the Constitution, 40 CATH. LAW. 197, 225 (2000); see Human Life Amendment, supra note 391

393. Id. (internal quotation marks omitted).

394. Id. 
an amendment in gaining congressional backing could also strengthen the case for judicial reinterpretation of existing constitutional provisions under a dialectical model of constitutional change.

Despite sharing some of the practical difficulties legal feminists faced in advancing a dual strategy, anti-abortion advocacy lacks some of the key characteristics of legal feminism. For one, although anti-abortion advocates themselves are not a beleaguered, discrete and insular minority entitled to Carolene Products protection, they claim to speak for one-namely, unborn children. They may avoid, therefore, the legal feminists' dilemma of claiming judicial solicitude despite numerical majority status. Further, abortion opponents - at least those who are willing to accept a renunciation of Roe without an absolute protection of fetal rights - may style themselves as traditionalists, seeking not a revolutionary new interpretation of the Constitution, but rather a restoration of its rightful meaning. This is a significant advantage because it enables anti-abortion advocates to steer clear of accusations that the constitutional change they seek through litigation lacks democratic legitimacy. In fact, they can and do argue exactly the opposite - that they are seeking to reverse an illegitimate, anti-majoritarian episode of judicial aggrandizement. Advocates of reproductive freedom, on the other hand, are left to defend the constitutional status quo without the presumptive legitimacy preservationists usually enjoy.

Theoretically, one could also imagine advocates of gay rights pursuing a dual constitutional strategy-seeking an amendment prohibiting discrimination on the basis of sexual orientation while litigating for recognition of their rights under the Equal Protection Clause. Of course, lesbians' and gay men's status as a numerical minority makes this a less attractive strategy than it was for feminists. ${ }^{395}$ Still, although gay rights advocates have not promoted an amendmont to the federal Constitution, they have simultaneously pursued rights-securing legislation and judicial reinterpretation of existing constitutional provisions at both the state and federal levels. ${ }^{396}$ And gay rights advocates might have more success pursuing dual constitutional strategics in selected states where there is more support

395. Some scholars have argued that constitutional amendment is no longer a viable or desirable mode of achieving constitutional change. See, e.g., Eskridgc, Jr., Channeling, supra note 5, at 499. Kathleen Sullivan has argued that constitutional amendment is often unwise and in some cases may be counterproductive for advocates. Kathleen M. Sullivan, Constitutional Constancy: Why Congress Should Cure Itself of Amendment Fever, 17 CARDozo L. REv. 691, 704 (1996). Others, like David Kyvig, warn that without formal textual emendation, constitutional change is ephemeral. See DAvid E. Kyvig, Explicit and Authentic Acts: Amending the U.S. Constitution, i 776-i 995 (1996). On the constitutional amendment process more generally, see RESPONDING To IMPERFECTION: ThE Theory and Practice of Constitutional amendment (Sanford Lcvinson ed., 1995); John R. Vile, The Constitutional Amending Process in American Political Thought (1992).

396. In an intriguing development, the constitutional battle over gay rights is also being fought at the local level, as city and county officials defy state laws by granting marriage licenses to same-sex couples. See Michael Hill, Judge Tells New Paltz Mayor to Halt Same-Sex Marriages, Philadelphia INQUIRER, Mar. 6, 2004, at A3. 
for equality and where antidiscrimination legislation has been enacted at the state level. ${ }^{397}$

Anti-gay advocates are pursuing what might be called a dual strategy, but to advance a preservationist, rather than a progressive, agenda for constitutional change. Anti-gay groups have sponsored initiatives aimed at preventing same-sex marriage; scuttling domestic partnership laws; preserving the prerogatives of public and private entities to discriminate on the basis of sexual orientation in employment, housing, education, and other benefits; preventing the enactment of antidiscrimination legislation; and more. They have done so through federal, state, and local legislation, through proposed federal and state constitutional amendments, and through litigation positions defending conservative judicial interpretations of existing constitutional provisions. ${ }^{398}$ Unlike gay rights and anti-abortion advocates, anti-gay activists do not claim to speak on behalf of a discrete and insular minority. But like the anti-abortion movement, anti-gay groups claim the mantle of democratic legitimacy, and more than abortion opponents, they argue for the constitutional status quo. Thus, while they may confront the practical problem of arguing for a constitutional amendment to establish a principle they claim is already constitutionally secured, anti-gay advocates do not face the same obstacles as do proponents of progressive constitutional change.

Identity-based or not, progressive or preservationist, majority or minority, all advocates seeking constitutional change must grapple with the difficulties associated with uniting diverse groups of activists behind a coherent constitutional and political agenda. In this way, the legal feminist experience is a cautionary tale. Legal feminists' abandonment of more expansive visions of constitutional change highlights how the internal dynamics of social movements, interacting with external political imperatives, may reduce activists' aspirations to their lowest common denominator. ${ }^{399}$ For legal feminists, that meant compromising definitions of constitutional sex equality that encompassed reproductive rights, explicitly embraced racial and economic diversity, and prohibited private

397. See, e.g., Goodridge v. Dep't of Pub. Health, 798 N.E. 2d 941 (2003). Of course, judicial reinterpretation of existing state constitutional provisions carries with it cnormous political risks, galvanizing opposition including, in the case of same-sex marriage, a federal constitutional amendment counterinsurgency. See Elisabeth Bumiller, Bush Backs Ban in Constitution on Gay Marriage, N.Y. Times, Feb. 25, 2004, at A1.

398. For a survey of such efforts, see the National Gay and Lesbian Task Force, Marriage Center, at http://www.ngltf.org/marriagecenter/index.cfm (last visited Mar. 9, 2004); see also James Dao, State Action is Pursued on Same-Sex Marriage, N.Y. Times, Feb. 27, 2004, at A24.

399. Eskridge has argued persuasively that a "clever judicial strategy ... channels [a social] movement's discourse in assimilative directions." See Eskridge, Jr., Channeling, supra note 5, at 423. The legal feminist story suggests that in formulating legal strategy, social movements themselves may begin this process of assimilative channeling. Cf. Risa L. Goluboff, "We Live's in a Free House Such as It Is": Class and the Creation of Modern Civil Rights, 151 U. PA. L. REv. 1977 (2003) (uncovering class-based claims the NAACP did not pursue in the 1940s). 
discrimination. In the context of the broader women's movement, the alternative visions left behind were well within the mainstream of feminism, ${ }^{400}$ but they nevertheless appeared threatening to the older, more conservative women who had long carried the banner of formal legal equality. Losing the support of those women, the time-honored liaisons between legal feminism and Congress, in turn threatened the political viability of proposed constitutional changes.

Coalition-building imperatives entail analogous costs for contemporary social movements. Advocates concerned with the status of gay, lesbian, bisexual, and transgendered Americans are a famously diverse group with widely varying ideological perspectives and practical priorities. The extent to which legal advocacy organizations concentrate resources on legalizing same-sex marriage may not only limit the time and money available to other causes, but also tends to privilege particular notions of equality over others. Many queer theorists and some gay rights legal advocates have criticized the pro-gay marriage movement as narrow, assimilationist, and oppressive of alternative sexualities. ${ }^{401}$ The marginalization of these other conceptions of equality and freedom may be the cost of consensus. On the other hand, just as the legal feminists' constitutional strategizing reconfigured old internal divisions and reshaped the meaning of equality, the political connotations of same-sex marriage may be transformed through constitutional contestation. As some conservatives level increasingly vituperative attacks against lesbian and gay relationships, gay rights advocates may not only put their own differences aside, but also may redefine marriage as a transformative, rather than merely traditional or assimilative, institution. ${ }^{402}$ For, as the legal feminist experience reveals, constitutional choices are also profoundly constitutive. Not only do advocates' choices shape the conceptions of equality available to courts and other

400. More radical and separatist feminist theories often eschewed the legal system altogether. For more on radical feminism, see, for example, EchOLS, supra note 173. Eskridge argues that equal protection doctrine itself privileged social movement moderates at the expense of radicals. See Eskridge, Jr., Channeling, supra note 5, at 487-88. For an argument that the radical/liberal feminist dichotomy was more fluid than movement historians have generally recognized, see Deborah Dinner, Transforming Family and State: Women's Vision for Universal Childcare, 1966-1971 (2004) (unpublished manuscript, on file with author).

401. For a sampling of views, see William N. Eskridge, JR., The Case for Same-Sex Marriage: From Sexual Liberty to Civilized Commitment (1996); Michael Warner, The Trouble With Normal: Sex, Politics, and the Ethics of Queer Life (1999); Douglas NeJaime, Note, Marriage, Cruising, and Life in Between: Clarifying Organizational Positionalities in Pursuit of Polyvocal Gay-Based Advocacy, 38 HARv. C.R.-C.L. L. REv. 511 (2003); Evan Wolfson, Crossing the Threshold: Equal Marriage Rights for Lesbians and Gay Men and the Intra-Community Critique, 21 N.Y.U. Rev. L. \& Soc. Change 567 (1994); Kenji Yoshino, Covering, 111 Yale L.J. 769 (2002).

402. See Tamar Lewin, Marriage-Minded: The Gay Rights Movement, Settled Down, N.Y. TimES, Feb. 29, 2004, $\S 4$, at 5 (quoting sexuality historian George Chauncey, who notes that "[m]arriage can look like the most assimilationist gesture possible or, as has become obvious from the reaction, like the most transgressive and revolutionary gesture."). 
decisionmakers, but the act of choosing between constitutional options also constructs the social movements that mobilize for change.

\section{CONCLUSION}

In coalescing around a dual constitutional strategy, legal feminists overcame internal divisions, abandoned reprehensible alliances, and fashioned a coherent agenda for change. Though they relinquished racialist reasoning, they also sacrificed more expansive visions of equality at the altar of unity and prudence. Their pragmatic approach to constitutional revision succeeded in unifying disparate factions but created new practical dilemmas. Simultaneous litigation and amendment advocacy, while mutually reinforcing to some, was procedurally problematic to others. Legal feminists' dual strategy, with all of its triumphs and shortfalls, leaves a discernible legacy in today's jurisprudence, underscoring the high stakesboth for law and for social movements—of constitutional choices. 
